A Methodology for analyzing data from long-term passive acoustic monitoring

Ignacio Sánchez Gendriz 

Assinatura:

\title{
A Methodology for analyzing data from long-term passive acoustic monitoring
}

\section{Ignacio Sánchez Gendriz}

\author{
Orientador: Prof. Dr. Linilson R.Padovese
}

Doctoral dissertation submitted to the Polytechnic School - USP, in partial fulfillment of the requirements for the degree of Doctor in Science. Concentration Area: Control Engineering and Mechanics Automation.

\section{USP - Escola Politécnica}


Este exemplar foi revisado e corrigido em relação à versão original, sob responsabilidade única do autor e com a anuência de seu orientador.

São Paulo, de de

Assinatura do autor:

Assinatura do orientador:

Catalogação-na-publicação

Sánchez-Gendriz, Ignacio

A Methodology for analyzing data from long-term passive acoustic monitoring / I. Sánchez-Gendriz -- versão corr. -- São Paulo, 2017. $97 \mathrm{p}$.

Tese (Doutorado) - Escola Politécnica da Universidade de São Paulo. Departamento de Engenharia Mecânica.

1.Big Data 2.Monitoramento acústico passivo 3.Paisagem acústica submarina 4.Processamento de dados 5.Processamento digital de som I.Universidade de São Paulo. Escola Politécnica. Departamento de Engenharia Mecânica II.t. 
A mis padres, mis primeros y más amados educadores.

A mis hermanos, para quienes pretendo ser una fuente inspiradora.

A mi compañera Jane Roberta, por el amor y apoyo brindados.

A mi pequeño Antonio, especialmente a él, y al hombre en que se convertirá en el futuro. 

I would like to express my gratitude to my advisor, Prof. Linilson Padovese, who introduced me to the field of Passive Acoustic Monitoring, without his guidance and continuous support this thesis would not have been possible.

My sincere thanks also for Manuel Alberteris and Carola Cavero, two wonderful friends that welcomed me like a little brother in Brazil.

To all my professors, colleagues and friends from Brazil and Cuba who made possible that I can culminate my doctorate.

To Capes and FAPESP (2012/04785-0 and 2016/02175-0) for funding this research. 

"If you torture the data enough, nature will always confess" (Ronald Coase, Nobel Prize in Economics) 



\section{RESUMO}

SÁNCHEZ-GENDRIZ, I.. A Methodology for analyzing data from long-term passive acoustic monitoring. 2017. $97 \mathrm{f}$. Doctoral dissertation (Doctorate Candidate in Science.

Concentration Area: Control Engineering and Mechanics Automation) - Escola Politécnica (POLI/USP), São Paulo.

Apesar da ampla área dos mares brasileiros, pouco se conhece sobre paisagens acústicas submarinas no Brasil. Estas paisagens são compostas por sons de origens biológicas, geológicas e as produzidas pelo homem. As paisagens acústicas estão fortemente ligadas à dinâmica dos ecossistemas, mostrando padrões temporais diários e sazonais. Para caracterizar paisagens acústicas é necessário realizar gravações de sons por períodos de tempos prolongados, o que demanda métodos de análise inovadores. Neste sentido, a presente pesquisa visa dois objetivos principais: (1) desenvolver métodos para a análise de gravações acústicas de longa duração, (2) caracterizar a paisagem acústica do litoral do estado de São Paulo. Quatro pontos de coleta foram selecionados para monitoramento acústico passivo: um ponto situado no canal de entrada do Porto de Santos e os outros três em áreas de proteção marinhas (APM) do estado de São Paulo. Como resultado foi obtida a base de dados de sons submarinhos mais extensa dos mares brasileiros. Do ponto de vista da análise destes dados, o presente trabalho baseia-se no cálculo da Densidade Espectral de Potência, Níveis de Pressão Sonora e Espectrogramas, obtendo métodos de análise novedosos a partir técnicas tradicionais. Neste contexto a tese apresenta uma ferramenta para a visualização de dados acústicos e um método para a detecção automática de coros biológicos matutinos e vespertinos. Os resultados obtidos permitiram validar a efetividade dos métodos propostos na descrição e análise de dados acústicos de longa duração. $\mathrm{O}$ ambiente acústico nas proximidades do Porto de Santos foi dominado por ruído de embarcações, alcançando valores de níveis sonoros capazes de afetar algumas espécies de peixes e mamíferos marinhos. As paisagens acústicas dos três pontos restantes foram dominadas por coros de peixes e crustáceos, com padrões diários e sazonais (relacionados ao nascer e pôr do sol). O presente trabalho constitui a primeira pesquisa que cataloga coro de peixes e que estabelece uma referência para o estudo do ambiente acústico das regiões monitoradas. Embora os métodos apresentados usaram como estudo de caso dados de sons submarinos, a sua aplicação pode ser estendida para o monitoramento de outros ambientes aquáticos ou terrestres. Por último, a pesquisa mostra aos órgãos ambientais brasileiros que o monitoramento acústico passivo é uma ferramenta eficaz para o manejo e monitoramento de áreas protegidas e pontos de relevância econômica.

Palavras-chave: Big Data, monitoramento acústico passivo, paisagem acústica submarina, processamento de dados, processamento digital de som. 



\section{ABSTRACT}

SÁNCHEZ-GENDRIZ, I.. A Methodology for analyzing data from long-term passive acoustic monitoring. 2017. $97 \mathrm{f}$. Doctoral dissertation (Doctorate Candidate in Science.

Concentration Area: Control Engineering and Mechanics Automation) - Escola Politécnica (POLI/USP), São Paulo.

Despite the extensive Brazilian coast areas, little is known on underwater acoustic environments in Brazil. Acoustic environments (or soundscape) are composed by biological, geological and man-made sound sources. Soundscapes are strongly linked to ecosystems dynamics, and follow temporal patters that can vary at daily and seasonal scales. Thus, for soundscape characterization, it is necessary to undertake sound recordings for long periods, which demands innovative analyzing methods. Accordingly, the present research focuses in two principal objectives: (1) to develop methods for analyzing long-term acoustic recordings and, (2) to characterize marine soundscapes of selected points in Sao Paulo State. Four deployment sites were selected for the underwater acoustic monitoring: a point located at the channel entrance of the Santos Harbor, and three marine Protected Areas (PAs) in Sao Paulo state. As a result, the largest underwater acoustic database from Brazilian seas was acquired. The present work used Power Spectral Density (PSD), Sound Pressure Level (SPL) and Spectrograms to develop an innovative methodology for analyzing long-term acoustic data. In addition, a new visualization tool and a method for automatic detection of dawn and dusk choruses are presented. The achieved results validated the proposed methodology as an effective tool for analyzing long-term acoustic data. The area close to the first site, the vicinity of Santos Harbor, was dominated by ship noise, which values reach levels that can affect some species of fish and marine mammals. The soundscapes of the other three remaining measurement sites were dominated by fish and crustacean choruses, with daily and seasonal patterns (related to sunrise and sunset). For the monitored regions, the present work signifies the first contribution for cataloguing fish choruses, and establishes a baseline for the study of their underwater acoustic environment. Although the proposed methodology has used long-term undersea acoustic datasets as case-study, it can also be extended for monitoring other aquatic or terrestrial ecosystems. Finally, the research indicates to Brazilian environmental agencies and to the related scientific community that passive acoustic monitoring is a noninvasive and cost-effective tool that can be used for the management of PAs and points of economic relevance.

Key-words: Big Data, passive acoustic monitoring, soundscape, data processing, digital son processing. 



\section{RESUMEN}

SÁNCHEZ-GENDRIZ, I.. A Methodology for analyzing data from long-term passive acoustic monitoring. 2017. 97 f. Doctoral dissertation (Doctorate Candidate in Science.

Concentration Area: Control Engineering and Mechanics Automation) - Escola Politécnica (POLI/USP), São Paulo.

A pesar de la amplia área de los mares brasileños, poco se conoce sobre ambientes acústicos submarinos en Brasil. Los ambientes (o paisajes) acústicos están compuestos por sonidos de orígenes biológicos, geológicos e producidos por el hombre. Los paisajes acústicos están fuertemente ligados a la dinámica de los ecosistemas, mostrando padrones temporales diarios y estacionales. Para caracterizar los paisajes acústicos, es por tanto necesario realizar grabaciones sonoras por períodos de tiempos prolongados, lo que demanda métodos de análisis inovadores. En ese sentido, la presente investigación aspira dos objetivos principales: (1) desarrollar métodos para el análisis de grabaciones acústicas de larga duración, (2) caracterizar el ambiente acústico de puntos de interés estratégico en el estado de São Paulo. Cuatro puntos de colecta fueron seleccionados para la monitorización acústica pasiva: un punto situado en el canal de entrada del Puerto de Santos y tres áreas de protección marinas (APM) del estado de São Paulo. Como resultado fue adquirida la base de datos de sonidos submarinos más extensa de los mares brasileños. Desde el punto de vista da análisis de estos datos, el presente trabajo se fundamenta en el cálculo de la Densidad Espectral de Potencia, Niveles de Presión Sonora e Espectrogramas, obteniendo una metodología inovadora a partir de técnicas tradicionales. También son presentados una herramienta para la visualización y un método para la detección automática de coros biológicos matutinos e vespertinos. Los resultados obtenidos permitieron validar la efectividad de los métodos propuestos para la descripción e el análisis datos aústicos de larga duración. El ambiente acústico en las proximidades del Puerto de Santos estuvo dominado por ruido de embarcaciones, alcanzando valores de niveles sonoros capaces de afectar algunas especies de peces e mamíferos marinos. Los ambientes acústicos de los restantes tres puntos de medición estuvieron dominados por coros de peces y crustáceos, con padrones diarios e estacionales (relacionados al nascer y puesta del sol). El presente trabajo constituye la primera investigación que cataloga coro de peces y que establece una referencia para el estudio del ambiente acústico en las regiones estudiadas. Aunque la metodología presentada usó como caso de estudio datos de sonidos submarinos, su aplicación puede ser extendida para el estudio de otros ambientes acuíferos o terrestres. Por último, la investigación muestra a los órganos ambientales brasileños que el estudio acústico pasivo es una herramienta eficaz para el gerenciamiento de áreas protegidas y para la monitorización de puntos de relevancia económica.

Palabras clave: Big Data, monitorización acústica pasiva, paisaje acústico submarino, procesamiento de datos, procesamiento digital de sonido. 

Figure 1 - OceanBase cabled system, developed at LADIN . . . . . . . . . . . 30

Figure 2 - OceanPod autonomous system, developed at LADIN . . . . . . . . . . 30

Figure 3 - Some applications of daily Pxx matrices. . . . . . . . . . . . 33

Figure 4 - Flowchart of daily Pxx matrices calculation. . . . . . . . . . . 33

Figure 5 - Nominal ship noise frequency band displayed with frequency band of sounds emitted by several species. Font: (GÖTZ et al., 2009)). . . . . . . . . . . . 36

Figure 6 - Hidrophone locatated at Ilha das Palmas, Santos Bay, São Paulo State, Brazil. 37

Figure 7 - Spectrogram of underwater sounds collected from October 11 to October 21, 2013, at Ilha das Palmas. Energy concentration below $1 \mathrm{kHz}$ is related to ship noise, nocturnal sound events appear slightly above $1 \mathrm{kHz}$ and are related to fish choruses. . . . . . . . . . . . . . . . . . . . . .

Figure 8 - Mean PSD calculated from of underwater sounds collected from October 11 to October 21, 2013, at Ilha das Palmas. a) Daily mean PSD and b) total mean PSD. . . . . . . . . . . . . . . .

Figure 9 - Mean PSD calculated from of underwater sounds collected from October 11 to October 21, 2013, at Ilha das Palmas. Mean $P S D^{1}$ was calculated excluding fish chorus periods for each day. . . . . . . . . . . . . . .

Figure 10 - Box plot representation of SPL in full frequency band for underwater sounds collected at Ilha das Palmas, from Periods I and II.

Figure 11 - Power Spectral density percentiles $1^{\text {st }}, 5^{\text {th }}, 50^{\text {th }}, 95^{\text {th }}$ and $99^{\text {th }}$ for underwater sounds collected at Ilha das Palmas, a) Period I and b) Period II. . . . . . . . 41

Figure 12 - Box plot from SPL in the selected 1/3 octave bands: $80 \mathrm{~Hz}, 100 \mathrm{~Hz}, 125 \mathrm{~Hz}$, $200 \mathrm{~Hz}$ and $250 \mathrm{~Hz}$, a) from Period I and b) from Period II. . . . . . . . . . 42

Figure 13 - XJSP (Santos Bay) and LSMSP localization. . . . . . . . . . . . . . . 47

Figure 14 - Example of a Seven-day spectrogram from February 18 to February 24, 2015, (integration time $\mathrm{T}=60 \mathrm{~s}$ ), a) LSMSP and b) XJSP. . . . . . . . . . . .

Figure 15 - 24-h spectrogram for February 22, 2015, (integration time $\mathrm{T}=60 \mathrm{~s}$ ), a) LSMSP and b) XJSP. . . . . . . . . . . . . . . . . . . 49

Figure 16 - 24-h Mean spectrogram, (integration time T= $60 \mathrm{~s}$ ), a) LSMSP and b) XJSP. 50

Figure 17 - Daily averaged FFB SPL. . . . . . . . . . . . . . . 51

Figure 18 - Four day spectrogram from August 20 to 23, 2005 at the coast of southern New Jersey, USA (MANN; GROTHUES, 2009). . . . . . . . . . . . . . . . 52 
Figure 19 - Three days spectrogram that shows chorus from fishes of the Sciaenid family during the passage of a hurricane in Charlotte Harbor, Florida (LOCASCIO; MANN, 2005). . . . . . . . . . . . . . . . . . 52

Figure 20 - Spectrogram of unidentified fish calls (integration time $\mathrm{T}=0.30 \mathrm{~s}$ ), a) sound in the vicinity of event $X_{2}$, b) sound in the vicinity of event $X_{4} \ldots \ldots$. .

Figure 21 - Power Spectral density $1^{s t}, 5^{t h}, 50^{t h}, 95^{t h}, 99^{t h}$ and mean percentiles, a) LSMSP and b) XJSP. . . . . . . . . . . . . . . . 54

Figure 22 - Boxplot of FFB SPL of underwater sounds recorded from February 2 to March 1, 2015 for LSMSP and XJSP. . . . . . . . . . . . . . . . . . 55

Figure 23 - Ship traffic density related to Santos port, São Paulo, Brazil. . . . . . . . . . 55

Figure 24 - 24-h mean spectrogram highlighting predominant acoustic events at studied PAs a) LSMSP and b) XJSP. . . . . . . . . . . . . . . . . . . . .

Figure 25 - Discontinuous line represents 24-h SPL curve for February 7, 2015 in XJSP; continuous line represents the smoothed 24-h SPL . . . . . . . . . . . 60

Figure 26 - Example of manual annotations of start (blue), peak (black) and end (green) of chorus XJ 2 type based on spectrogram and SPL in the frequency band: $0.3-1.5 \mathrm{kHz} . \ldots \ldots \ldots \ldots \ldots \ldots$

Figure 27 - PSD of example sections of a fish chorus recorded in Australia; b) waveforms and expanded waveforms of the calls for chorus represented in a). Modified from (PARSONS et al., 2016a). . . . . . . . . . . . . . . . .

Figure 28 - a) Variation of start time for each chorus type and b) variations of end time for each chorus type. . . . . . . . . . . . . .

Figure 29 - a) Variation in peak occurrence time for each chorus type and b) dispersion of chorus time instants points. . . . . . . . . . . . 63

Figure 30 - a) Duration for each chorus types and b) variation in dominant frequencies. .

Figure 31 - Mean PSD of a representative time slice of each chorus type from a randomly selected day. The highlighted point represents the dominant frequency for the respective chorus type. The exception is for c) where dominant frequency for $X J_{2}$ appears in green, and for $X J_{3}$ in black. . . . . . . . . . . . .

Figure 32 - 24-h mean spectrogram representing start, peak and end time instants of chorus over dominant frequency mean values, a) LSMSP and b) XJSP. . . . 65

Figure 33 - Alcatrazes island localization and hidrophone position (circular marker). . . 71

Figure 34 - Representation of SPL curve converted as color-map bar; a) Low-FB SPL calculated for May $6^{\text {th }}, 2016$; b) The color-map bar referent to Low-FB SPL in a); c) range of used colors and their respective range of SPL values for this particular example. . . . . . . . . . . . . 
Figure 35 - Representation of the procedure used to detect dawn and dusk chorus activities, a) determination of the search space over median Low-FB SPL curve for dusk chorus activity detection, b) an example of determination of dusk timing indicator by both MaxAT $\left(P_{\text {MaxAT }}\right)$ and LoMAX $\left(P_{\text {LoMAX }}\right)$ methods. .

Figure 36 - SPL in selected frequency bands calculated for underwater sounds recorded at Alcatrazez Wildlife Refuge from March $7^{\text {th }}$ to June $7^{\text {th }}$, a) Low-FB SPL: 0

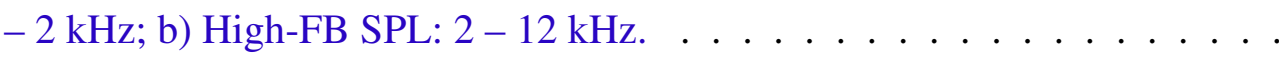

Figure 37 - SPL in selected frequency bands calculated for underwater sounds recorded at Alcatrazez Wildlife Refuge from April $10^{\text {th }}$ to April $12^{\text {th }}$, a) Low-FB SPL: $0-2 \mathrm{kHz}$; b) High-FB SPL: $2-12 \mathrm{kHz}$. Dashed red lines indicate the sunrise and sunset, the red points represents daily peaks. . . . . . . . . . 76

Figure 38 - SPL grouped by frequency bands and moon types. . . . . . . . . . . . . 76

Figure 39 - Average soundscape summarization for May $8^{\text {th }}$ June $7^{\text {th }}$; a) mean 24 - $\mathrm{h}$ spectrogram, b) mean 24-h Low-FB SPL, c) mean 24-h High-FB SPL. . . .

Figure 40 - Average soundscape summarization for March $7^{\text {th }}-$ April $6^{\text {th }}$; a) median 24 - h spectrogram, b) median 24-h Low-FB SPL, c) median 24-h High-FB SPL. 78

Figure 41 - Average soundscape summarization for April $7^{\text {th }}$ - May $7^{\text {th }}$; a) median 24 h spectrogram, b) median 24-h Low-FB SPL, c) median 24-h High-FB SPL.

Figure 42 - Average soundscape summarization for May $8^{\text {th }}$ - June $7^{\text {th }}$; a) median 24 - $\mathrm{h}$ spectrogram, b) median 24-h Low-FB SPL, c) median 24-h High-FB SPL. .

Figure 43 - Adjusted values of detected dawn and dusk chorus "timing" plotted over sunrise and sunset; a) dawn choruses detected in Low-FB, b) dawn choruses detected in High-FB, c) dusk choruses detected in Low-FB, b) dusk choruses detected in High -FB. . . . . . . . . . . . . . . . . . .

Figure 44 - SPL-gram images in the selected frequency bands. Traced lines represent sunrise and sunset and marker points indicate the dawn and dusk chorus activities detected by MaxAT method, a) Low-FB SPL-gram and b) High-FB SPL-gram. . . . . . . . . . . . . . . . .

Figure 45 - 24-h spectrogram from July $2^{\text {nd }}, 2016$; the sunrise and sunset time occurrence are indicated by traced lines. Tow prominent biological sounds types can be highlighted below $1 \mathrm{kHz}$ : between $00 \mathrm{~h}-09 \mathrm{~h}$ and $11 \mathrm{~h}-12 \mathrm{~h} \mathrm{HW}$ sounds, and between $15 \mathrm{~h}-22 \mathrm{~h}$ fish choruses. . . . . . . . . . . . .

Figure 46 - Spectrogram of 30 seconds of underwater sounds recorded Alcatrazes on July $2^{\text {nd }}$. The demarcated rectangular areas contain HW sounds, Crustaceus biological Noise $(\mathrm{CN})$ examples are also annotated. . . . . . . . . . . . . 

Table 1 - Statistics from SPL, SEL, m-meighted SEL $\left(S E L_{W_{I}}, S E L_{W_{I I}}, S E L_{W_{I I I}}\right.$ and

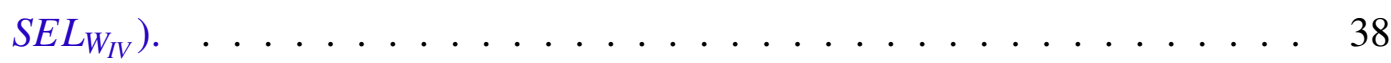

Table 2 - Ratios between power concentrations within frequency bands of interest, SFB: $10 \mathrm{~Hz}$ - 1 kHz, LFB: 25 - $290 \mathrm{~Hz}$, NSFB: 1 - 8 kHz, FFB: $10 \mathrm{~Hz}-8 \mathrm{kHz}$. . 40

Table 3 - Median and its difference for SPL in selected 1/3 octave bands for the two Periods. . . . . . . . . . . . . . . . . . . . 42

Table 4 - Description of time frequency patterns of principal acoustics events in LSMSP and XJSP . . . . . . . . . . . . . . . . . . . . . 51

Table 5 - Representative values of SPL variability. . . . . . . . . . . . . 55

Table 6 - Statistics for chorus characteristics. . . . . . . . . . . . . . 65

Table 7 - Time (h UTC) of highest peaks near sunrise $\left(P e a k_{s r}\right)$ and sunset $\left(P e a k_{s s}\right)$ in median average SPL by frequency bands. Denoted by red points in Figures 40,41 and $42 \ldots \ldots \ldots \ldots$. . . . . . . . . . . . . . . . . . . . . . . . . . . . . . .

Table 8 - Standard deviation in minutes for detected values of chorus timing. . . . . 80

Table 9 - Days with HW sounds detected by spectrogram and listening inspection. . . 84 



\section{LIST OF ABBREVIATIONS AND ACRONYMS}

$F_{0} \ldots \ldots$ Pulse repetition frequency

$p_{\text {ref }} \ldots . .$. Reference pressure underwater

$\mathrm{dB} \ldots . .$. decibel

DF ...... Dominant Frequency

FFB ..... Full Frequency Band

High-FB .. High Frequency Band

HW ..... Humpback whales

LoMAX .. Local maximum method

Low-FB .. Low frequency Band

LSMSP ... Laje de Santos Marine State Park

MaxAT ... Maximal Area Triangulation method

NSFB .... Frequency Bandwidth out of Ship noise Frequency Bandwidth

PAM .... Passive Acoustic Monitoring

PAs ...... Protected Areas

PSD ...... Power Spectral Density

SEL ..... Sound Exposure Level

SFB ..... Ship noise Frequency Bandwidth

SPL ...... Sound Pressure Level

$\mathrm{T} \ldots \ldots$ Integration Time

XJSP .... Xixová-Japuí State Park 


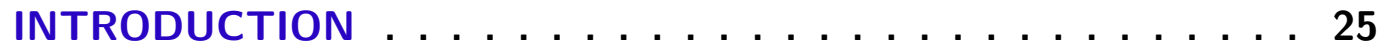

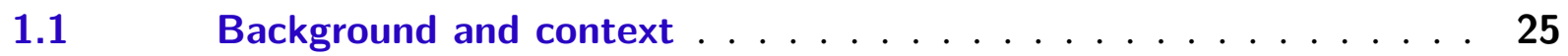

1.2 Research aims . . . . . . . . . . . . . . . . . 26

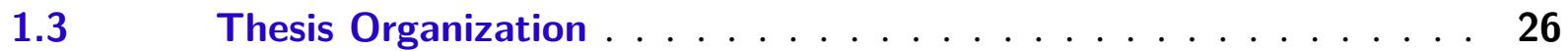

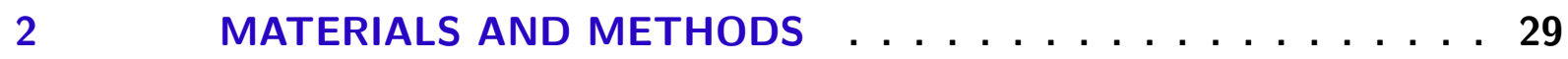

$2.1 \quad$ Monitoring systems used in the present study . . . . . . . . . 29

2.1.1 OceanBase cabled system . . . . . . . . . . . . . . . . 29

2.1.2 OceanPod autonomous system . . . . . . . . . . . . . . 29

$2.2 \quad$ Standard metrics for characterization of acoustic habitats . . . . 30

$2.3 \quad$ Numerical calculations . . . . . . . . . . . . . . . . . . 32

2.4 Daily Pxx matrices, 24-h Spectrograms and 24-h SPL . . . . . . 32

$2.5 \quad$ Monitored points . . . . . . . . . . . . . . . 34

3 SOUND LEVEL ESTIMATION FOR ASSESSMENT OF UNDERWATER SHIP NOISE . . . . . . . . . . . . . . 35

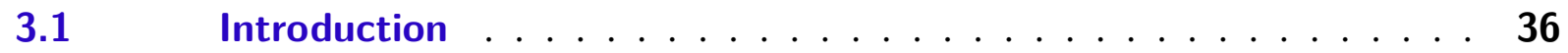

$3.2 \quad$ Materials and methods . . . . . . . . . . . . . . 37

3.2.1 Passive acoustic monitoring (system) and Deployment site . . . . 37

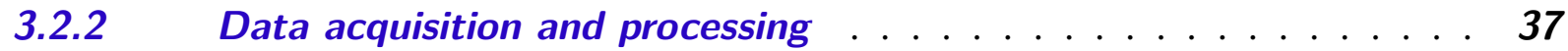

$3.3 \quad$ Results and discussion $\ldots \ldots \ldots \ldots \ldots \ldots$

3.3.1 Estimating ship contribution to total noise . . . . . . . . 38

3.3.2 Comparisons between two different periods. . . . . . . . . . . . 40

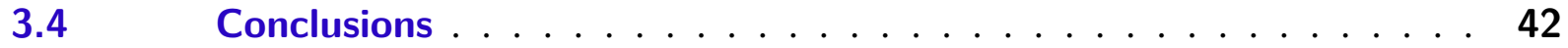

4 UNDERWATER SOUNDSCAPE OF MARINE PROTECTED AREAS IN THE SOUTH BRAZILIAN COAST . . . . . . . . . . . 45

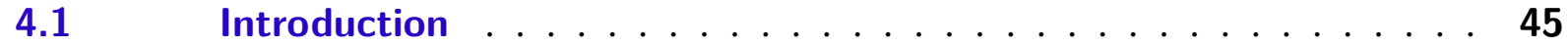

4.1.1 Marine protected areas close to Santos Bay . . . . . . . . . . 46

4.1.2 Xixová-Japuí State Park . . . . . . . . . . . . . . . . . 46

4.1.3 Previous studies and objectives . . . . . . . . . . . . . 46

$4.2 \quad$ Methodology . . . . . . . . . . . . . . . . . 47

4.2.1 Autonomous passive monitoring system and its deployment . . . . 47

4.2.2 Data processing . . . . . . . . . . . . . . . . . . 48 
4.2.2.1 Spectrogram representation . . . . . . . . . . . . . . . 48

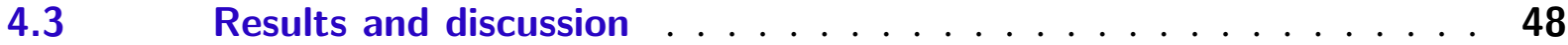

4.3.1 Periodic events and spectral characterization . . . . . . . . . . 48

4.3.2 PSD percentiles and frequency characterization . . . . . . . . . . 54

4.3.3 SPL values and anthropogenic activities . . . . . . . . . . . 54

$4.4 \quad$ Conclusions . . . . . . . . . . . . . . . . . . 56

5 TEMPORAL AND SPECTRAL PATTERNS OF FISH CHORUSES

IN TWO PROTECTED AREAS IN SOUTHERN ATLANTIC . . . . 57

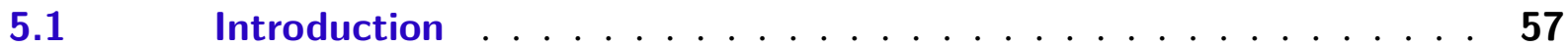

$5.2 \quad$ Materials and methods . . . . . . . . . . . . . 59

$5.2 .1 \quad S P L$ smoothing . . . . . . . . . . . . . . 59

5.2.2 Manual detection of chorus occurrence times . . . . . . . . . . . 60

5.2.3 Cepstral analysis for striped chorus type . . . . . . . . . . . . . . 60

5.2.4 Statistical analysis of chorus characteristics . . . . . . . . . . . 62

$5.3 \quad$ Results ....................... 62

5.3.1 Spectral analysis ................... 63

$5.4 \quad$ Discussion . . . . . . . . . . . . . . . . 65

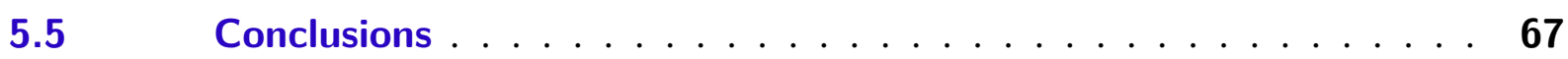

6 ANALYZING BIOLOGICAL CHORUSES FROM LONG-TERM PASSIVE ACOUSTIC MONITORING IN NATURAL AREAS . . . . . . 69

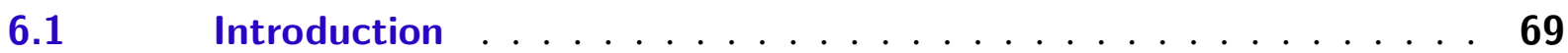

6.1.1 Soundscape ecology, a relevant property of ecosystems . . . . . . 69

6.1.2 The challenge of summarizing and visualizing large acoustic datasets 70

6.1.3 Dataset used as case study: 3 months of continuous recordings in a marine wildlife refuge . . . . . . . . . . . . . . . . . 70

$6.2 \quad$ Materials and Methods . . . . . . . . . . . . . 71

6.2.1 The passive monitoring system and its deployment . . . . . . . . 71

6.2.2 Data analysis . . . . . . . . . . . . . . . . . . 71

6.2.2.1 Selection of frequency bands for SPL calculation . . . . . . . . . . . . 72

6.2.2.2 Averaging daily records . . . . . . . . . . . . . . . 72

6.2.2.3 SPL in frequency bands and its representation as SPL-gram images . . . . 72

6.2.2.4 Automatic detection of dawn and dusk chorus activities . . . . . . . . . . . 73

$6.3 \quad$ Results and discussion . . . . . . . . . . . . . 74

6.3.1 SPL series in low and high frequency bands . . . . . . . . . . . 74

6.3.2 Averaging 24-h Spectrograms and 24-h SPL . . . . . . . . . . . 76

6.3.3 Detection of dawn and dusk chorus activities . . . . . . . . . . 80

6.3.4 SPL-gram image summarization . . . . . . . . . . . . . 81

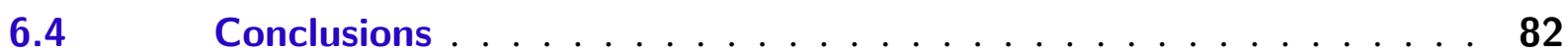


FIRST RECORDS OF HUMPBACK WHALE SOUNDS FROM SAO PAULO LONG-TERM PASSIVE ACOUSTIC MONITORING . . . . 83

8 OVERALL CONCLUSIONS ................ 87

BIBLIOGRAPHY ........................ 89 


\subsection{Background and context}

Nowadays, the use of passive acoustic to monitor environments during long periods is an area of growing research (TOWSEY; PARSONS; SUEUR, 2014). Sounds convey relevant information related to the functioning and dynamics of ecosystems (PIJANOWSKI et al., 2011a; SUEUR; FARINA, 2015; PIERETTI et al., 2015)

The topic of animal sound communications, included in the field of bioacoustics, has been studied for decades (ELDRIDGE et al., 2016; TOWSEY et al., 2014b), and still is an area of active research (MARQUES et al., 2014). Bioacoustics is a discipline related to species behavior, which focuses on sounds emitted by individuals and the information transmitted among them (MARQUES et al., 2014; SUEUR; FARINA, 2015).

Beyond aiming to study individual animal communications, the emerging field of Soundscape Ecology (PIJANOWSKI et al., 2011b; PIJANOWSKI et al., 2011a) considers the hole collection of sounds that emanate from environments. Soundscape include biological noises (biophony), geological noises (geophony), and anthropogenic noises (anthropophony), being a fundamental component that can reflect important ecosystem process (STAATERMAN et al., 2014; SUEUR; FARINA, 2015; TOWSEY et al., 2014a)

In order to characterize the soundscape from natural environments it is necessary to carry out acoustic monitoring from long periods, since environmental sounds can follow temporal patters that vary at daily and seasonal scales (GAGE; AXEL, 2014). Nowadays, passive acoustic monitoring (PAM) systems allow collecting sounds for several months or even continuously, which implies a need to deal with terabytes of data (TOWSEY; PARSONS; SUEUR, 2014). Thus, new methods to highlight, visualize and summarize the relevant information of such massive amount of data are required.

Also, it is worth noting that no detailed research had been focused on long-term monitor- 
ing of marine soundscape in Brazilian oceans. Aiming to cover this gap of information, through the development of the present research, underwater sound recordings were undertaken in four selected points on the Sao Paulo coast:

- Ilha das Palmas, a point located in the entrance of the port of Santos channel, the biggest and busiest port in Latin America.

- Xixova-Japuí State Park, a protected park inside an area severely affected by environmental impacts, particularly unplanned urban settlement, industrialization and related port activities.

- Laje de Santos Marine State Park.

- Alcatrazes Wildlife Refuge.

The last two points represent important marine protected areas that hold a variety of fishes, algae and turtles, and also cetaceans.

The related acoustic datasets constitute the first underwater acoustic monitoring of the studied sites.

The objectives of this research are related to the abovementioned topics, and are listed in section 1.2.

\subsection{Research aims}

- To establish a reference for noise levels in the neighborhood of the port of Santos and to estimate the contribution of ship noise in this area.

- To characterize the soundscape of marine protected areas on Sao Paulo coast, focusing on the temporal and spectral patterns of biological choruses, key acoustic components of natural environments.

- To develop a method for detecting daily and seasonal variations in large acoustic monitoring data.

- To develop a method for summarizing and visualizing large acoustic datasets from longterm acoustic monitoring.

\subsection{Thesis Organization}

Six manuscripts, written during the development of the $\mathrm{PhD}$ research, form the core of the present thesis. Two of the papers (SANCHEZ-GENDRIZ; PADOVESE, 2014; SANCHEZGENDRIZ; PADOVESE, 2015) were presented in IEEE International Congress, two others were 
published (SANCHEZ-GENDRIZ; PADOVESE, 2016; SANCHEZ-GENDRIZ; PADOVESE, 2017) in internacional journals and the remaining two were submitted for publication.

Chapter 2 is a general description of the basic of materials and methods used throughout the text. When necessary, particularities will be detailed in specific chapters.

Chapter 3 describes the methods used to quantify the shipping noise contribution to the total ambient noise at the port of Santos area. This chapter also compares shipping noise for different seasons in this important area.

Chapter 4 explores the use of 24-h mean spectrogram to summarize large scale acoustic data. It also presents for first time, an underwater soundscape characterization of Laje de Santos Marine State Park and Xixova-Japui State Park.

Chapter 5 concerns to a detailed description of temporal and spectral patterns of biological choruses detected in the soundscapes presented in chapter 4.

Chapter 6 shows a new representation used to summarize and visualize long-term acoustic data, the SPL-Gram, as well as a method for automatic detection of acoustic activity of dawn and dusk choruses.

Finally, Chapter 7 illustrates how the uses of daily 24-h spectrogram can be used as a simple exploratory tool to detect the presence of humpback whales in long-term acoustic datasets. The results presented in this chapter are the first reports of humpback whale sound recorded in long-term monitoring in São Paulo waters. 



\section{MATERIALS AND METHODS}

This chapter explains the fundamentals of the materials ans methods used in the text; specific details are described when needed in the subsequent chapters.

\subsection{Monitoring systems used in the present study}

Tow PAM systems were emploied for collecting the underwater sound data in the present study. Both systems were developed at the Laboratory of Dynamics and Instrumentation (LADIN) of the Politechnic School of the University of São Paulo, the particularities of these systems are described below.

\subsubsection{OceanBase cabled system}

The system comprises a hydrophone (a) that can be moored to a platform located on the seabed. The hydrophone was linked by a cable (b) to an acquisition unit (c) in land, which allowed data storage and remote control through an Ethernet connection. Figure 1 illustrates the parts that constitute the OceanBase. A headphone can be connected to the acquisition unit at any time to test if the system is functioning properly.

\subsubsection{OceanPod autonomous system}

The OceanPod is an autonomous system that comprises a hydrophone, an acquisition unit, a battery pack, and a PVC enclosure (Figure 2). The hydrophone and its stainless steel protection are mounted on the outer top surface of the PVC enclosure. The remaining components are situated inside a cylindrical PVC enclosure, which can be submerged to a depth of $300 \mathrm{~m}$ approximately. 


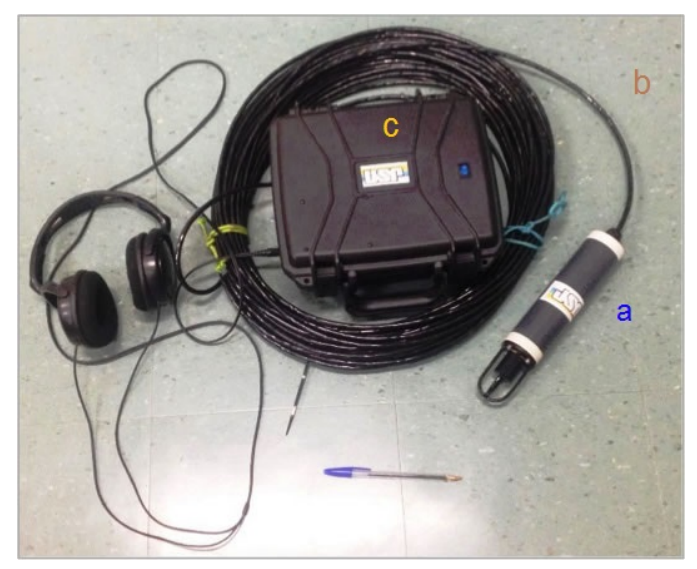

Figure 1 - OceanBase cabled system, developed at LADIN.

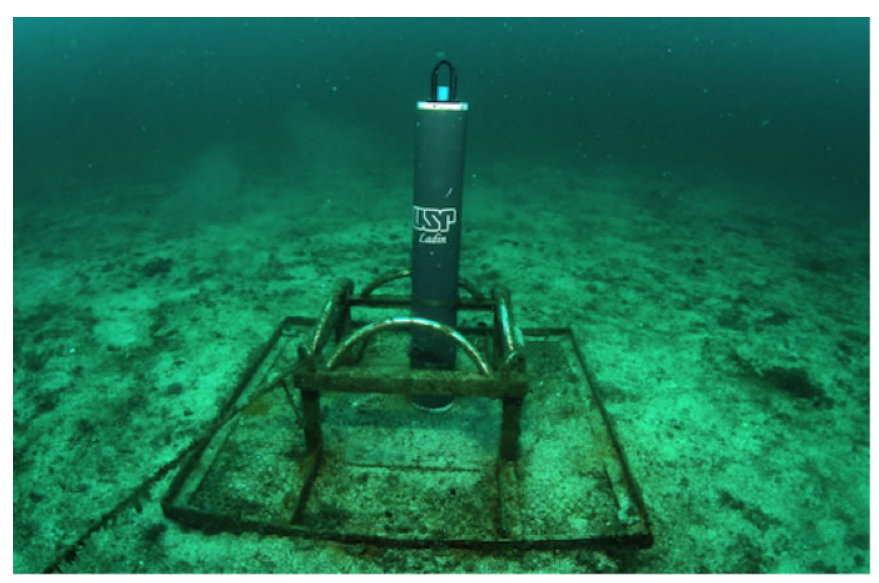

Figure 2 - OceanPod autonomous system, developed at LADIN.

\subsection{Standard metrics for characterization of acoustic habi- tats}

There are several metrics that could be considered for underwater acoustic measurements. Particularly, Sound Pressure Level (SPL), Sound Exposure Level (SEL) and Power Spectral Density (PSD) are quantities commonly employed for this purpose (ERBE, 2011; TNO, 2011; MERCHANT et al., 2012). They are defined as:

1) Sound Pressure Level

SPL is the Mean Square Pressure (MSP) expressed in decibel (dB) relative to a reference pressure $\left(p_{r e f}\right)$ for sound in water (TNO, 2011; MERCHANT et al., 2012), as illustrated in expression 2.1:

$$
S P L=10 \log _{10} \frac{M S P}{p_{r e f}^{2}} \quad\left[\begin{array}{lll}
d B & \text { re } & 1 \mu P a^{2}
\end{array}\right]
$$


Where $p_{\text {ref }}=1 \mu \mathrm{Pa}($ MERCHANT et al., 2015) and MSP (TNO, 2011) can be determined by 2.2:

$$
M S P=\frac{1}{T} \int_{0}^{T} p(t)^{2} d t
$$

Being $\mathrm{T}$ the integration time and $\mathrm{p}(\mathrm{t})$, the sound pressure at instant $\mathrm{t}$.

SPL is a suitable metric for ambient noise analysis (ROBINSON; LEPPER; HAZELWOOD, 2014), and SPL 1/3 octave bands (TNO, 2011) can be used to estimate the contribution of an specific frequency band to the total ambient noise.

2) Sound Exposure Level, M-weightings and Weighted SEL

SEL is a measure of the sound energy (MERCHANT et al., 2012). It allows comparing the energy emitted by acoustic signals of different duration 2.3:

$$
S E L=S P L+10 \log _{10} T \quad\left[d B \text { re } 1 \mu P a^{2} s\right]
$$

In general, animals do not perceive sound equally well at all frequencies within their functional hearing range and, besides, the hearing range differs among species groups. For marine mammals, four functional hearing groups in water have been established (I: low-frequency cetaceans, II: mid frequency cetaceans, III: high-frequency cetaceans, and IV: pinnipeds). These groups may be differently affected even by identical sound exposure (SOUTHALL et al., 2007), and therefore frequency weighting functions are required to develop a marine mammal noise exposure criterion.

M-weighting functions $\left(W_{l}\right)$ are frequency-weighting functions that allow to adjust the sensitivity of the four hearing groups to sound exposure in water (SOUTHALL et al., 2007). They can be applied to SEL to obtain an indicator (weighted SEL) of the impact of underwater noise on marine mammals.

3) Power Spectral Density (PSD)

PSD is the contribution of the power per unit of bandwidth (PROAKIS; MANOLAKIS, 2007). PSD matrices were calculated for recorded audio files by means of the Welch's method (WELCH, 1967). These matrices were named $\operatorname{Pxx}(\mathrm{n}, \mathrm{m}), \mathrm{n}$ and $\mathrm{m}$ indicating time and frequency indexes respectively. The use of Pxx matrices are detailed in section 2.4.

4) Percentiles

The $n^{\text {th }}$ percentile indicates the level below which $\mathrm{n}$ percentage of observations fall, in a group of observations(DECOURSEY, 2003; VERFUS et al., 2014). In particular, the $50^{\text {th }}$ percentile is also known as median. The percentile could be used to summarize noise levels in frequency or in time domain (HARRIS; SHEARS; RADFORD, 2016).

5) Box plot representations of SPL 
The statistical representation of box plot (DECOURSEY, 2003; VELLEMAN; HOAGLIN, 1981) can be used to point up the SPL variability in the recorded full frequency band and SPL $1 / 3$ octave bands. For this representation the boxes show the median, and percentiles $25^{\text {th }}\left(q_{1}\right)$ and $75^{\text {th }}\left(q_{3}\right)$. The values not considered outliers are within the upper and lower limits $V_{1}$ and $V_{2}$, where $V_{1}=q_{1}+w\left(q_{3}-q_{1}\right), V_{2}=q_{1}-w\left(q_{3}-q_{1}\right)$. The parameter $w$ was set to 1.5 for the boxplot figures in this text, in this case the values between $V_{1}$ and $V_{2}$ cover $99.3 \%$ of the data if it is normally distributed. When appear the '+' symbols in boxplot graphics, it will represent outlier values.

\subsection{Numerical calculations}

1) MSP and weighted MSP

Due to the discrete nature of data, 2.2 can be computed by the numerical approximation 2.4:

$$
M S P=\frac{1}{N} \sum p^{2}(j)
$$

Expression 2.4 works in time domain, but based on Parsevals relation (PROAKIS; MANOLAKIS, 2007), it is possible to make this computation in frequency domain, as in 2.5:

$$
M S P=\frac{1}{k} \sum_{n=k i+1}^{k(i+1)} \sum_{m=f_{1}}^{f_{2}} P_{x x}(n, m)
$$

Where $\mathrm{i}=0,1,2 \ldots$ until the time indices of Pxx allow, and $\mathrm{k}=\mathrm{T} / T_{1}$, in which $\mathrm{T}$ is the integration time and $T_{1}$ (the time length of windows used in PSD calculations). $f_{1}$ and $f_{2}$ are respectively the low and high frequencies in a selected bandwidth. The weighted MSP for the four hearing groups (that is, $M S P_{w k}$ ) was estimated based in (TNO, 2011), as (6) shows:

$$
M S P_{w l}=\frac{1}{k} \sum_{n=k i+1}^{k(i+1)} \sum_{m=f_{1}}^{f_{2}} W_{l} P_{x x}(n, m)
$$

Where $W_{l}$ (m- weighted functions) are quantities relating the hearing group 1 , for $1=\mathrm{I}$, II, III or IV, as detailed before.

\subsection{Daily Pxx matrices, 24-h Spectrograms and 24-h SPL}

As it can be seen from section 2.3, the Pxx matrices can be used as fundamental blocks to calculate metrics which are relevant to characterize acoustic environments, such as SPL and SEL. Particularly, daily Pxx matrices constitutes the main unit of analysis of the methodologies throughout the text. Some of the principal uses of these matrices are illustrated in Figure 3. 


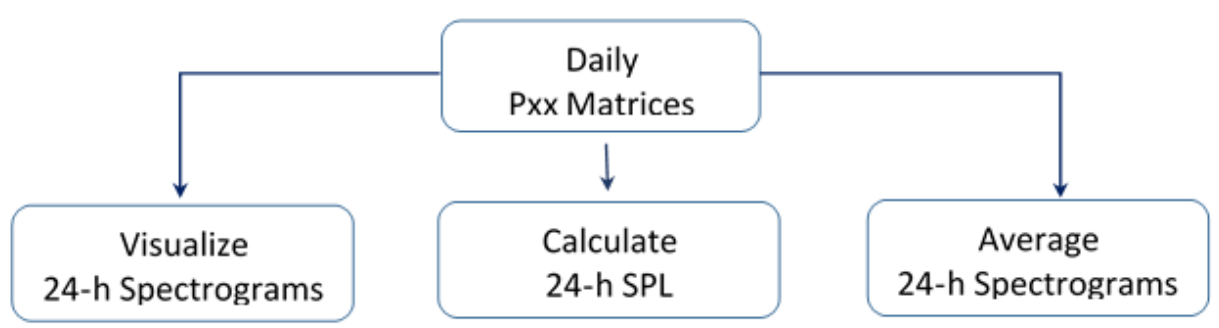

Figure 3 - Some applications of daily Pxx matrices.

The procedure used to determine daily Pxx matrices is represented as a flowchart in Figure 4, which can be explained as two nested for loops. The first loop is used to calculated the PSD matrix (pxx) respective to each wav file, and runs for $\mathrm{i}=1,2, \ldots, M_{k}$; where $M_{k}$ represents the number of wav files recorded for day $\mathrm{k}$. The second loop is used to merge all $p x x_{i, k}$ matrices into a daily $P x x_{k}$, and runs for $\mathrm{k}=1,2, \ldots, \mathrm{N}$; where $\mathrm{N}$ represents the number of days to be analyzed.

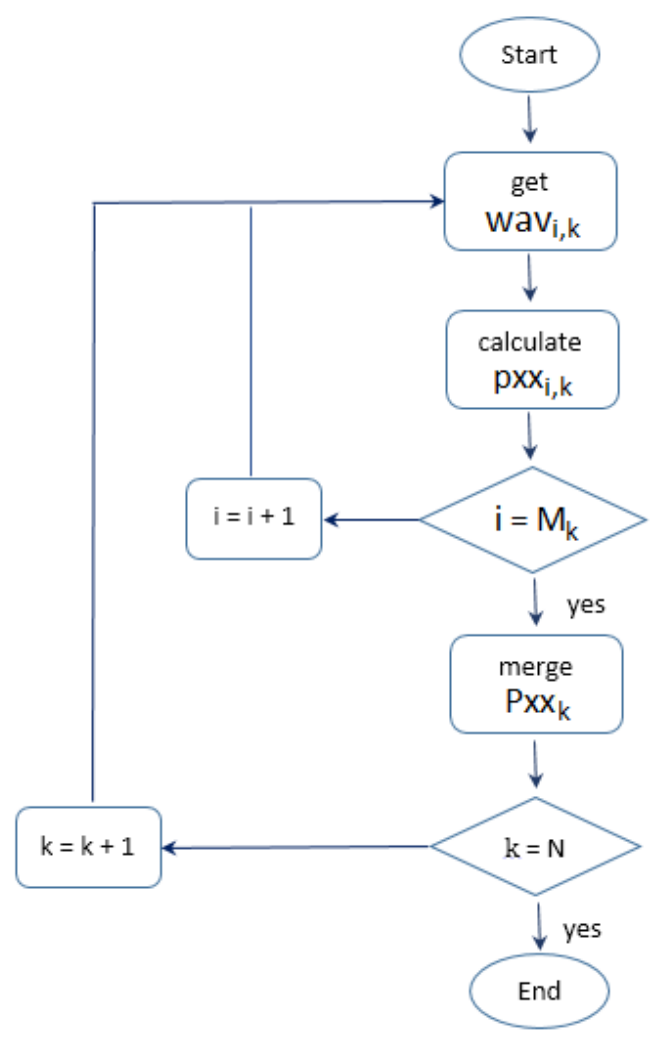

Figure 4 - Flowchart of daily Pxx matrices calculation. 


\subsection{Monitored points}

The underwater acoustic datasets analyzed during the research development were collected in four points of Sao Paulo State coast. These points are listed below and are detailed in following chapters.

1. Ilha das Palmas

2. Xixova-Japui State Park

3. Laje de Santos Marine State Park

4. Alcatrazes Wildlife Refuge 


\title{
SOUND LEVEL ESTIMATION FOR ASSESSMENT OF UNDERWATER SHIP NOISE
}

\begin{abstract}
Among the several ways that human activities interfere in oceanic environment, acoustic noise is recognized as one of the most pervasive. Man-produced noise can have important consequences in marine fauna, since it impacts animal hearing as well as physiological and behavioral responses of oceanic organisms, inducing temporary or permanent injuries. Particularly, it can affect marine mammal communication, aquaculture and even fish industry productivity. Hazardous effects of anthropogenic noise on marine life have been intensively investigated over the last decades. Nevertheless, it was just recently that measurement of underwater anthropic noise close to harbors and industrial areas has become a true concern of environmental agencies in Brazil. On this subject, one case of great interest is the Port of Santos, the busiest container port in Latin America. This harbor is located on the Brazilian southeast coast, close to conservation areas with rich marine biodiversity, including marine mammals. For that reason, monitoring of underwater noise in the harbor area is especially important. In response to this need, an underwater noise monitoring program was established, providing quantitative information regarding harbor activities and marine traffic noise. Database presented in this work is characterized by Power Spectral Density (PSD), Sound Pressure Levels (SPL) and Sound Exposure Level (SEL) calculations. This work aims at complementing the nowadays limited information and can be regarded as a reference for future studies on underwater noise for Brazilian coastal areas.
\end{abstract}

Keywords: Ocean noise; sound exposure level; sound pressure level, underwater acoustic, passive acoustic monitoring 


\subsection{Introduction}

Underwater ocean noise has dramatically increased in the recent decades, studies estimating that ambient noise doubled each ten years since 1950s' (WARE, 2009). Navigation is probably the major contributor to this rise (THOMSEN, 2009), due to the increase in the number, size and propulsion power of ships around world oceans (THOMSEN, 2009; MCKENNA et al., 2012).Vessel noise concerns mainly low frequencies (below $300 \mathrm{~Hz}$ ), but Ship noise Frequency Bandwidth (SFB) extends to approximately 1 kHz (GÖTZ et al., 2009; MERCHANT et al., 2012). The SFB overlaps with frequencies that are used by several marine animals (see Figure 5), primarily large whales, seals, sea lions, and fishes (GÖTZ et al., 2009).

Coastal areas in which high-density shipping activities coexist with sensitive marine fauna are a true concern since ship noise can produce long reaching, chronic, damaging effects on ocean fauna. An interesting case study is the port of Santos, the largest in Latin America (TORRES et al., 2009). This harbor is situated on the southeast brazilian coast, close to marine conservation areas. The region has rich marine biodiversity that includes marine mammals (ROCHA-CAMPOS; MARINI-FILHO; ENGEL, 2007; GONÇALVES; ANDRIOLO, 2009; GONÇALVES; AUGUSTOWSKI; ANDRIOLO, 2016). The facts show that it is critically important to obtain metrics that could be used to characterize noise levels near Santos Harbor.

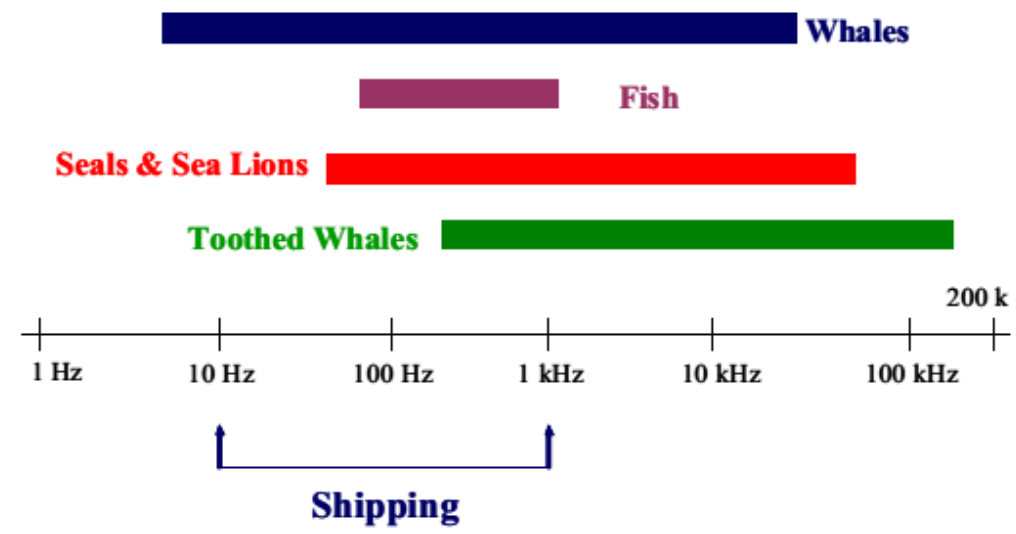

Figure 5 - Nominal ship noise frequency band displayed with frequency band of sounds emitted by several species. Font: (GÖTZ et al., 2009)).

Through the calculation of the quantities shown before from acoustic data collected near the port of Santos, this work aims:

1. To state a reference for underwater noise levels in the neighborhood of the port.

2. To estimate the power concentration within the Ship Frequency Band.

3. To compare underwater ambient noise recorded in two different seasons. 


\subsection{Materials and methods}

\subsubsection{Passive acoustic monitoring (system) and Deployment site}

In order to acquire the underwater acoustic data, was employed the OceanBase cabled system. The acquisition unit was installed on the Ilha das Palmas, in Santos Bay, the hydrophone being located at coordinates S 24 00.421'; W 046 19.521', close to the entrance channel of Santos Harbor (Figure 6).

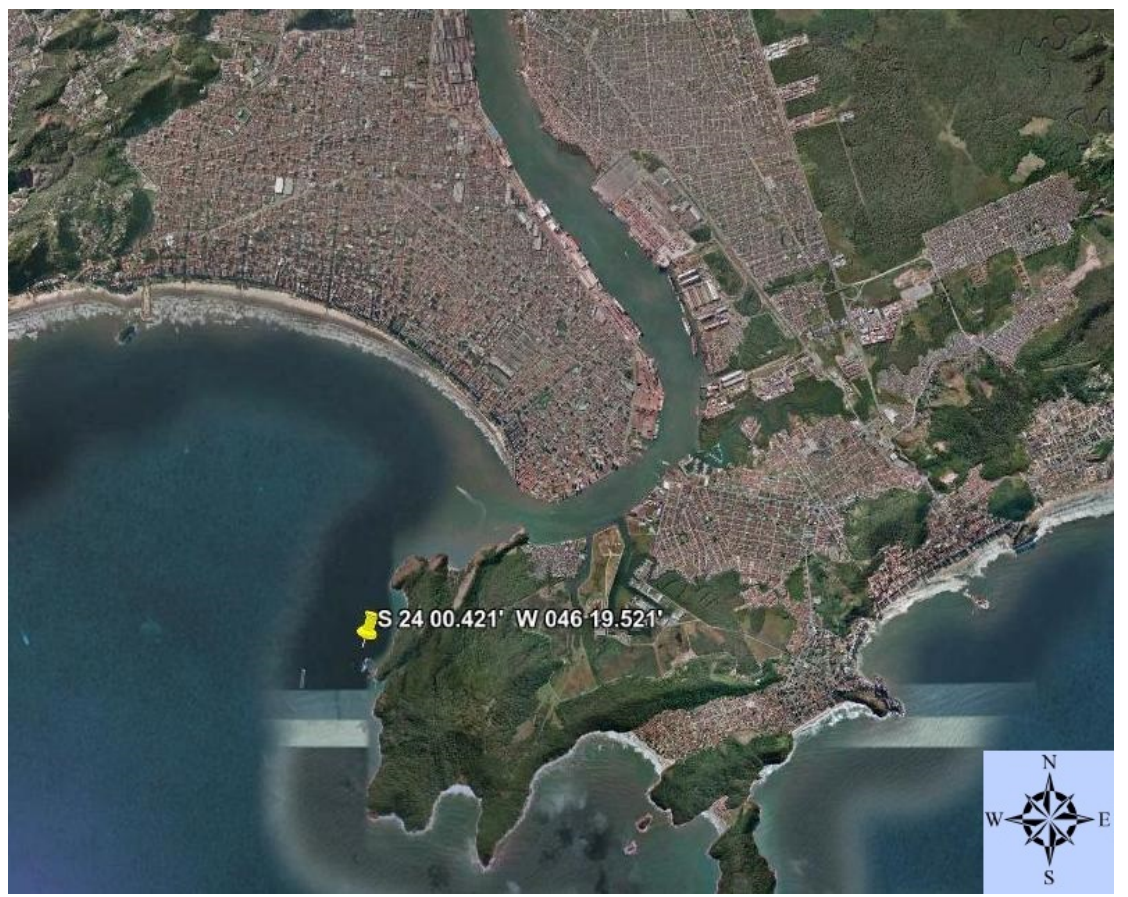

Figure 6 - Hidrophone locatated at Ilha das Palmas, Santos Bay, São Paulo State, Brazil.

The selected hydrophone location was chosen to fulfill two main conditions: be situated at a place where all vessels entering the channel could be recorded and, at the same time, at a position as close as possible to a point on land, with minimal conditions for installing and operating the acquisition unit.

\subsubsection{Data acquisition and processing}

Acoustic data was continuously recorded within two different periods; Period I: 28 days from October to November 2013, Period II: 17 days in April 2014. The OceanBase system acquired the acoustic signal with $16 \mathrm{kHz}$ sampling rate, 16 bit resolution, and saved it continuously in wav files of $15 \mathrm{~min}$ duration. The system sensitivity was set to $-150 \mathrm{~dB}$ re $1 \mathrm{~V} \mu \mathrm{Pa}^{-1}$.

The Power Spectral Density (PSD) was estimated by the Welch method with 1-s Hamming window and $50 \%$ of overlap, with 60-s signal segments for each wav file. In that way, Pxx matrixes were obtained. These matrixes were named here $\operatorname{Pxx}(n, m), n$ and $m$ indicating time and frequency indexes respectively.

1) SPL, SEL and $S E L_{w l}$ calculations 
Expressions 2.5 and 2.6 allow the determination of MSP and $M S P_{w l}$ in any frequency band of interest and combined with expressions 2.1 and 2.3, can be used to obtain SPL, SEL and $S E L_{w l}$ in such bands. Particularly, the calculations were realized in the SFB $(0.01-1 \mathrm{kHz})$ and, for the Full Frequency Band (FFB), recorded from $0.01-8 \mathrm{kHz}$.

2) Daily and total mean PSD

Daily Pxx matrices calculated for sampled days were averaged in time dimension, thus resulting daily mean PSD curves. These results were averaged again over sampled days so that a total mean PSD was determined. Daily and total mean PSD were used as an indicator on the frequency distribution of the acoustic data.

\subsection{Results and discussion}

The results presented below can be split in two parts. The first part addresses the estimation of ship contribution to total noise based on a sample of 11 days. The second one refers to an assessment of environmental noise recorded for two different periods in the port of Santos.

\subsubsection{Estimating ship contribution to total noise}

The data analyzed in this section is referent to a sample of 11 days, recorded between October 11 to 21, 2013. Table 1 illustrates mean, minimum and maximum values of SPL, SEL and m-weighted SEL calculated for recorded days. SPL values, from SFB in Table I, are similar to levels reported for other regions (MERCHANT et al., 2012) and occasionally even higher (HATCH et al., 2008; MCKENNA et al., 2012). It is important to note that SPL around $120 \mathrm{~dB}$ re $1 \mu \mathrm{Pa}^{2}$ can have negative influence for some whales and fish (CODARIN et al., 2009; SOUTHALL et al., 2007; VASCONCELOS; AMORIM; LADICH, 2007). Calculated weighted SEL agrees with other results (MERCHANT et al., 2012a; SOUTHALL et al., 2007), Low-Frequency cetaceans (hearing group I) have the highest sensitivity to SFB, followed by Pinnipeds (IV) and Mid-Frequency (II) and High-Frequency cetaceans (III), see Table 1.

Table 1 - Statistics from SPL, SEL, m-meighted SEL (SEL $L_{W_{I}}, S E L_{W_{I I}}, S E L_{W_{I I I}}$ and $\left.S E L_{W_{I V}}\right)$.

\begin{tabular}{ccccccc}
\cline { 2 - 7 } & \multicolumn{3}{c|}{$\mathrm{SFB}$} & \multicolumn{3}{c}{ FFB } \\
\hline Data & mean & min & max & mean & min & max \\
\hline SPL $\left(\mathrm{dB}\right.$ re $\left.1 \mu \mathrm{Pa} a^{2}\right)$ & 119.15 & 102.18 & 148.86 & 122.19 & 108.64 & 148.96 \\
$S E L\left(\mathrm{~dB}\right.$ re $\left.1 \mu \mathrm{Pa} a^{2} \mathrm{~s}\right)$ & 143.92 & 126.95 & 173.63 & 146.96 & 133.41 & 173.73 \\
$S E L_{W_{I}}\left(\mathrm{~dB}\right.$ re $\left.1 \mu \mathrm{Pa} a^{2} \mathrm{~s}\right)$ & 144.33 & 127.54 & 173.59 & 147.15 & 133.30 & 173.67 \\
$S E L_{W_{I I}}\left(\mathrm{~dB}\right.$ re $\left.1 \mu \mathrm{Pa} a^{2} \mathrm{~s}\right)$ & 141.45 & 126.00 & 170.26 & 145.37 & 133.10 & 170.50 \\
$S E L_{W_{I I I}}\left(\mathrm{~dB}\right.$ re $\left.1 \mu \mathrm{Pa} a^{2} \mathrm{~s}\right)$ & 140.31 & 125.15 & 168.92 & 144.73 & 132.92 & 169.32 \\
$S E L_{W_{I V}}\left(\mathrm{~dB}\right.$ re $\left.1 \mu \mathrm{Pa} a^{2} \mathrm{~s}\right)$ & 143.21 & 127.02 & 172.33 & 146.45 & 133.37 & 172.43 \\
\hline
\end{tabular}

Figure 7 shows that the power of recorded acoustic data is principally concentrated within the SFB, which suggests the prevalence of shipping noise over other acoustic components. The daily periodical acoustic event around $1 \mathrm{kHz}$ are related to fish choruses. The species that originated the choruses was not identified, since the study was not focused on particular event identification, but on more general goal of 
noise levels estimation and spectral characterization. However the topics of fish choruses will be analyzed in more details in following chapters.

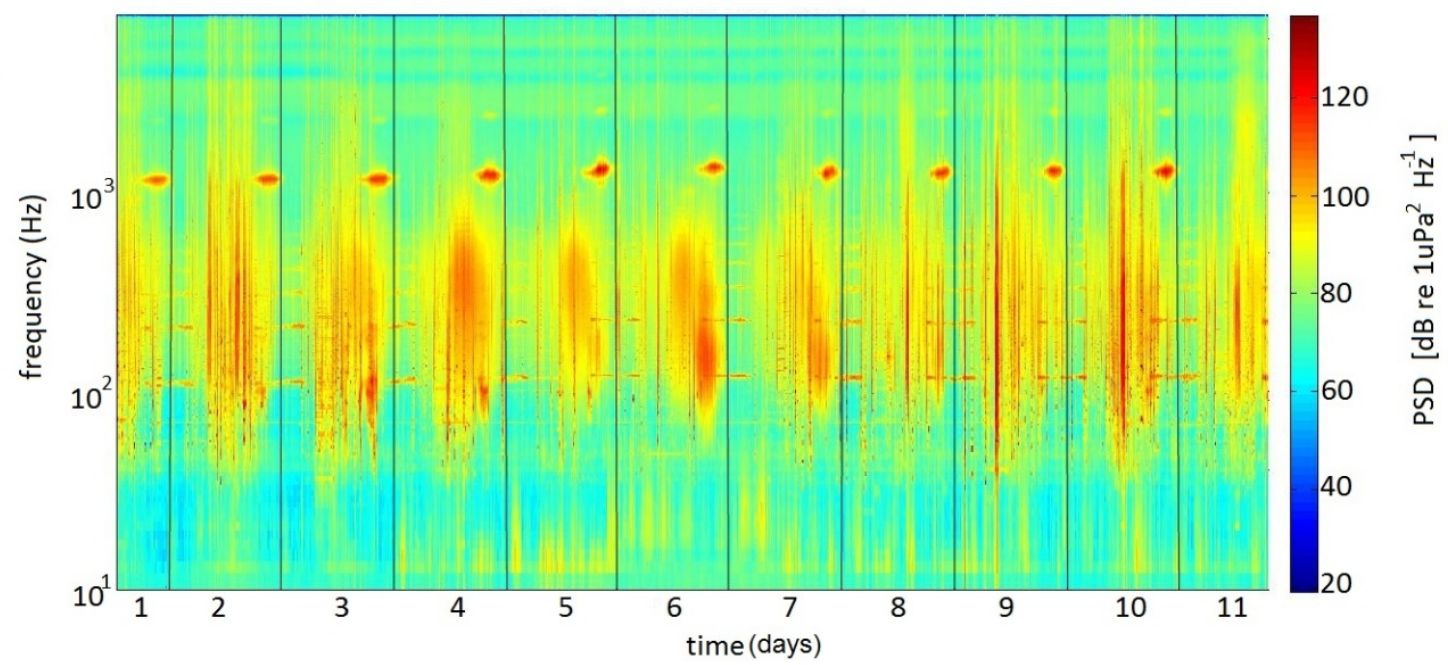

Figure 7 - Spectrogram of underwater sounds collected from October 11 to October 21, 2013, at Ilha das Palmas. Energy concentration below $1 \mathrm{kHz}$ is related to ship noise, nocturnal sound events appear slightly above $1 \mathrm{kHz}$ and are related to fish choruses.

Figure 8 (a) and Figure 8 (b) show the daily and total mean PSD. In these figures, two highlighted areas can be observed; a less intensely colored area (A1) and a more intensely colored area (A2). A1 represents the SFB and A2 represents the frequency band from $25-290 \mathrm{~Hz}$, here named Low Frequency Band (LFB). Inside A2, a rise in the PSD is evident, which agrees with statements of shipping noise concentration below $300 \mathrm{~Hz}$ (MERCHANT et al., 2012; GÖTZ et al., 2009).
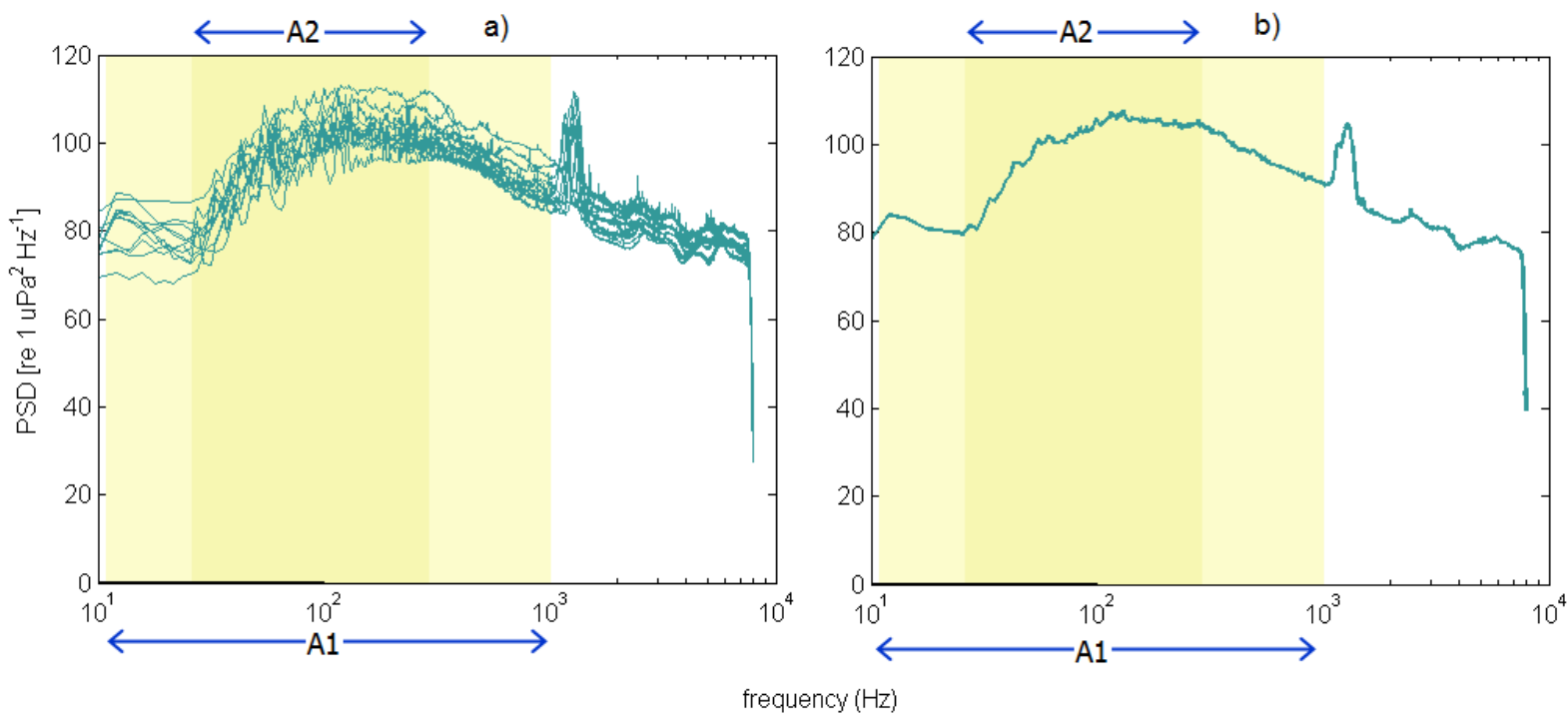

Figure 8 - Mean PSD calculated from of underwater sounds collected from October 11 to October 21, 2013, at Ilha das Palmas. a) Daily mean PSD and b) total mean PSD. 
to the power in FFB $\left(P_{F F B}\right)$ was estimated. Also the ratio of the power inside the LFB $\left(P_{L F B}\right)$ in relation to PFFB was determined. Although the SFB represents the $12.5 \%$ of the FFB, the $P_{S F B}$ proved to be $71.3 \%$ of $P_{F F B}$. In addition, $P_{L F B}$ was $46.9 \%$ of $P_{F F B}$, an unsuspected result based on the fact that LFB represents only $3.4 \%$ of FFB. In contrast, for frequencies outside the SFB, named here non-SFB (NSFB), its power contribution $\left(P_{N S F B}\right)$ was $28.7 \%$ of $P_{F F B}$.

In order to better understand $P_{N S F B}$, another estimation of the mean PSD was carried out (mean $P S D^{1}$ ). For this, the periods of time corresponding to the fish choruses observed in Figure 7 were excluded. From Figure 9 it is possible to see that the two estimations differ basically in a considerable peak reduction above $1 \mathrm{kHz}$. For the second estimation, emerged that, in respect to $P_{F F B}, P_{S F B}$ represents the $91.8 \%$, $P_{L F B}$ represents the $59.7 \%$ and $P_{N S F B}$ represents only $8.2 \%$. The above mentioned results are summarized in Table 2.

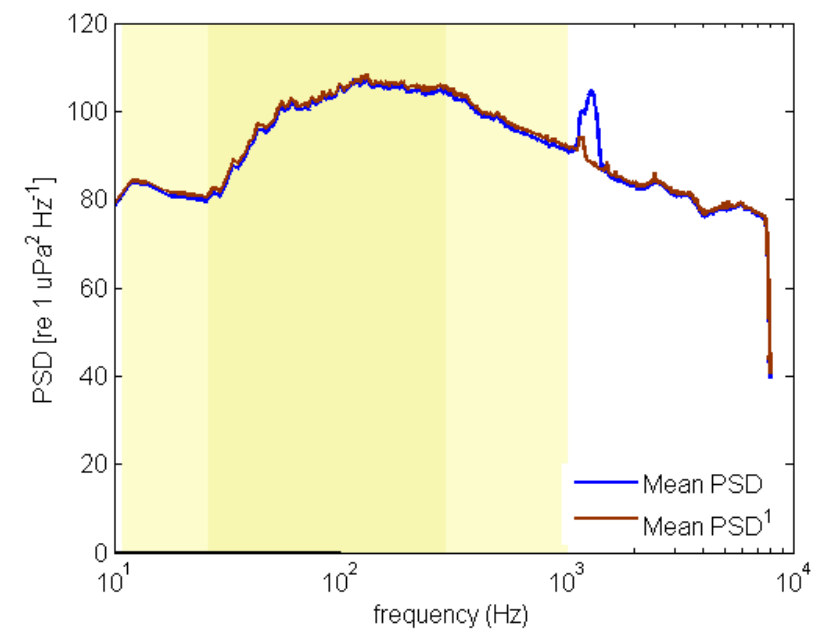

Figure 9 - Mean PSD calculated from of underwater sounds collected from October 11 to October 21, 2013, at Ilha das Palmas. Mean $P S D^{1}$ was calculated excluding fish chorus periods for each day.

Table 2 - Ratios between power concentrations within frequency bands of interest, SFB: $10 \mathrm{~Hz}-1 \mathrm{kHz}, \mathrm{LFB}: 25$ $290 \mathrm{~Hz}$, NSFB: $1-8 \mathrm{kHz}, \mathrm{FFB}: 10 \mathrm{~Hz}-8 \mathrm{kHz}$.

\begin{tabular}{llll}
\hline Ratios (\%) & SFB/FFB & LFB/FFB & NSFB/FFB \\
\hline Frequency ranges & 12.5 & 3.4 & 87.5 \\
Power & 71.3 & 46.9 & 28.7 \\
Power $^{1}$ & 91.8 & 59.7 & 8.2 \\
\hline
\end{tabular}

\subsubsection{Comparisons between two different periods}

Figure 10 represents the box plot for SPL in full frequency band obtained for periods I and II. In this figure are annotated the median, percentiles $25^{\text {th }}$ and $75^{\text {th }}$ and upper and lower limits $V_{1}$ and $V_{2}$; Figure 10 summarizes the SPL variability with time. In contrast, Figure 11 (a) and Figure 11 (b) show the PSD percentiles $1^{\text {st }}, 5^{\text {th }}, 50^{\text {th }}, 95^{\text {th }}$ and $99^{\text {th }}$ for the studied days, offering a frequency characterization of ambient noise. 
It is worth noting that Figure 10 and Figure 11 show ambient noise levels within two different seasons for an area close to the port of Santos, establishing a reference, which can be used as baseline for future studies.

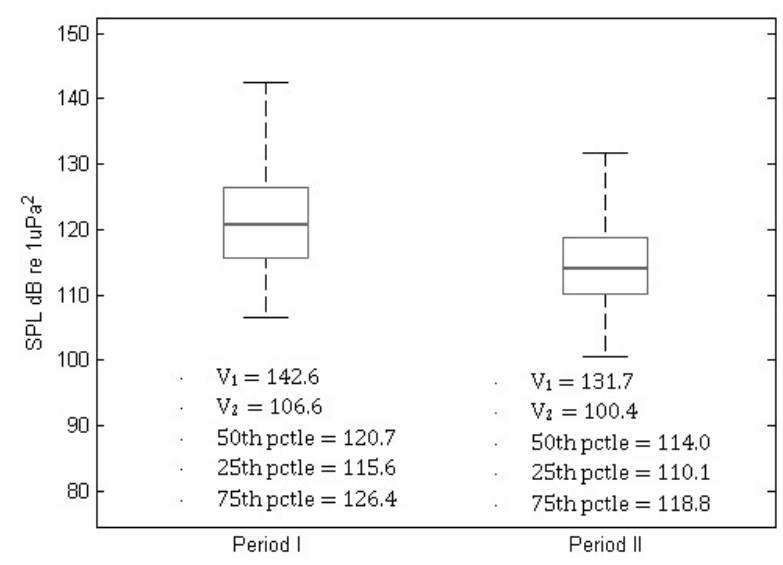

Figure 10 - Box plot representation of SPL in full frequency band for underwater sounds collected at Ilha das Palmas, from Periods I and II.

a)

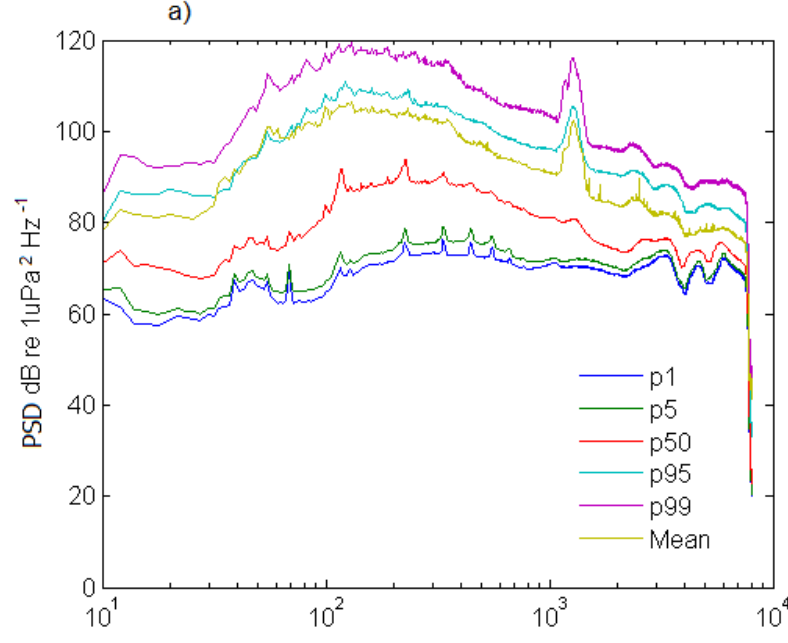

b)

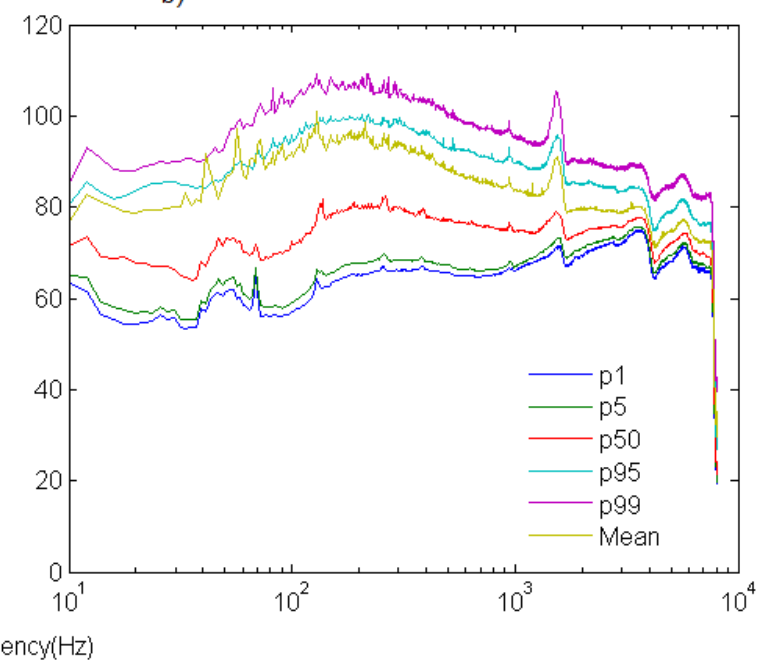

Figure 11 - Power Spectral density percentiles $1^{\text {st }}, 5^{\text {th }}, 50^{\text {th }}, 95^{\text {th }}$ and $99^{\text {th }}$ for underwater sounds collected at Ilha das Palmas, a) Period I and b) Period II.

It is possible to observe from Figure 10 and Figure 11, that acoustic levels for Period I are superior to levels for Period II. In order to better understanding this sound level difference, an analysis by $1 / 3$ frequency band was accomplished. SPL 1/3 octave bands of signals from Period I and II were computed. The median was selected as a criterion to determine the $1 / 3$ octave band in which differences between periods were the highest. The median is commonly employed and recommended to describe ambient noise data, since recognizably it is less influenced by high amplitude transient events (ROBINSON; LEPPER; HAZELWOOD, 2014). Table 3 shows the bands selected by the procedure explained before, the median and its difference for SPL in $1 / 3$ octave bands. 
Table 3 - Median and its difference for SPL in selected 1/3 octave bands for the two Periods.

\begin{tabular}{cllllll}
\hline Units & \multicolumn{6}{c}{$\mathbf{1 / 3}$ octave bands (Hz) } \\
dB re $\mathbf{1} \mu \mathrm{Pa}^{2}$ & $\mathbf{8 0}$ & $\mathbf{1 0 0}$ & $\mathbf{1 2 5}$ & $\mathbf{2 0 0}$ & $\mathbf{2 5 0}$ & $\mathbf{3 1 5}$ \\
\hline Period I median & 94.5 & 100.9 & 107.6 & 107.9 & 109.5 & 107.6 \\
Period II median & 84.8 & 87.9 & 97.0 & 97.1 & 99.6 & 98.0 \\
Differences & 9.7 & 13.0 & 10.6 & 10.7 & 9.8 & 9.6 \\
\hline
\end{tabular}

Figure 12 illustrates box plot for the selected 1/3 frequency bands that appear in Table 3.

a)

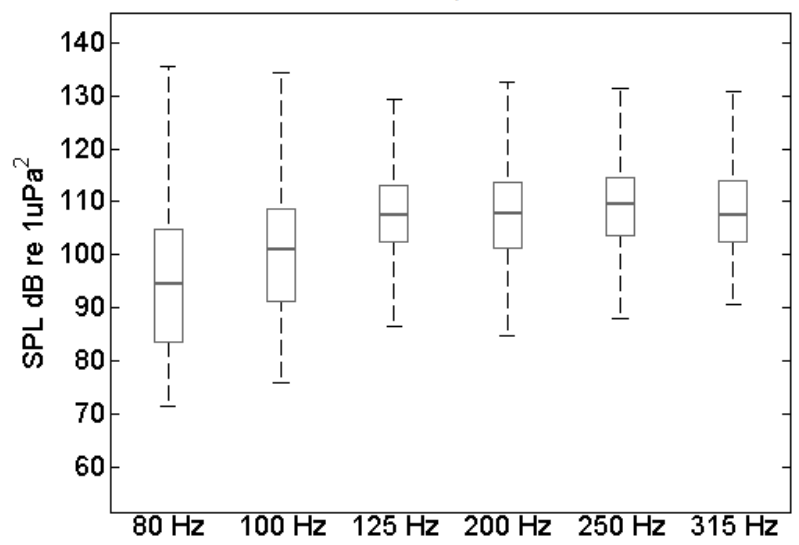

b)

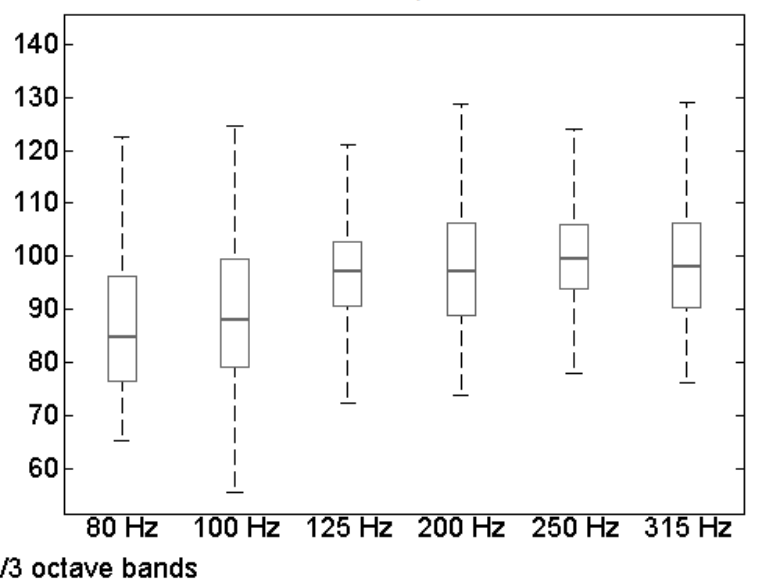

Figure 12 - Box plot from SPL in the selected 1/3 octave bands: $80 \mathrm{~Hz}, 100 \mathrm{~Hz}, 125 \mathrm{~Hz}, 200 \mathrm{~Hz}$ and $250 \mathrm{~Hz}$, a) from Period I and b) from Period II.

Results show that the principal differences, in ambient noise for Periods I and II, are in the 1/3 frequency bands centered at 80,100,125, 200, 250 and $315 \mathrm{~Hz}$. The average of the mean differences for those respective bands is $10.6 \mathrm{~dB}$.

Many studies have characterized the relative contributions of vessels to ambient noise in areas with different shipping densities. These studies have pointed out that ships are the predominant source for low frequency noise bands (MERCHANT et al., 2012; GÖTZ et al., 2009).

Underwater radiated noise from ships depend on the type, size, mode of propulsion, operational characteristics, speed, and other factors, being propeller cavitation the most notable (MCKENNA et al., 2012). Noise radiated from ships, generally decreases in frequency content with increasing ship size (GÖTZ et al., 2009), indicating that medium and large size vessels have a frequency contribution to ambient noise that is about some hundred $\mathrm{Hz}$ (GARRETT et al., 2016; HILDEBRAND, 2009). Thus, the results suggest that the noise levels decrease between periods I and II could be related to the decline in medium and large size ship traffic.

\subsection{Conclusions}

This work has estimated Sound Levels from underwater acoustic data measured near the Port of Santos, the biggest port in Latin America. The data was collected for two different seasons: 28 days from 
October to November 2013, 17 days from April 2014. The presented results demonstrated the existence of high concentration of power in bandwidth where vessels have their major contributions. These facts shows that for the monitored periods, the underwater ambient noise in the proximities of the Port of Santos, is mainly dominated by ship noise. The calculated sound levels reach values that can negatively impact some marine species.

In this sense, a reference was established which can be useful for ecologists and biologists to evaluate the influence of anthropogenic underwater noise on marine fauna. Indeed, the calculated values can be employed in order to compare the port of Santos with other regions and to assess ship noise evolution in time. 



\title{
UNDERWATER SOUNDSCAPE OF MARINE PROTECTED AREAS IN THE SOUTH BRAZILIAN COAST
}

\begin{abstract}
The Laje de Santos Marine State Park (LSMSP) and Xixová-Japuí State Park (XJSP) are two protected areas (PAs), close to the Santos Bay in the south Brazilian coast. The region encompasses both important biodiversity and anthropogenic activities. This study aims to serve as a first reference survey of the underwater soundscape of these PAs. Additionally it evaluates the presence of the anthropogenic and biological sounds in these areas. Approximately one month of continuous recorded underwater sound, at selected locations in XJSP and LSMSP, is used in this study. The data were characterized by its spectral content and by the temporal evolution of Sound Pressure Levels (SPL). Both locations showed sound events with daily periodicities, mainly related with boats and fish chorus.
\end{abstract}

Keywords: Ocean noise, Soundscape, Passive acoustic monitoring, Fish chorus

\subsection{Introduction}

Underwater soundscape of a given habitat is composed by biological, abiotic and anthropogenic sound sources. The acoustic environment, that may be accessed by a Passive Acoustic Monitoring (PAM) approach, plays a fundamental role for marine ecosystems (STAATERMAN et al., 2013). Additionally, long-term PAM can provide relevant information on temporal and seasonal patterns of marine habitats, and can also be employed to monitor acoustic pollution and its impacts (MERCHANT et al., 2015; ROUNTREE et al., 2006). Acoustic pollution can affect marine species, causing problems ranging from behavioral disturbances to loss of hearing, and even mortality (TASKER et al., 2010). Unfortunately, underwater noise has dramatically increased in recent decades. Studies estimate that ambient noise doubled in world oceans each ten years since 1950's (WARE, 2009). Ship traffic is recognized as the principal contributor to this acoustic noise rise, due to the increase in number, size and propulsion power of ships around world oceans (WARE, 2009; GÖTZ et al., 2009). In this context, coastal areas in which high-density anthropogenic sound sources coexist with sensitive marine fauna are a high priority. 


\subsubsection{Marine protected areas close to Santos Bay}

The vicinity of Santos Bay, in the southern Brazilian coast, is recognized as an area of great biodiversity (ARAUJO et al., 2013; JORGE; HARARI; FUJII, 2012) . At the same time, numerous sources of pollution can affect marine life in the bay region, particularly the activities related to its port. In consequence, the establishment of Laje de Santos Marine State Park (LSMSP), a marine protected area near the bay was crucial for ecosystem preservation.

Established in 1993, the LSMSP constitutes an important marine park of Sao Paulo state, Brazil (Amado Filho et al., 2006; JORGE; HARARI; FUJII, 2012). The park, located at coordinates $24^{\circ} 15^{\prime}$ $48^{\prime \prime}$, $46^{\circ} 12^{\prime} 00^{\prime \prime} \mathrm{W}$, holds valuable marine biodiversity with a variety of fishes, algae and also marine mammals (Amado Filho et al., 2006; LUIZ et al., 2008; ROCHA-CAMPOS; MARINI-FILHO; ENGEL, 2007). LSMSP serves as a key habitat for fish shoals, providing food, protection and the possibility of safe reproduction (GOBBATO, 2012).

\subsubsection{Xixová-Japuí State Park}

Xixová-Japuí State Park (XJSP), is located on the SW of Santos Estuarine System (São Paulo State, Brazil) at coordinates $24^{\circ} 0^{\prime} 22^{\prime \prime}$ S, $23^{\circ} 23^{\prime} 29^{\prime \prime} \mathrm{W}$. The XJSP encompasses a marine area inside the Santos bay and an adjacent inland region of tropical rain forest. Therefore, it is inside a region severely affected by environmental impacts, particularly unplanned urban settlement, industrialization and port activities (ARAUJO et al., 2013).

\subsubsection{Previous studies and objectives}

In spite of its importance, published material about environmental quality of Brazilian marine conservations units is really incipient. Particularly, there are no known studies about underwater soundscape of these sites. In addition, few studies on underwater ambient noise in Brazilian coastal areas are known, as examples: one (BITTENCOURT et al., 2014) in the Guanabara Bay, in Rio de Janeiro, and two others, regarding the Santos Harbor area (SANCHEZ-GENDRIZ; PADOVESE, 2014; SANCHEZ-GENDRIZ; PADOVESE, 2015). The cited studies aimed to reveal vessel noise contributions to total noise levels coming from the shipping activities.

The present paper provides the first description of the soundscape for the protected areas of LSMSP and XJSP. The work is based on approximately one month of continuous underwater acoustic records at these two different locations. Using Power Spectral Density (PSD), Spectrograms, percentiles and Sound Pressure Level (SPL) calculations, the data were analyzed and the spectral and temporal characterization of ambient noise were determined. Also, it is worth noting that this study brought valuable information for the management of the two mentioned conservation units. These results could be used to monitor the soniferous species that inhabit these areas, as well as to evaluate anthropogenic sounds and their impact on the ecosystem and also to detect and report illegal activities. 


\subsection{Methodology}

\subsubsection{Autonomous passive monitoring system and its deployment}

Underwater acoustic data was recorded by means of an autonomous passive monitoring system (OceanPod 1.0, see Figure 2). Acoustic data was recorded simultaneously in both sites (LSMSP and XJSP) from February 4 to March 1, 2015 ${ }^{1}$. The recording, carried out at $11.025 \mathrm{kHz}$ sampling rate (fs), 16 bit resolution, was continuously stored in a SD card, in wav files of $15 \mathrm{~min}$ durations. The sensitivity of the system was set to $-150 \mathrm{~dB}$ re $1 \mathrm{~V} \mu \mathrm{Pa}^{-1}$ and its frequency band set from $10 \mathrm{~Hz}$ to fs/2. Detailed explanation of this equipment can be found (CALDAS-MORGAN; ALVAREZ-ROSARIO; PADOVESE, 2015). Ninety six (96) wav files of 15 min duration were recorded each day in accordance with the described acquisition settings, totalizing 24 hours of recordings by day.

The selected measurement sites can be seen in Figure 13. The OceanPod located in XJSP was installed at $9 \mathrm{~m}$ depth and the other, in LSMSP, at $28 \mathrm{~m}$ depth, both at the bottom of the sea.

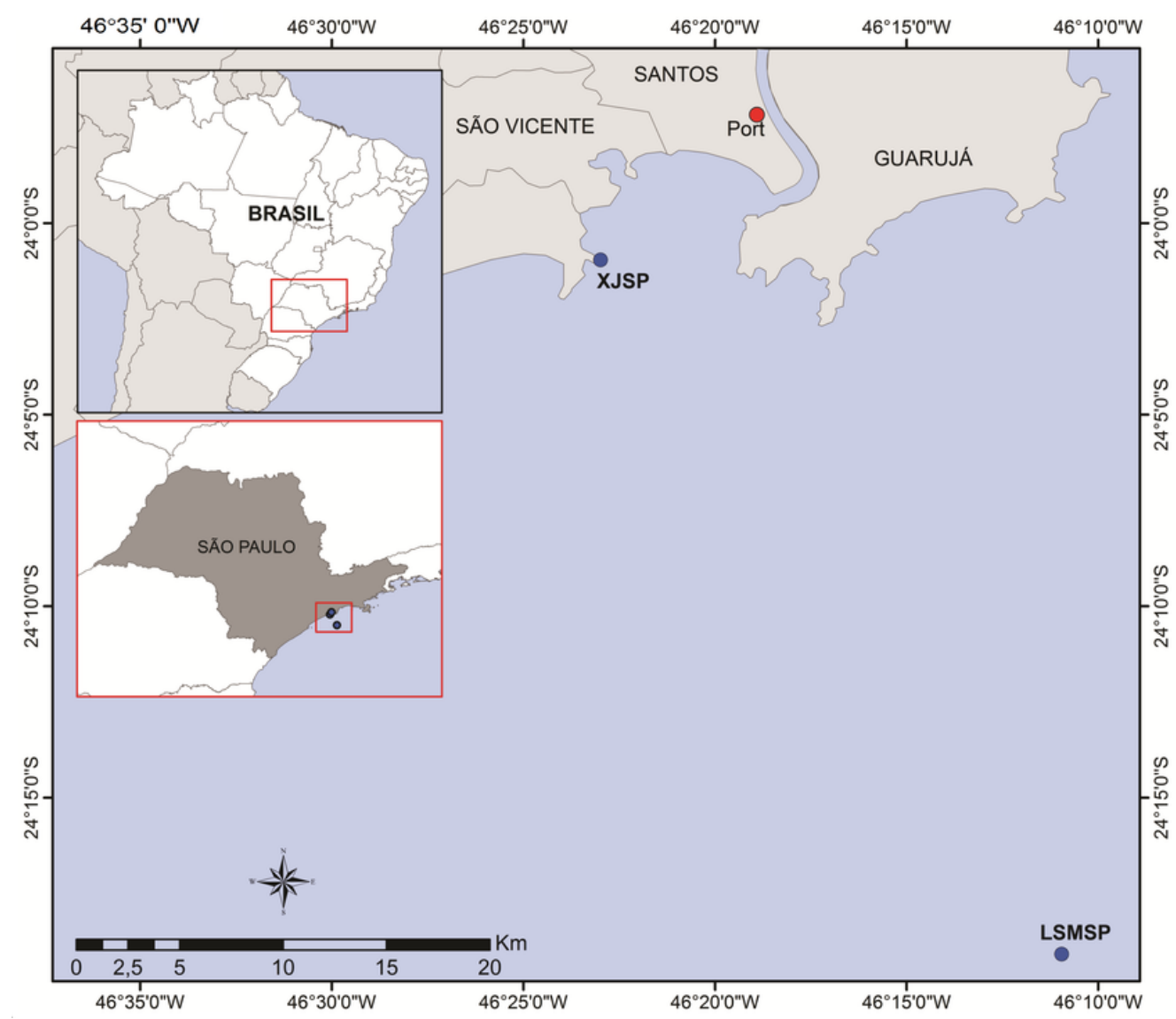

Figure 13 - XJSP (Santos Bay) and LSMSP localization.

1 A correction in recorded data was made. The monitored period descrived in (SANCHEZ-GENDRIZ; PADOVESE, 2016) apeared as February 2 to March 1, 2015. 


\subsubsection{Data processing}

The Power Spectral Density (PSD) (PROAKIS; MANOLAKIS, 2007) was estimated by the Welch method with 0.25 -s Hamming window, $50 \%$ of overlap, with 60 -s temporal signal segments. Therefore, with these parameters, time resolution is $60 \mathrm{~s}$ and frequency resolution is $5.6 \mathrm{~Hz}$. Parameters for calculating PSD were selected aiming to facilitate comparisons with others underwater monitoring studies (COQUEREAU et al., 2016; JORDÃO; FONSECA; AMORIM, 2012; MERCHANT et al., 2014; PARSONS et al., 2016a; PARSONS et al., 2016b) and to obtain an appropriated time-frequency spectrogram resolution for the present analysis. The resulted PSD matrices are named here as $\operatorname{Pxx}(n, m)$, been $\mathrm{n}$ and $\mathrm{m}$ time and frequency indexes respectively.

\subsubsection{Spectrogram representation}

A spectrogram can be obtained by a 2D plotting of Pxx matrices. This image representation affords a first insight of the major frequency band contributions for each analyzed location. By choosing convenient time and frequency intervals from $\operatorname{Pxx}(n, m)$, it is possible to plot a specific window of the time-frequency surface, i.e., a specific time period, or frequency band or both. Additionally, based on Pxx matrix, it is simple to calculate average spectrograms in order to highlight periodicities at different time scales. This approach has a special value in long-term underwater acoustic data analysis and interpretation.

\subsection{Results and discussion}

\subsubsection{Periodic events and spectral characterization}

Three sets of spectrograms, grouped two by two accordingly to each one of the two locations: a) LSMSP and b) XJSP, are presented in what follows. In the first set, Figure 14 shows the spectrograms of seven continuous monitoring days, here called a seven-day spectrogram. In the second set, Figure 15 presents spectrograms for one typical day, the daily spectrogram. Finally, in the third set, Figure 16, shows mean spectrograms. These mean spectrograms were calculated by the mean of the 26 daily spectrograms, which comprises spectrograms for the total time of monitoring and analysis in this chapter.

All these results show different information according to the way that the analysis is implemented. For each location, it is possible to tackle each daily 24-h spectrogram separately, a seven-day spectrogram, or else the daily-averaged spectrogram. Additionally, these types of spectrograms from both locations can be compared.

Firstly, for the seven-day spectrograms, a notable daily periodicity of acoustic events can be observed. This fact is more evident, or more intense, at XJSP, in which spectrograms show a richer periodic pattern. The daily periodic patterns can be observed thoroughly in Figure 15 and Figure 16. Based on their spectral and temporal dissimilarities, it can be stated that, in each location, periodic events seem to be originated by different sources.

One question that could be posed is which acoustic events, presented in the daily spectrogram, are periodic in long time scale. The analysis of the mean spectrogram can enlighten this subject. 
a)

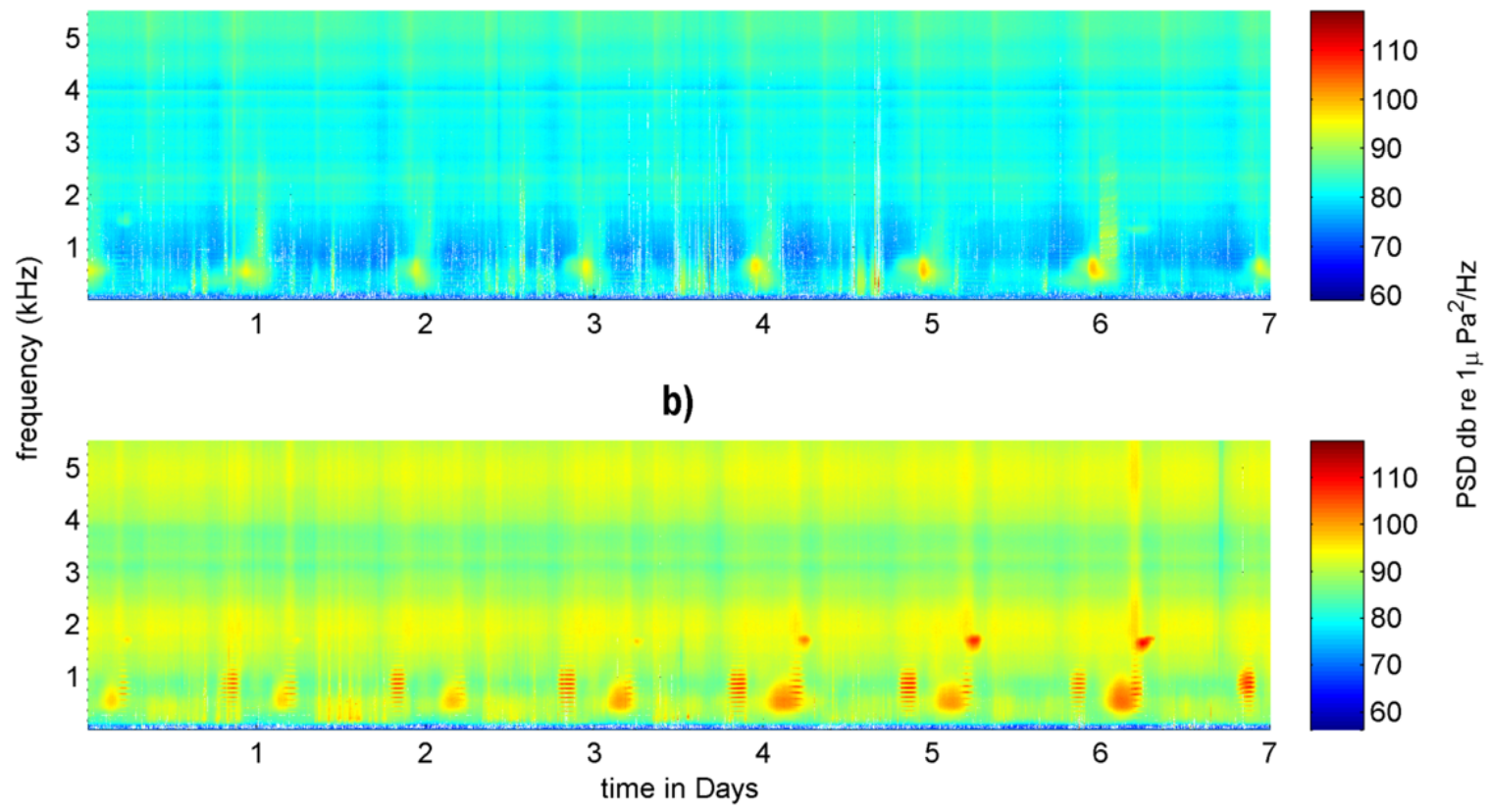

Figure 14 - Example of a Seven-day spectrogram from February 18 to February 24, 2015, (integration time $\mathrm{T}=60$ s), a) LSMSP and b) XJSP.

a)

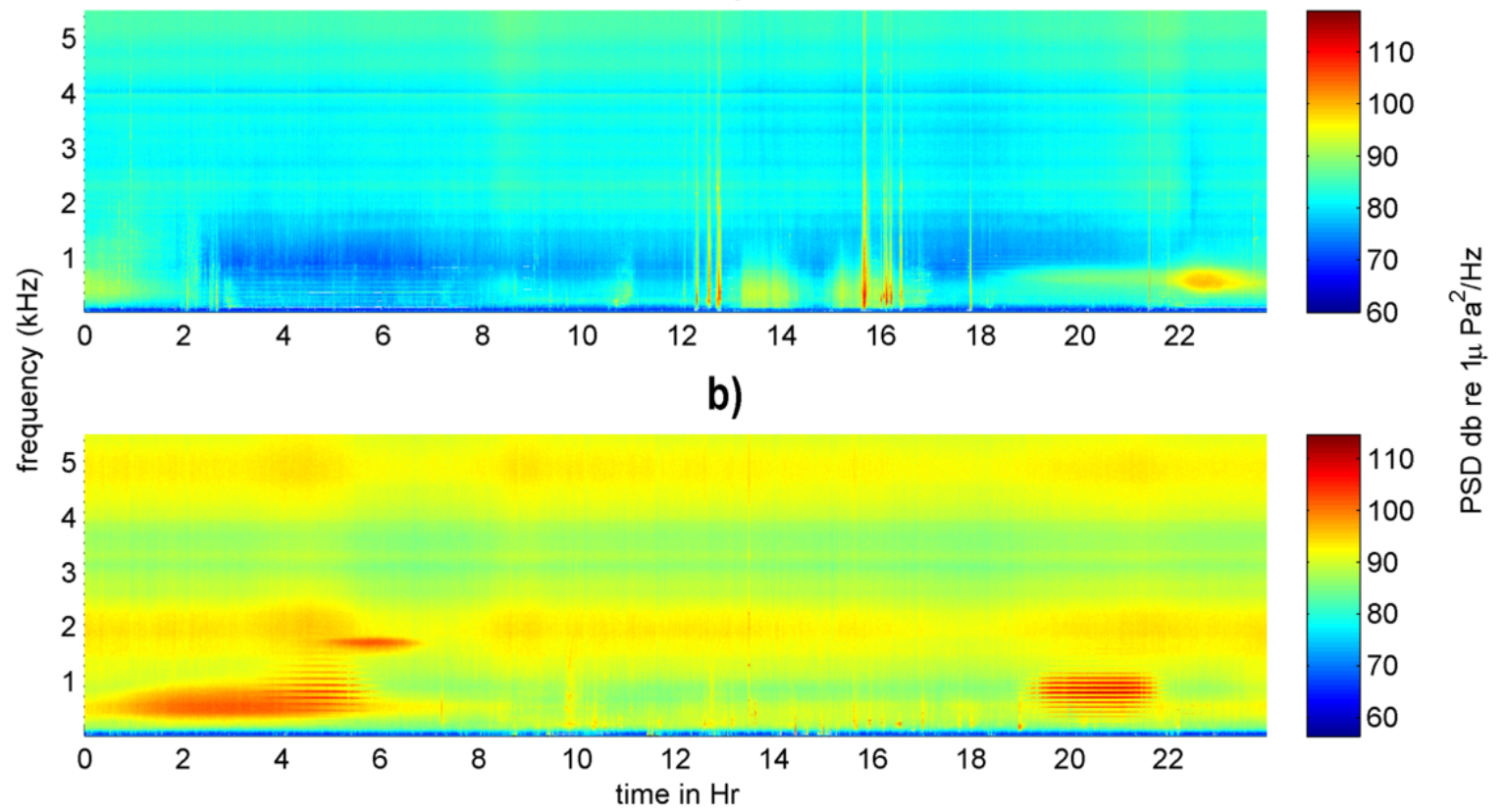

Figure 15 - 24-h spectrogram for February 22, 2015, (integration time T = $60 \mathrm{~s}$ ), a) LSMSP and b) XJSP.

A comparison of Figure 15 and Figure 16, shows the similarity between mean and daily spectrograms. Therefore, the daily soundscape is dominated by daily periodicities in both locations. In this sense, it is possible to state that mean spectrograms can point out the main acoustic events at each location. 
a)

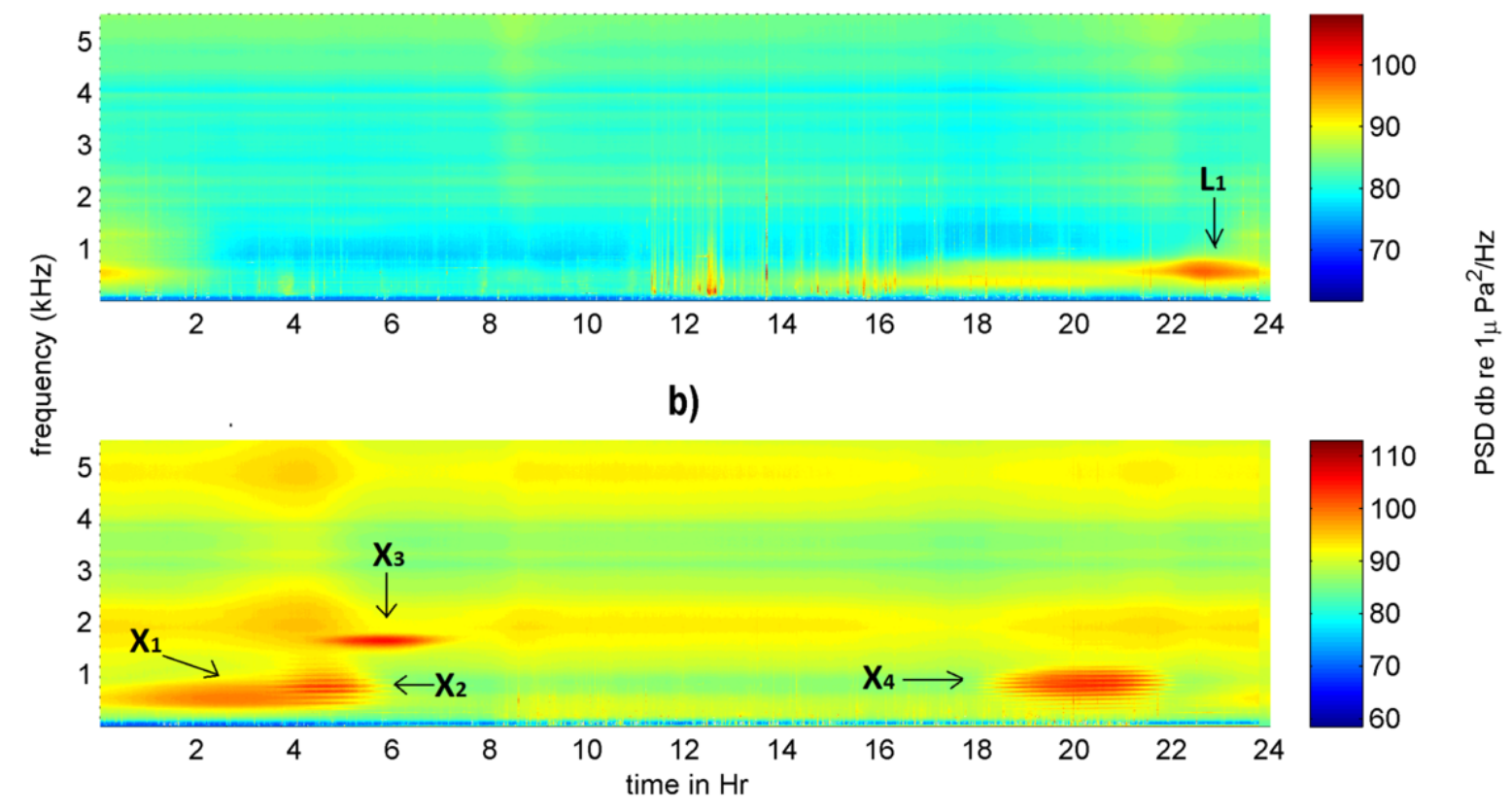

Figure 16 - 24-h Mean spectrogram, (integration time T = 60 s), a) LSMSP and b) XJSP.

Therefore, daily mean calculations will be used to describe the soundscape at each site. In order to assist with the description of temporal diel patterns showed in mean spectrograms, the daily mean Full Frequency Band (FFB) SPL of the 26 daily SPLs was also calculated. This quantity will be simply named as mean SPL.

Figure 17 shows the mean SPL for both locations. The highest values are related to the high level spots in the six spectrograms presented in this work.

From the LSMSP related figures, it is possible to observe acoustic events concentrated at between $11 \mathrm{~h}$ and $18 \mathrm{~h}$. These events are related to vessel passage, more probably to scuba-diving school ones, that use the LSMSP as a diving spot. However, the main acoustic event in LSMSP is the daily periodic event $\left(L_{1}\right)$ that occurs mostly between $21 \mathrm{~h}$ and $1 \mathrm{~h}$ and exhibits a diffuse spectral characterization (see Figure 16(a)). On the other hand, for the XJSP case (see Figure 16(b)), it is also possible to observe four main events highlighted by the average $\left(X_{1}, X_{2}, X_{3}\right.$ and $\left.X_{4}\right)$.

For the annotated events in Figure 16, the letter indicates the site (L for LSMSP and X for XJSP), and the suffix numerates the event for a specific location. The approximate patterns of these events are described in Table 4. Events $\left(L_{1}\right), X_{1}$ and $X_{3}$ exhibit diffuse spectral characterization, while events $X_{2}$ and $X_{4}$ are similar to spectral lines.

The origins of the events in Table 4 were not identified, but they are likely to be caused by fish chorus. A discussion that supports this statement is presented in what follows.

In both studied protected areas, fishing activity is forbidden, so it is reasonable to suppose that these sites are favorable places to find fish shoals. Sounds produced by fishes have been detected for centuries. Nowadays more than 800 fish species are known to produce sound (SLABBEKOORN et al., 


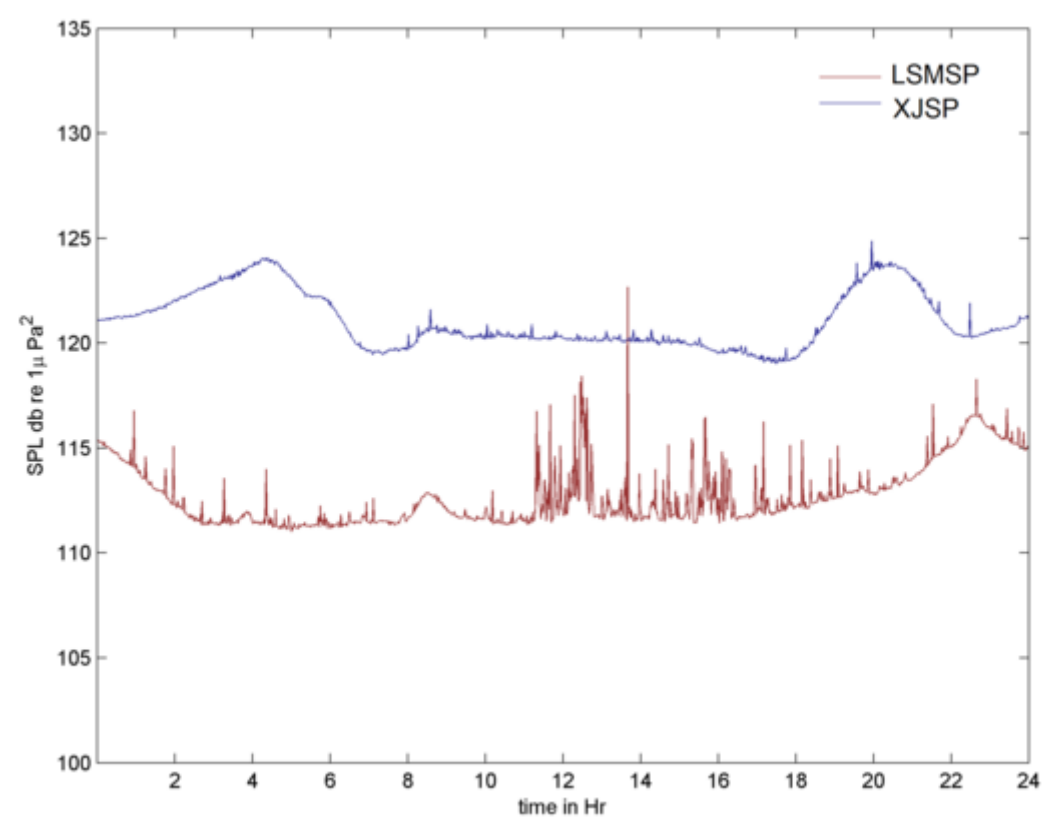

Figure 17 - Daily averaged FFB SPL.

2010), being included here some of the most abundant and commercial ones (PARSONS; MCCAULEY; MACKIE, 2013; ROUNTREE et al., 2006). Fish sounds are mostly produced in specific behavioral activities such as courtship and spawning, aggression, disturbance, and feeding (LUCZKOVICH et al., 2008; MANN; GROTHUES, 2009). In general, the most intense sounds are those associated with reproduction and often, as in other animals, only male produces sounds (ROUNTREE et al., 2006). Many fishes call for spawn mostly at dusk and night, which reduces the risk from visual predators on planktonic eggs and adults (LOCASCIO; MANN, 2008; LOCASCIO; MANN, 2005; MANN; GROTHUES, 2009). Also fish shoals produce sounds at dawn (MANN; GROTHUES, 2009).

Table 4 - Description of time frequency patterns of principal acoustics events in LSMSP and XJSP.

\begin{tabular}{lllll}
\hline Event & Start & End & $f_{\text {low }}$ & $f_{\text {high }}$ \\
\hline$L_{1}$ & $21: 00 \mathrm{~h}$ & $01: 00 \mathrm{~h}$ & $0.4 \mathrm{kHz}$ & $0.8 \mathrm{kHz}$ \\
$X_{1}$ & $00: 00 \mathrm{~h}$ & $05: 00 \mathrm{~h}$ & $0.4 \mathrm{kHz}$ & $0.8 \mathrm{kHz}$ \\
$X_{2}$ & $03: 00 \mathrm{~h}$ & $06: 00 \mathrm{~h}$ & $0.4 \mathrm{kHz}$ & $1.5 \mathrm{kHz}$ \\
$X_{3}$ & $04: 00 \mathrm{~h}$ & $07: 30 \mathrm{~h}$ & $1.5 \mathrm{kHz}$ & $1.8 \mathrm{kHz}$ \\
$X_{4}$ & $18: 00 \mathrm{~h}$ & $22: 00 \mathrm{~h}$ & $0.4 \mathrm{kHz}$ & $1.3 \mathrm{kHz}$ \\
\hline
\end{tabular}

There are no known references about bioacoustics characterization of fish chorus in Sao Paulo coast, which could help to analyze the events described in Table 4. However, Cusk-eel and Sciaenid fish families are important soniferous fish that can be founded in Southern Brazilian seas (CORDEIRO; LUQUE, 2004; SOARES; VAZZOLER, 2001). It can be observed that the events detected in LSMSP and XJSP (Figure 15 and Figure 16) have similarities with fish chorus from Cusk-eel and Sciaenid families of the USA coast, illustrated in Figure 18 and Figure 19. Especially, the events $L_{1}$ and $X_{1}$ are similar to chorus of Sciaenid. The calling of Cusk-eel family in Figure 18 is in the frequency band between 1 and $2.5 \mathrm{kHz}$, which include the frequency band of the event $X_{3}$. The spectrograms of supposed fish calling that could 
form the events $X_{2}$ and $X_{4}$ appear in Figure 20(a) and (b) respectively. Events $X_{2}$ and $X_{4}$ are characterized by constant spectral lines with several hours of duration. Biological choruses with these particularities have been reported also for Australian waters (MCCAULEY, 2012). Analyzing selected recorded sounds from XJSP, near the beginning and end of $X_{2}$ and $X_{4}$ events, allows finding some individual calls similar to those presented in Figure 20(a) and (b).

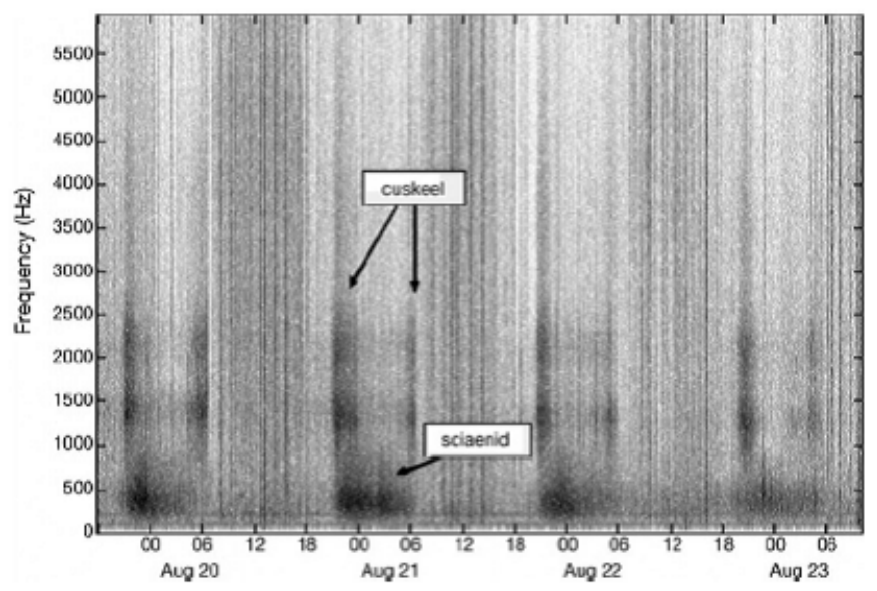

Figure 18 - Four day spectrogram from August 20 to 23, 2005 at the coast of southern New Jersey, USA (MANN; GROTHUES, 2009).

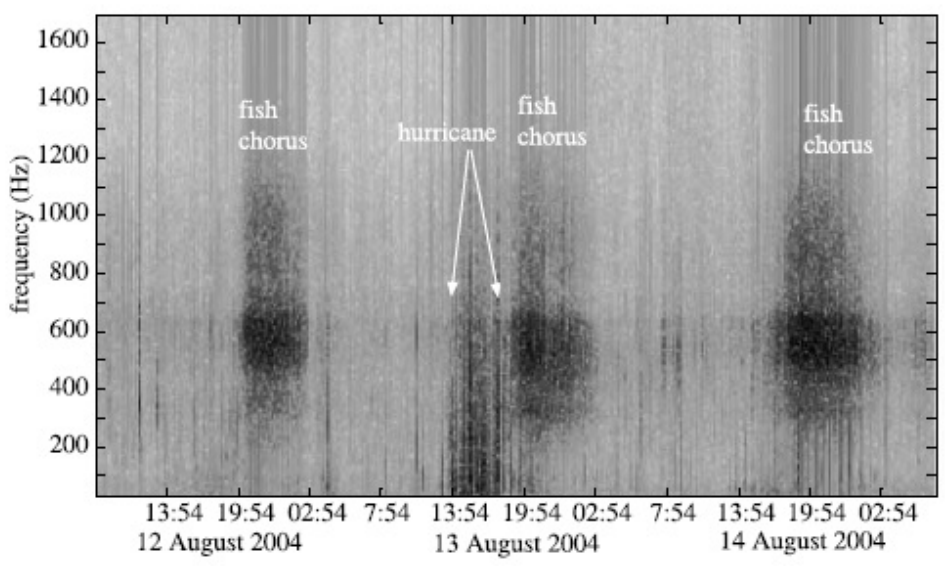

Figure 19 - Three days spectrogram that shows chorus from fishes of the Sciaenid family during the passage of a hurricane in Charlotte Harbor, Florida (LOCASCIO; MANN, 2005).

It is known that fish choruses present daily periodicities, such as those reported in this study. The chorus duration in (CATO, 1978; LOCASCIO; MANN, 2008) is similar to the one described in the present work. Studies have shown fishes maintain incredible long-term site fidelity. Indeed, some principal spawning sites have been used for more than 20 years (LOCASCIO; MANN, 2008) . In addition, some researchers have asserted that biological chorus often dominates acoustic environments at some habitats (ROUNTREE et al., 2006; LUCZKOVICH et al., 2008; PARSONS; MCCAULEY; MACKIE, 2013; RADFORD et al., 2008).

The present work does not aim to identify which fish species are responsible for those sounds that compose the soundscape of the studied sites, since the information collected for the present study is 
not enough for this purpose. However, the findings reveal one principal fact: the soundscapes of the both sites are dominated by biological events, likely fish chorus.

a)

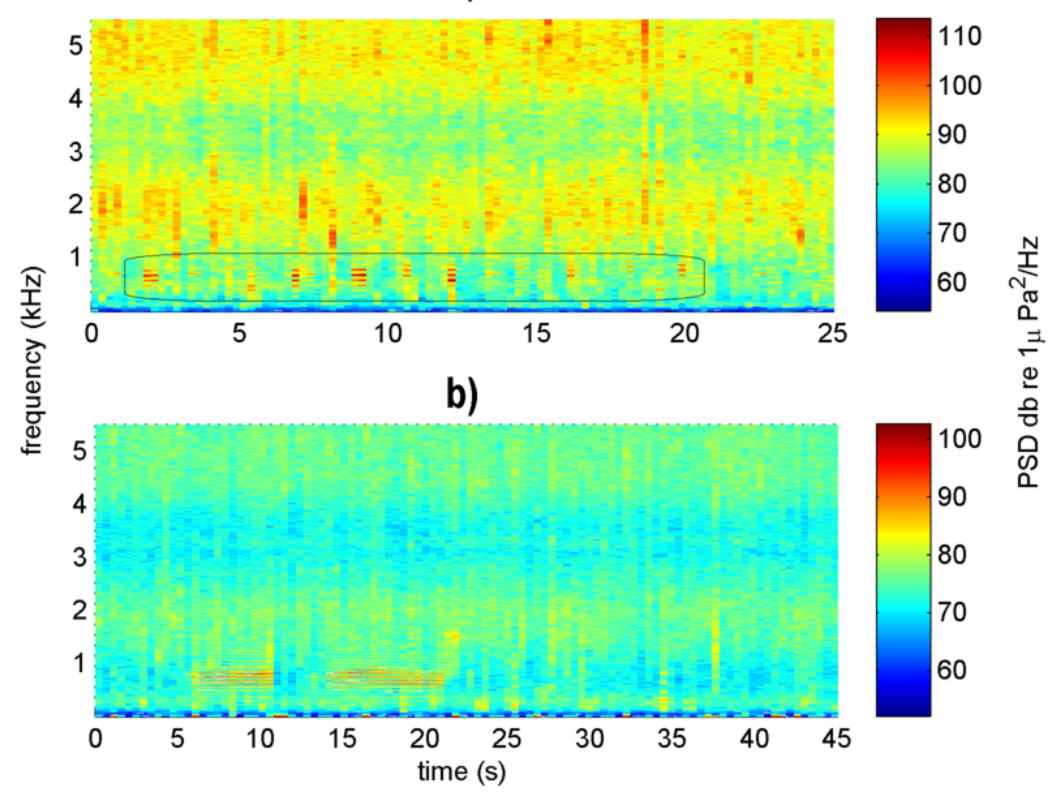

Figure 20 - Spectrogram of unidentified fish calls (integration time $\mathrm{T}=0.30 \mathrm{~s}$ ), a) sound in the vicinity of event $X_{2}$, b) sound in the vicinity of event $X_{4}$.

In fact, the result indicating that principal components of the acoustic environment of the studied habitats are fish choruses is a valuable finding. Often, expensive surveys are carried out in researches on fishes (ROUNTREE et al., 2006). In contrast, it is well known that numerous species of fishes are highly soniferous, so using the simplest PAM could serve as a primary approach to the study of fishes (LOCASCIO; BURTON, 2016; PARSONS; MCCAULEY; MACKIE, 2013; PARSONS et al., 2016b). As a first reference to this subject in the region, this work provides important information on temporal, spatial and spectral patterns of fish sound activities. Based on these results, new researches can be undertaken in order to study specific soniferous species. Possible applications include tracking of fish movements and species' behavioral and spawning habitats (LOCASCIO; BURTON, 2016; PARSONS; MCCAULEY; MACKIE, 2013). Since the present study was accomplished in two marine reserves, the resulting data could be used for management of the sites. In addition, these results could be used not only to monitor soniferous species that inhabit the area, but also to detect and report illegal activities.

One significant remark is that the simple calculation of mean average, for the analyzed data, allows underlining periodicities in an effective way. This procedure could be used as a plain exploratory approach to tackle long-term underwater acoustic data. By choosing different average time periods, it is possible to put in relevance periodical events with different periods; however, some cares should be taken. For example, it is possible that biological choruses present temporal drift throughout the year. This could result in spread of the average spectrograms in the time axis direction, and give the false impression that the choruses are longer than they are in any individual day. Therefore, the application of mean average is recommended for periods that do not present significant temporal drift, as for data presented in this study. 


\subsubsection{PSD percentiles and frequency characterization}

Another representation that helps to describe frequency content of the ambient noise was the PSD percentiles (see Figure 21). For LSMSP, the principal frequency content is concentrated within 90-900 $\mathrm{Hz}$ frequency band, showed as colored Region I in Figure 21(a). This power concentration is explained by the periodic event that was detected in Figure 16(a).

On the other hand, for XJSP, the main power concentration is mainly in the frequency bands: $90-1200 \mathrm{~Hz}$ (Region I), and $1500-1800 \mathrm{~Hz}$ (Region II), as the two colored regions in Figure 21 (b) illustrate. Additionally, for the frequency band signaled by Region I, frequency peaks appear in the mean and $95^{\text {th }}$ and $99^{\text {th }}$ PSD percentiles, and are related to the peaks that can be identified in Figure 16 (b), too. In addition, the power concentration in frequency band signaled by Region II can also be related with one of the events that appear in Figure 16 (b).

Figure 21 also illustrates that broadband noise level are supirior in XJSP. This fact can be explained by a higher crustacean activity in XJSP, crustacean noise is recognized to have a broadband energy distribuition (AU; BANKS, 1998; STAATERMAN et al., 2013).

As one can observe, the 24-h mean spectrogram not only represents periodical events, but it also summarizes the understanding of the frequency content.
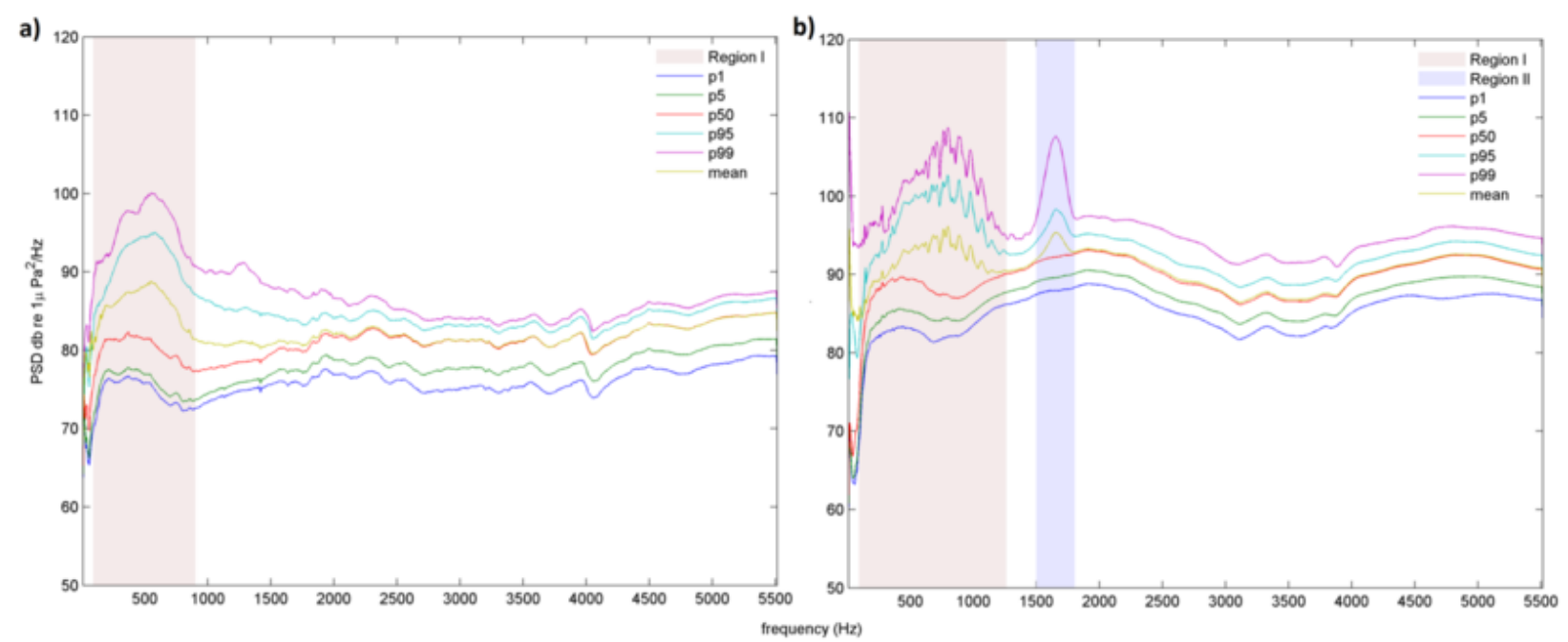

Figure 21 - Power Spectral density $1^{\text {st }}, 5^{\text {th }}, 50^{\text {th }}, 95^{\text {th }}, 99^{\text {th }}$ and mean percentiles, a) LSMSP and b) XJSP.

\subsubsection{SPL values and anthropogenic activities}

The statistical values, related to SPL, appear in Table 5 and are graphically represented in Figure 22. Results show that, in average, SPL values from LSMSP are inferior to those from XJSP in approximately $9 \mathrm{~dB}$. The range of SPL values not considered outliers is for LSMSP: $107.0-117.0 \mathrm{~dB}$ re 1 $\mu P a^{2}$ and for XJSP: $116.4-124.7 \mathrm{~dB}$ re $\mu P a^{2}$.

Figure 23 represents the traffic density of ships close to measurement locations (http://www.marinetraffic.com/). As expected, this figure indicates that the major concentration of ships occurs in the vicinity of Santos 
Harbor. This fact, in conjunction with the noise generated by industrial activities near Santos bay, implies that SPL in LSMSP is lower than in XJSP. Figure 22 and Table 5 confirm this fact and Figure 23 help to explain the higher SPL values at XJSP.

Table 5 - Representative values of SPL variability.

\begin{tabular}{lllllll}
\hline Site & \multicolumn{5}{c}{ Values $\left(\mathrm{dB}\right.$ re $\left.1 \mu \mathrm{Pa}^{2}\right)$} \\
\cline { 2 - 7 } & $L_{1}$ & $L_{2}$ & $q_{1}$ & $q_{3}$ & Median & Mean \\
\hline LSMSP & 107.7 & 117.0 & 11.0 & 113.2 & 111.9 & 111.9 \\
XJSP & 116.4 & 124.7 & 119.8 & 121.8 & 120.6 & 121.0 \\
\hline
\end{tabular}

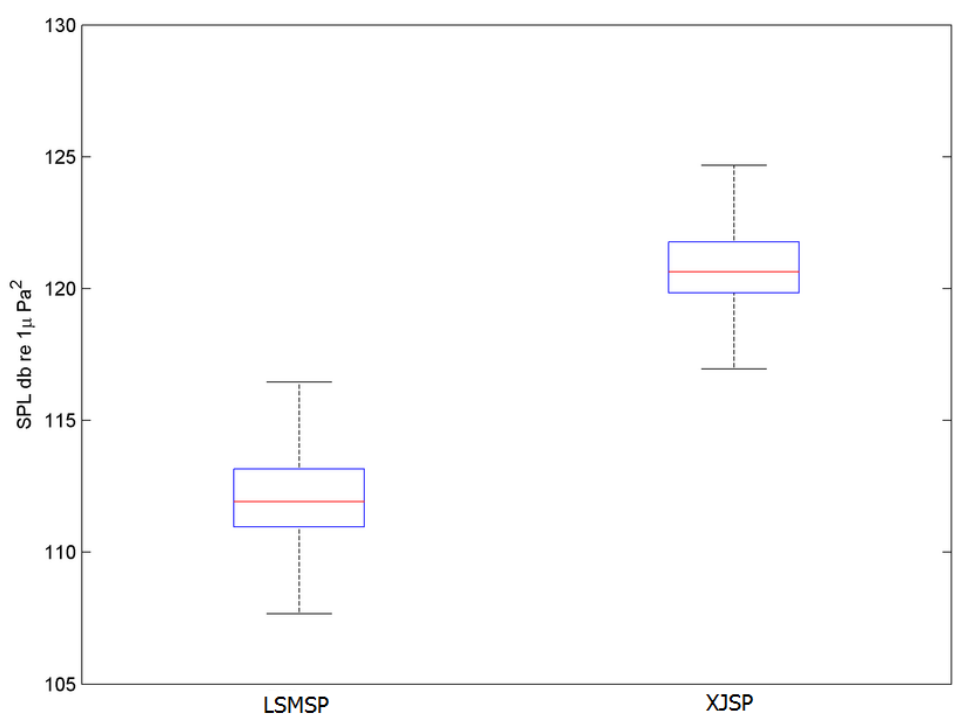

Figure 22 - Boxplot of FFB SPL of underwater sounds recorded from February 2 to March 1, 2015 for LSMSP and XJSP.

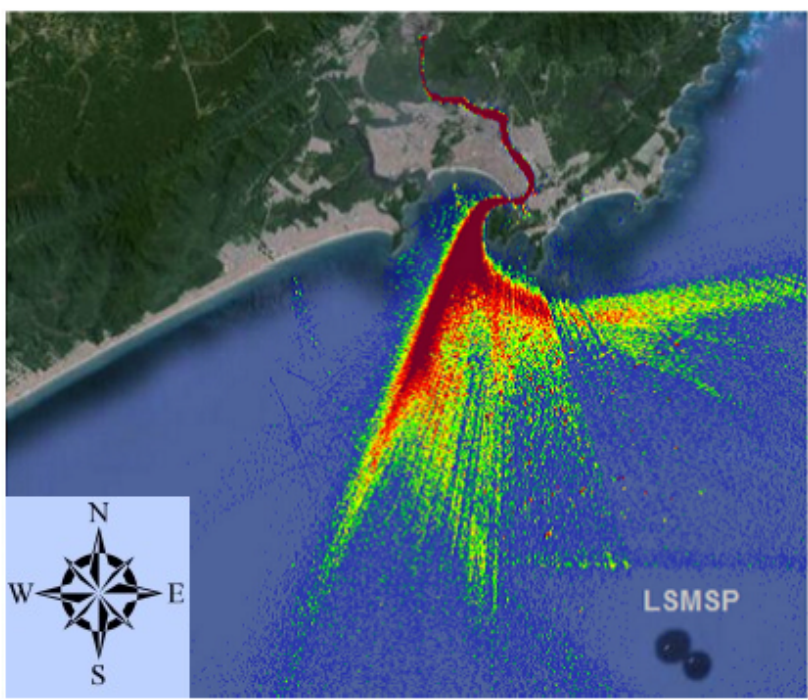

Figure 23 - Ship traffic density related to Santos port, São Paulo, Brazil. 
This maritime traffic implies in secondary shipping activities related to anchoring areas of huge vessels, where ships wait for accessing the docking area. This anchoring area is between Santos Bay and the LSMSP. The concentration of anchored ships also generates acoustic noise, but for the monitored period, this noise did not seem to affect the LSMSP soundscape significantly. The principal acoustic events that characterized the soundscape of the studied sites were events produced locally, which were originated by fish choruses.

\subsection{Conclusions}

In spite of its computational simplicity, calculation of the daily mean spectrogram proved to be an interesting tool in order to characterize periodic events in long-term passive acoustic monitoring data sets. By selecting different time scales of average, it is possible to highlight different periodic acoustic events in a data set.

This paper presents the first underwater soundscape characterization of important marine conservation units, near the biggest Brazilian commercial port. It also presents the acoustic characterization of underwater noise levels in Santos Bay. The acoustic environment in the Conservation Units is dominated by biological sounds, which show daily periodicities. These sounds are supposed to be originated by unidentified fish chorus. Further studies need to be undertaken to reveal the species that produce the sounds.

The results allow concluding that anthropogenic acoustic noise generated by Santos harbor activities do not apear as the dominant soundscape component at the LSMSP and XJSP. Instead biophony with diel cicles araises as the principal factor in both protected areas, at least during the studied period. 


\title{
TEMPORAL AND SPECTRAL PATTERNS OF FISH CHORUSES IN TWO PROTECTED AREAS IN SOUTHERN ATLANTIC
}

\begin{abstract}
The Laje de Santos Marine State Park (LSMSP) and Xixová-Japuí State Park (XJSP) are two protected areas (PAs) located in the southern Atlantic brazilian coast. One month of continuous underwater sound recordings allowed determining that durable fish choruses was a major contributor of LSMSP and XJSP soundscapes. The choruses showed well defined daily periodicities and exceeded background ambient noise for some hours every day, principally at dawn and dusk. This work describes the daily temporal patterns and spectral characteristics of the studied PAs choruses. Annotations of some chorus temporal descriptors (start, peak and end time instants) allow obtaining a precise statistical representation of diel chorus occurrence. Average Power Spectral Density and cepstral analysis were used to determine quantitative values for choruses spectral characterization. Results show that the passive acoustic technique could be a cost-effective method for management and fish monitoring in PAs.
\end{abstract}

Keywords: Underwater soundscape, passive acoustic monitoring, fish chorus, marine protected areas

\subsection{Introduction}

The region in the vicinity of Santos Bay, in southern Atlantic, is recognized as an area where a rich biodiversity coexists with numerous sources of pollution that can affect marine life (ARAUJO et al., 2013; JORGE; HARARI; FUJII, 2012). In view of that, the establishment and management of marine protected areas (PAs) in the region is a true concern for ecosystem preservation. The Laje de Santos Marine State Park (LSMSP), is a marine protected area located in southern brazilian coast. The park holds valuable marine biodiversity (Amado Filho et al., 2006; JORGE; HARARI; FUJII, 2012; LUIZ et al., 2008) with a high variety of marine life (fishes, turtles, mantas rays, among others). Additionally, marine mammal sightings (ROCHA-CAMPOS; MARINI-FILHO; ENGEL, 2007) in the site are reported, furthermore evidence indicates that LSMSP is used as feeding area by bryde whales (GONÇALVES; ANDRIOLO, 2009; GONÇALVES; AUGUSTOWSKI; ANDRIOLO, 2016). The park serves as an area 
for reposition of fish shoals, providing food, protection and the possibility of safe reproduction (Amado Filho et al., 2006). Close to the LSMSP, there exists another ecologically important area, the Xixová-Japuí State Park (XJSP), located in the southwest of Santos Estuarine System (São Paulo State, Brazil). The XJSP encompasses a marine area inside the Santos bay and an adjacent island region of tropical rain forest. Being located in the vicinity of Santos Harbour the biggest port in Brazil, all the conservation unit is inside a region severely affected by environmental impacts, particularly unplanned urban settlement, industrialization and port activities (ARAUJO et al., 2013).

For the dynamics and evolution of oceanic ecosystems, the acoustic environment can play an important role (BUSCAINO et al., 2016; MERCHANT et al., 2015). Patterns of the sounds that emanates from a particular place can be strongly linked to its specific characteristics and local fauna (PIJANOWSKI et al., 2011b). Especially, marine organisms have an important relation with its acoustical surroundings, since they depend on sound for communications, mating, hunting, avoiding predators and hazards and for navigation (MCWILLIAM; HAWKINS, 2013).

The collection of sounds that emanates from an environment is known as soundscape (PIJANOWSKI et al., 2011b), in scientific literature. Marine soundscape is based on the sounds related to geophony (physical events, such as wind, precipitation, breaking waves, earthquakes), biophony (mammals, fish, crustaceans), and anthropophony (man-made events) (ERBE et al., 2015).

A previous study (SANCHEZ-GENDRIZ; PADOVESE, 2016) described LSMSP and XJSP soundscapes for the first time. It was based on one month of continuous underwater sound recordings. The soundscape at both sites were dominated by durable acoustic events, likely related to unidentified fish shoal choruses. The choruses presented well defined daily periodicities, mainly at dusk and dawn. Five chorus types $\left(L S_{1}, X J_{1}, X J_{2}, X J_{3}\right.$ and $\left.X J_{4}\right)$ were highlighted by 24-h mean spectrogram (calculated by the arithmetic mean of daily 24-h spectrograms), as Figure 24 illustrates. The averaged values of start and end time instants of the choruses were estimated based on visual inspection of 24-h mean spectrogram and 24-h mean Sound Pressure Level (SPL).

The survey (SANCHEZ-GENDRIZ; PADOVESE, 2016) provides an interesting, but general point of view of LSMSP and XJSP soundscapes. The present paper adds a deeper insight to the biotic component, by particularly focusing in the characterizations daily chorus types. Specifically, the current work aims to analyse daily values of temporal and spectral descriptors for each chorus type presented in data:

- Temporal descriptors: start, end and peak time instants, where peak time instant refer to moment at which a specific chorus reach its maximum SPL value.

- Spectral descriptors: dominant frequency, bandwidth and, for chorus types $X J_{2}$ and $X J_{4}$ the interval of constant frequency between spectral peaks was also computed.

The daily values of computed descriptors allow to obtain a statistical overview of temporal and spectral features of each chorus type. 
a)

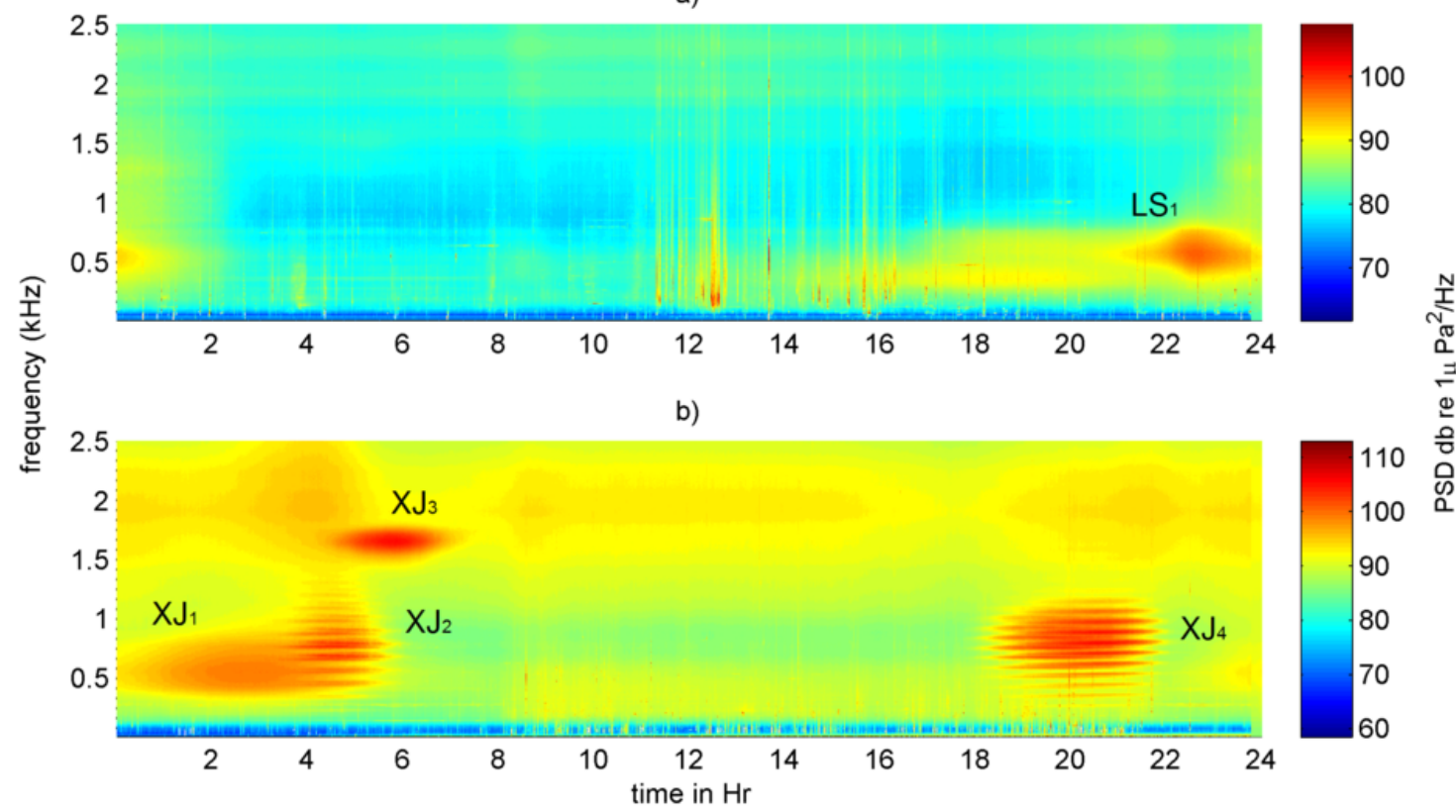

Figure 24 - 24-h mean spectrogram highlighting predominant acoustic events at studied PAs a) LSMSP and b) XJSP.

\subsection{Materials and methods}

The autonomus PAM system (OceanPod) and its configuration used for the data acquisition, as well as the monitored sites and data processing were described in chapter 4, section 4.2.

\subsubsection{SPL smoothing}

For the 24-h SPL curves, a symmetrical moving average filter (SMITH, 1999) was applied for minimizing transients events, which could be related to boat traffic, while preserving the overall trends associated with fish choruses (LOCASCIO; MANN, 2008). A 61 points rectangular window was selected for the filter kernel. Since time resolution of SPL series is 60 seconds, the number of samples used to implement the filter represents a signal duration of $60 \mathrm{~min}$, close to values used in other studies about fish choruses (LOCASCIO; MANN, 2005; LOCASCIO; MANN, 2008; LOCASCIO; BURTON, 2016).

Figure 25 exemplifies the application of that kind of filter for the SPL curve of February 7, 2015 in XJSP. This figure confirms that the response of the filter removes the transients in the signal and, at the same time, preserves the slow variations that could be related to fish chorus. Based on this fact, the smoothed SPL was used in this studied to characterize the sound levels related to fish chorus.

For the rest of this chapter, the smoothed SPL will be identified by SPL simply, unless otherwise noted. 


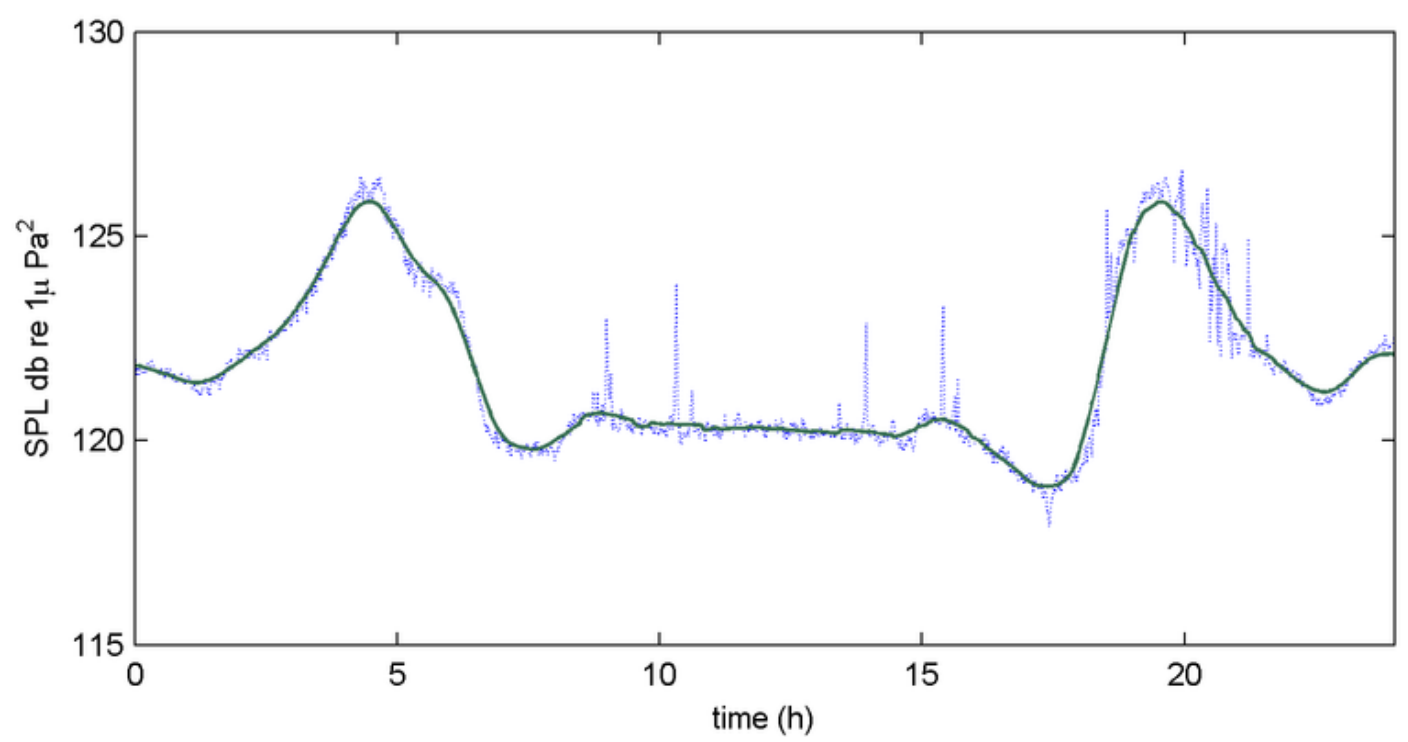

Figure 25 - Discontinuous line represents 24-h SPL curve for February 7, 2015 in XJSP; continuous line represents the smoothed 24-h SPL.

\subsubsection{Manual detection of chorus occurrence times}

Five chorus types were predominant at both studied sites, one occurring in $\operatorname{LSMSP}\left(L S_{1}\right)$ and the others $\left(X J_{1}-X J_{4}\right)$ in XJSP. Each chorus type reveals different temporal and spectral patterns, as can be seen in Figure 24. The simultaneous visual inspection of the spectrogram and the SPL curve, in specific frequency bands, was implemented as a detection criteria for determination of start, peak and end time instants for each chorus type. For choruses $L S_{1}$ and $X J_{1}$ the frequency band used was: $0.3-1 \mathrm{kHz}$; for choruses $X J_{2}$ and $X J_{4}, 0.3-1.5 \mathrm{kHz}$, and for $X J_{3} 1.5-2.0 \mathrm{kHz}$.

Figure 26 is an example of detection of time instant points for $X J_{2}$ chorus type. The time instant parameters are manually added over the SPL curve through a custom software interface, whose functioning is summarized in the following. In Figure 26 the start, peak and end time of choruses occurrence were visually recognized and their time values were annotated. Finally, the time coordinate values were then saved into a three dimensional array further statistical analysis.

\subsubsection{Cepstral analysis for striped chorus type}

It is possible to observe, in the spectrograms of Figure 24, that there are two chorus types $\left(X_{2}\right.$ and $X J_{4}$ ) where spectral peaks are uniformly separated. Figure 27 represents fish sounds reported from recordings in Australian waters (PARSONS et al., 2016a), which have spectral characteristics similar to those of chorus $X J_{2}$ and $X J_{4}$.

The frequency spacing between spectral peaks, denoted as $F_{0}$ in Figure 27 (a), is named as pulse repetition frequency (PARSONS et al., 2016a; PARSONS et al., 2016b; PARSONS; MCCAULEY; MACKIE, 2013) in literature. $F_{0}$ is the inverse of time the $\left(T_{0}\right)$ between pulses triggered by muscle contractions (MCCAULEY, 2012). As it can be seen in Figure 27, fish calls that form the choruses with spectral peak characterization are quasi-periodic signals. Thus, as explained in (OPPENHEIM; SCHAFER, 
2004), a Cepstral analysis can be used to computed the parameter $F_{0}$ for chorus types $X J_{2}$ and $X J_{4}$.
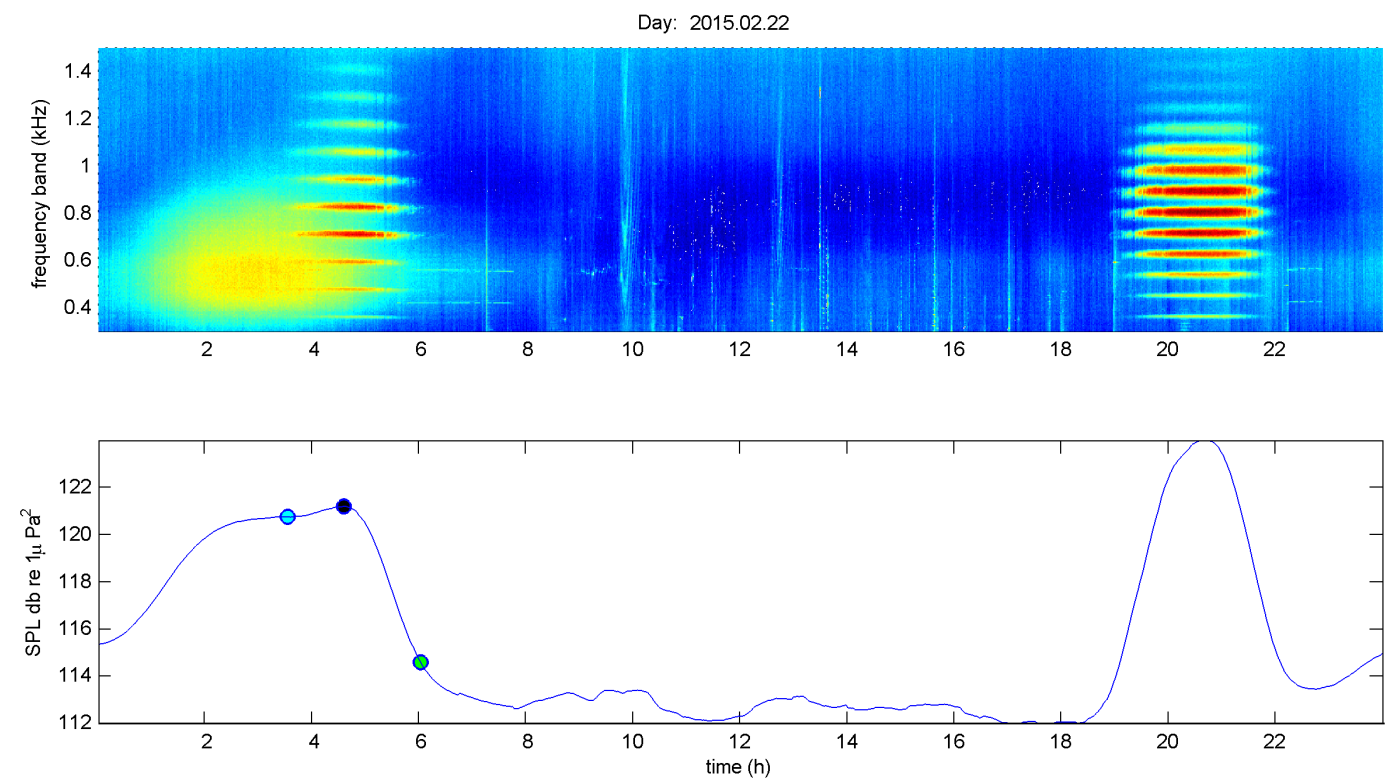

Figure 26 - Example of manual annotations of start (blue), peak (black) and end (green) of chorus XJ 2 type based on spectrogram and SPL in the frequency band: $0.3-1.5 \mathrm{kHz}$.
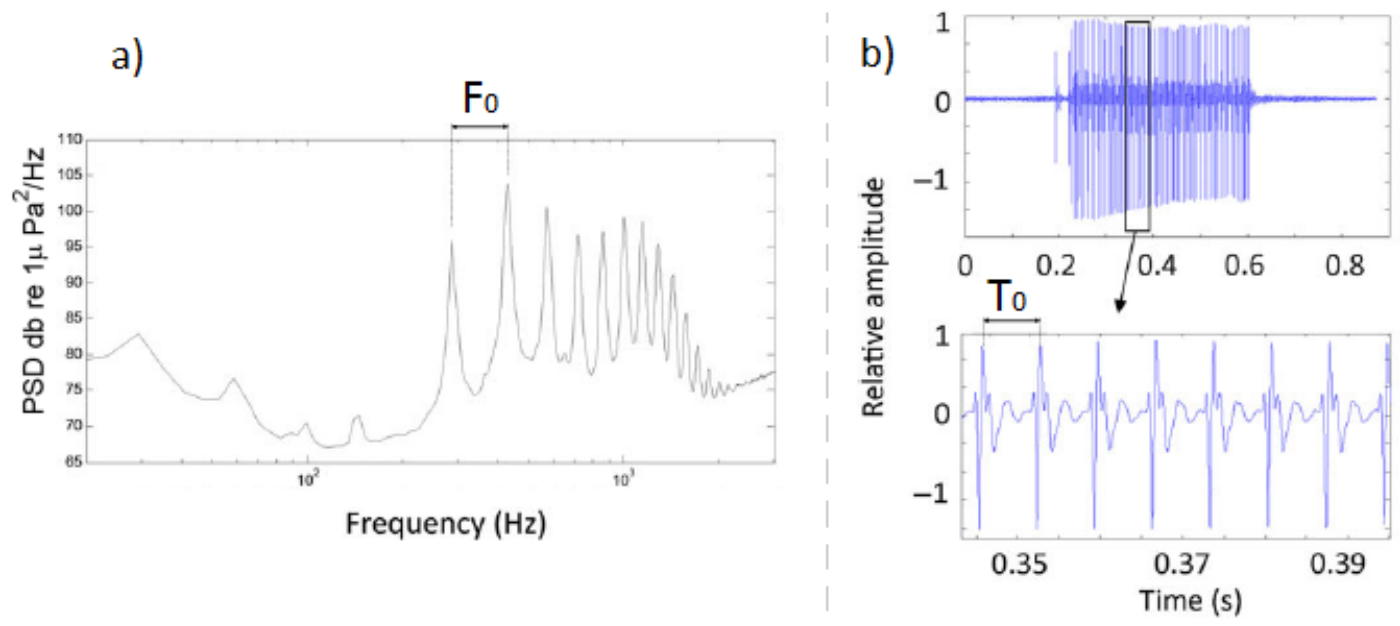

Figure 27 - PSD of example sections of a fish chorus recorded in Australia; b) waveforms and expanded waveforms of the calls for chorus represented in a). Modified from (PARSONS et al., 2016a).

The cepstrum is defined in one of its variants as the Inverse Fourier Transform (IFT) of the logarithm of the Fourier Transform (IFT) of a time waveform, $x(t)$ (OPPENHEIM; SCHAFER, 2004), as in expression 5.1.

$$
C_{p}(\tau)=\operatorname{IFT}(\ln |F T(x(t))|)
$$

The value $T_{0}$ can be computed as the first "rahmonics" appearing in the cepstrum (OPPENHEIM; SCHAFER, 2004), then $F_{0}$ is calculated as the inverse of $T_{0}$. 
Another spectral descriptor used in this work to characterize fish sounds is the - $3 \mathrm{~dB}$ bandwidth (VERFUSS et al., 2014), which will be referenced as -3dBW for the rest of this text. The parameter $-3 \mathrm{dBW}$ is better defined to be computed on smoothed PSD curves. Thus, although the smoothing would be strictly necessary only for chorus $X J_{2}$ and $X J_{4}$ a low pass lifter was applied on the respective PSD curves for all chorus types.Finally, $-3 \mathrm{dBW}$ was calculated on the resulted smoothed spectrum.

A 10 order low pass Butterworth lifter with normalized cutoff frequency set to 0.0543 was used for smoothing the spectrum.

\subsubsection{Statistical analysis of chorus characteristics}

While the temporal descriptors were determined by manual scrutiny as explained in section 5.2.2, the chorus spectral features were calculated from selected sections of Pxx matrices. A one hour time segment of the Pxx matrix, corresponding to each daily chorus type, was selected for the calculations of the dominant frequency, $-3 \mathrm{dBW}$ and and pulse repetition frequency $\left(F_{0}\right)$. The sections of Pxx matrix used to characterize each daily chorus type were selected aiming to minimize overlapping between chorus characteristics. For example, to select sections of choruses $X J_{1}$ and $X J_{2}$, were used a Pxx segment $1 \mathrm{~h}$ before the peak of $X J_{1}$ and $1 \mathrm{~h}$ after the peak of $X J_{2}$ respectively.

The box plot graphic (DECOURSEY, 2003) was used for statistical representation of the analyzed data. In this context, the calculated mean and standard deviation (SD) were taken as a measure of the central tendency and dispersion of the parameters presented in the study (DECOURSEY, 2003). Besides, it was analyzed which chorus time instants showed the highest temporal stability. For this purpose, the mean for each annotated time instant (start, peak and end) was extracted and then, through SD calculations, the daily temporal stability of choruses timings was estimated.

Next, the dominant frequency was determined as the value at which the mean PSD is the highest, during the averaged period of time. Thus, for each daily chorus a respectively value of dominant frequency was estimated and, finally, the variability in dominant frequency was evaluated for each chorus type, based on daily values.

\subsection{Results}

Figure 28 (a) summarizes the variability of start time instants and Figure 28 (b) the variability of end time instants of each chorus type.

Figure 29 (a) shows the variability of the peak occurrence times and Figure 29 (b) represents the dispersion of the chorus start, peak and end time instants. Particularly, Figure 29 (b) suggests that the peak time instant is a temporal chorus descriptor with less deviation than the start and end time instants.

Figure 30 (a), shows variations in chorus duration. This figure illustrates that, in average $L S_{1}$ is the longest chorus type and $X J_{3}$ is the shortest. 
a)

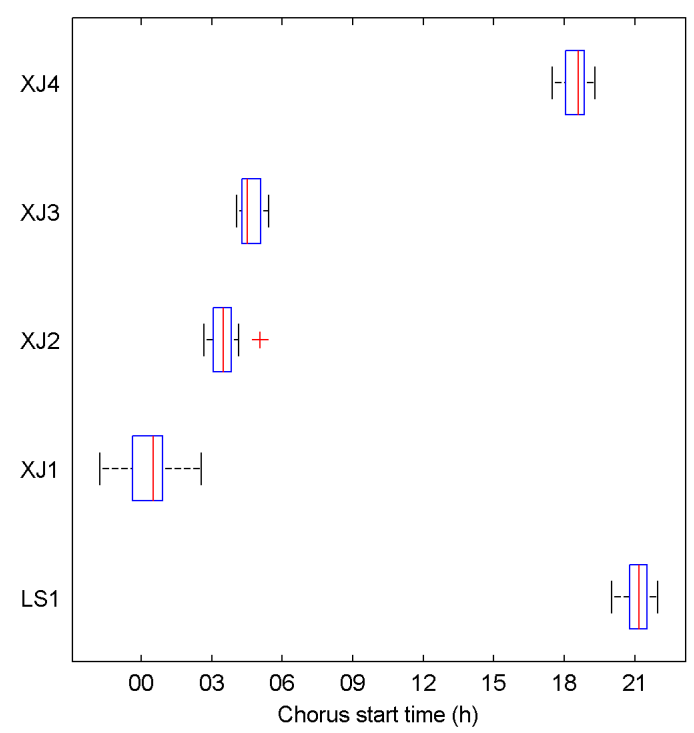

b)

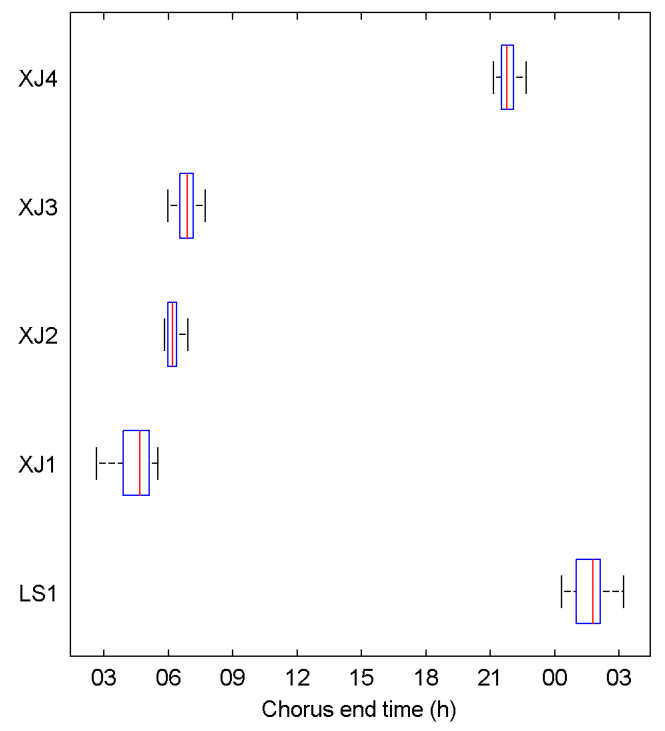

Figure 28 - a) Variation of start time for each chorus type and b) variations of end time for each chorus type.

a)

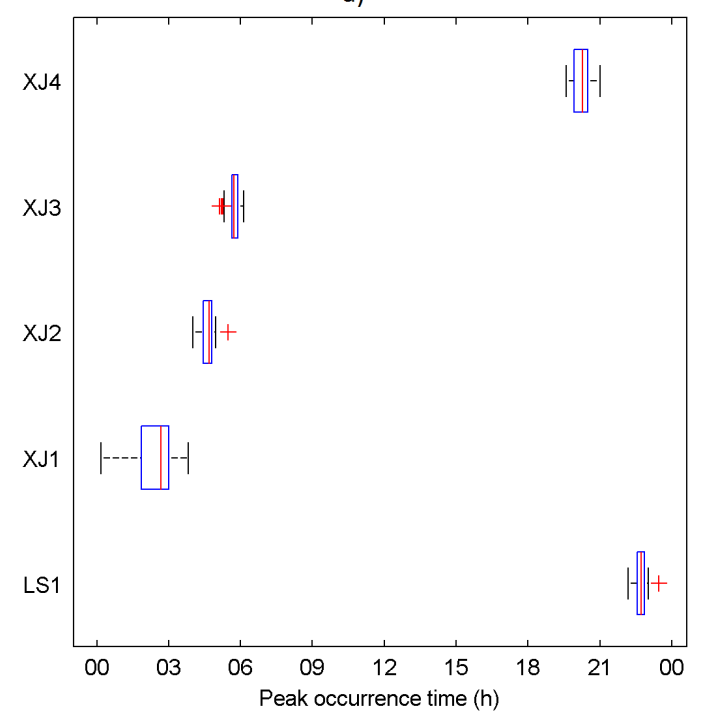

b)

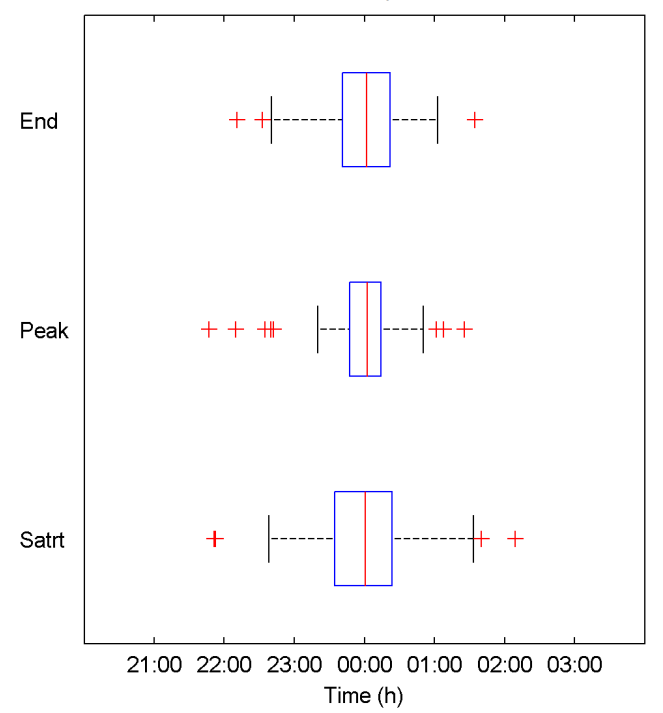

Figure 29 - a) Variation in peak occurrence time for each chorus type and b) dispersion of chorus time instants points.

\subsubsection{Spectral analysis}

Dominant frequency variations calculated on representative time slice for each daily chorus type appear in Figure 30 (b). In average the types $L S_{1}$ and $X J_{1}$, and $X J_{2}$ and $X J_{4}$ are similar in respect to dominant frequency, respectively. In order to illustrate the spectral shape for each chorus type, the mean PSD was calculated for one representative example of each type, as can be seen in Figure 31. $L S_{1}, X J_{1}$ and $X J_{3}$ show a smooth PSD curve. In contrast $X J_{2}$ and $X J_{4}$ exhibit a PSD curve with Spectral peaks. The dominant frequencies for these examples resulted $623 \mathrm{~Hz}$ for $L S_{1}, 537 \mathrm{~Hz}$ for $X J_{1}, 692 \mathrm{~Hz}$ for $X J_{2}, 1687$ $\mathrm{Hz}$ for $X J_{3}$ and $805 \mathrm{kHz}$ for $X J_{4}$. 
a)

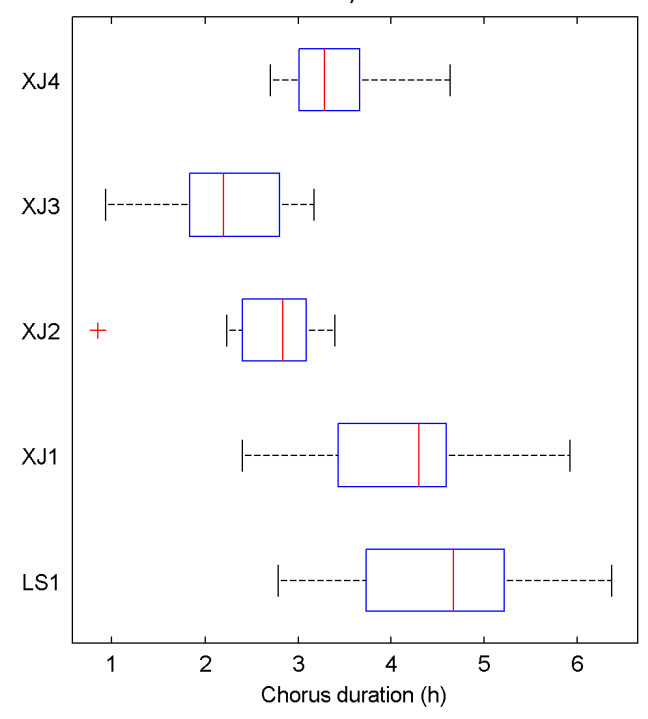

b)

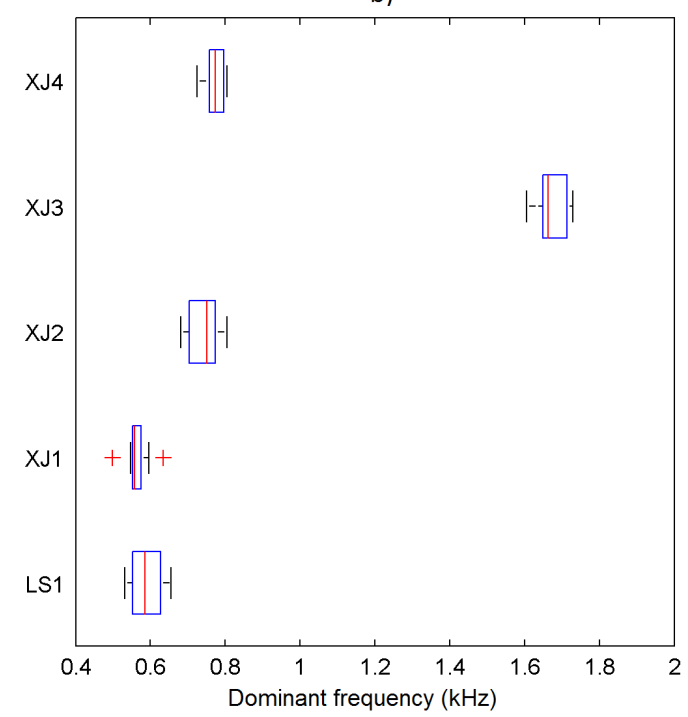

Figure 30 - a) Duration for each chorus types and b) variation in dominant frequencies.

a) LS1

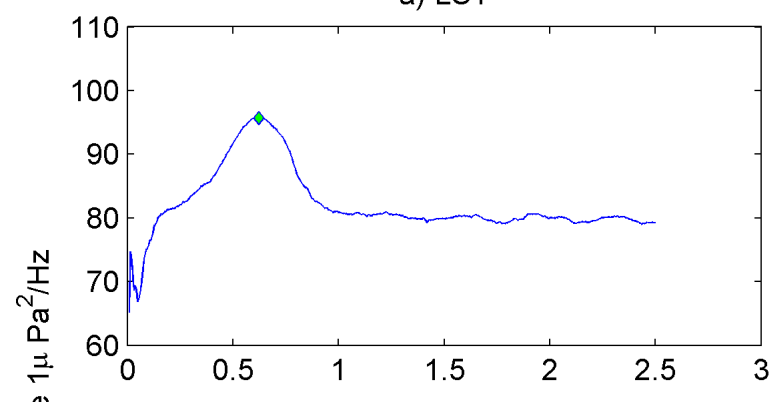

c) $\mathrm{XJ} 2$ and $\mathrm{XJ} 3$

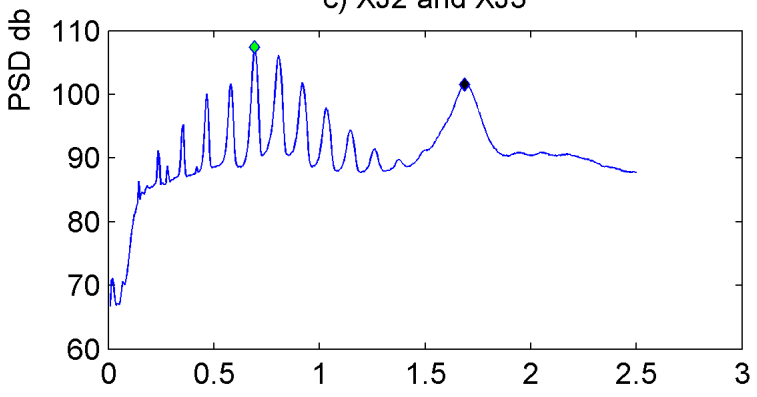

b) XJ1

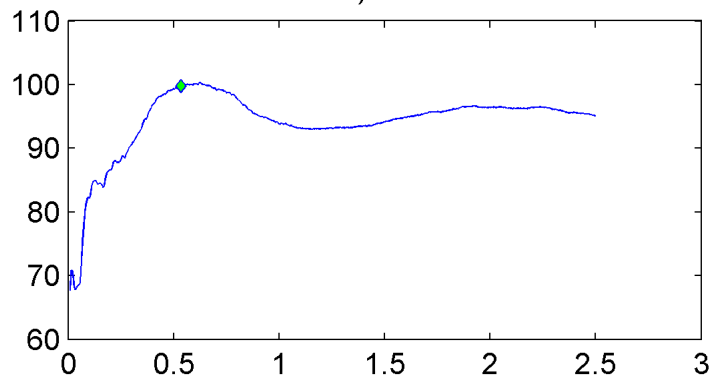

d) XJ4

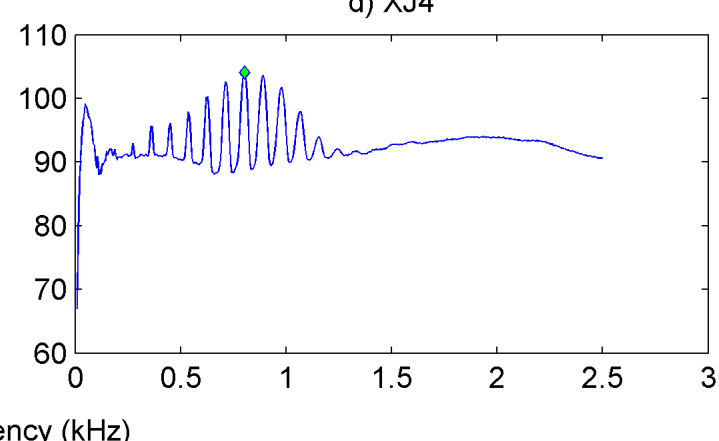

Figure 31 - Mean PSD of a representative time slice of each chorus type from a randomly selected day. The highlighted point represents the dominant frequency for the respective chorus type. The exception is for c) where dominant frequency for $X J_{2}$ appears in green, and for $X J_{3}$ in black.

In more details, choruses $X J_{2}$ and $X J_{4}$, present a main broad peak and sharper peaks, separated by constant frequency intervals. In (MCCAULEY; CATO, 2000; MCCAULEY, 2012; PARSONS et al., 2016a) fish calls with these spectral characteristics are described. For the particular example represented in Figure 31, the spectral peaks are separated by $112 \mathrm{~Hz}$ for the $X J_{2}$ case, and $88 \mathrm{~Hz}$ for the $X J_{4}$. 
The statistics presented in Figure 28 to Figure 30 are summarized in Table 6, where DF indicates dominant frequency. Except for the descriptor - 3dBW, the remaining descriptors are described in Table 6 by mean $\pm S D$ values, and for values associated with time, mean appear in $\mathrm{h}$ and $S D$ in min.

Table 6 - Statistics for chorus characteristics.

\begin{tabular}{llllllll}
\hline Chorus Type & Start $(\mathrm{h})$ & Peak $(\mathrm{h})$ & End $(\mathrm{h})$ & Duration $(\mathrm{h})$ & $\mathrm{DF}(\mathrm{Hz})$ & $F_{0}(\mathrm{~Hz})$ & $-3 \mathrm{dBW}(\mathrm{Hz})$ \\
\hline$L_{1}$ & $21: 07 \pm 32$ & $22: 42 \pm 15$ & $01: 38 \pm 44$ & $4.5 \pm 59$ & $570 \pm 38$ & - & $436-700$ \\
$X_{1}$ & $00: 23 \pm 64$ & $02: 24 \pm 56$ & $04: 28 \pm 47$ & $4.1 \pm 49$ & $537 \pm 17$ & - & $388-770$ \\
$X_{2}$ & $03: 30 \pm 31$ & $04: 37 \pm 17$ & $06: 12 \pm 16$ & $2.7 \pm 31$ & $727 \pm 40$ & $112 \pm 6$ & $592-899$ \\
$X_{3}$ & $04: 38 \pm 26$ & $05: 42 \pm 15$ & $06: 50 \pm 25$ & $2.2 \pm 41$ & $1656 \pm 34$ & - & $1588-1712$ \\
$X_{4}$ & $18: 29 \pm 28$ & $20: 14 \pm 23$ & $21: 50 \pm 24$ & $3.4 \pm 29$ & $788 \pm 42$ & $84 \pm 6$ & $657-991$ \\
\hline$S D$ & 38 & 29 & 34 & & & & \\
\hline
\end{tabular}

Also, the mean of manual annotations for start, peak and end time instants for the mean dominant frequency of each choruses types are plotted on the $24-\mathrm{h}$ mean Spectrogram, as Figure 32 shows. This graphic illustrates a good agreement between mean chorus parameters, calculated based on manually data scrutiny, and the 24 - $\mathrm{h}$ mean spectrogram.

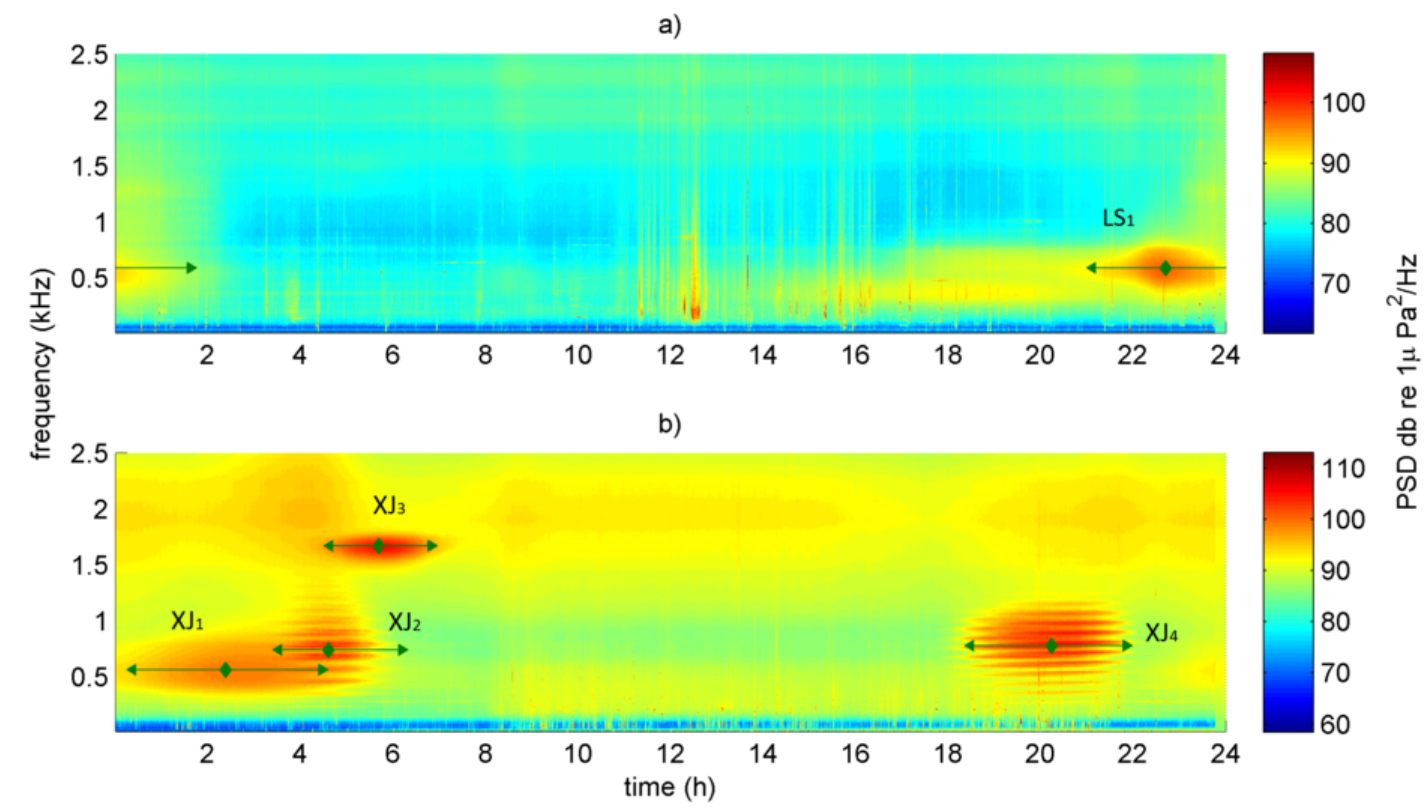

Figure 32 - 24-h mean spectrogram representing start, peak and end time instants of chorus over dominant frequency mean values, a) LSMSP and b) XJSP.

\subsection{Discussion}

Over 800 species of fish produce sounds (SLABBEKOORN et al., 2010), many of which include commercially and recreationally managed species (LOCASCIO; MANN, 2011). In general, the most intense fish sounds are associated to reproduction, and are produced by males (ROUNTREE et al., 2006). In addition, it has been reported that in some species, males adjust their calling rate according to neighbour competitors (JORDÃO; FONSECA; AMORIM, 2012), which in fact, could induce a chain reaction producing lasting choruses, like events highlighted in Figure 32. 
The findings obtained by manual determinations of chorus temporal characteristics, agree with the estimative of chorus start and end time instants based on 24-h spectrogram, as Figure 32 also illustrates. This fact validates the results presented in previous work (SANCHEZ-GENDRIZ; PADOVESE, 2016), and confirms that the 24-h mean spectrogram is an plain exploratory approach that could be useful for summarizing long-term underwater acoustic data.

From the studied sites, two groups of chorus pairs share spectral similarity, $L S_{1}$ with $X J_{1}$ and $X J_{2}$ with $X J_{4}$. The chorus type $X J_{3}$ comprises a frequency bandwidth out of reach for the other types (see Figure 32). Despite the spectral similarity of two chorus groups, there is not any kind of acoustic competition between them, because they do not share time and space occurrence in neither case. This peculiarity of avoiding competition for acoustic environment has been reported before for fish choruses (MCCAULEY, 2012). However, chorus types $X J_{1}$ and $X J_{2}$ exhibit and overlap in time and frequency, but in contrast, the manual estimated chorus peaks, are different. Presumably, the really different spectral characteristics of events $X J_{1}$ and $X J_{2}$ allow to target receptors to distinguish the desirable information.

Studies (MCCAULEY, 2012; MCCAULEY; CATO, 2000) have related the broad spectral peak of fish sounds with swim-bladder resonance frequency, and the constant frequency intervals between peaks with pulse repetitions rates. In the particular case of the present text, the analyzed acoustic events are composed by the superposition of many individual calls, therefore not assumption of source mechanisms are made. However, it is worth noting that choruses spectral patterns could be similar to spectral characteristics of individuals calls (SPRAGUE et al., 2000).

The peak time instant of daily choruses, as showed in the present paper, results a more stable temporal characteristics than start and end of chorus, as shown in Figure 29 (b), which agrees with findings presented in (LOCASCIO; MANN, 2011). The statement that peak time instant could be related to spawning and egg levels (LUCZKOVICH et al., 2008; LUCZKOVICH; MANN; ROUNTREE, 2008), reinforces the importance of reporting this temporal descriptor, even more for an study related to marine PAs. Fish sound production is related to specific behavioral activities (PARSONS et al., 2016a; PARSONS et al., 2016b); being the most intense sounds those associated with reproduction (JORDÃO; FONSECA; AMORIM, 2012; ROUNTREE et al., 2006). In this sense the survey could be used as an indicator in the study of fish reproductive behavior. Fish shoals are important ecosystem components, therefore fish shoals behavior activities could be used to monitor possible fauna degradations and potential changes (LOCASCIO; MANN, 2008).

The present study also reports variations in daily values of dominant frequency, peak interval frequency and $-3 \mathrm{dBW}$. These spectral descriptors, especially the dominant frequency could be related to several aspects. Fish sounds are typically generated by rapid movements of the sonic muscle surrounding the swim bladder. Therefore, anatomical differences between species-specific induce different sounds characteristics that could be used for species identification (MONTIE; VEGA; POWELL, 2015). As an example, the dominant frequency has been used in (LUCZKOVICH et al., 2008) to distinguish between species. Also, for the same species, studies have already related spectral variations with water temperature, salinity (MONTIE; VEGA; POWELL, 2015) and fish size (LECHNER; WYSOCKI; LADICH, 2010), only to mention some cases.

Besides the descriptors here presented, other features are also used for characterizing long-term 
fish acoustic data in literature. These features are received sound levels, the number of pulses that comprise an individual call, call duration, pulse decay, among others. However, the features described in the present work are among the main acoustic attributes used in studies on fish sounds monitoring (MCCAULEY; CATO, 2000; MCCAULEY, 2012; PARSONS et al., 2016a; PARSONS et al., 2016b).

The new data presented here is particularly useful for management purposes, since identifying the temporal, spectral or spatial variability of biological sounds is an important factor for habitat managements (LECHNER; WYSOCKI; LADICH, 2010; MONTIE; VEGA; POWELL, 2015; MOONEY et al., 2016). Especially, describing fish chorus patterns becomes relevant, since these acoustic events are related to spawning activities in most instances (LOCASCIO; MANN, 2011).

As explained in section 5.2.2, daily values of chorus occurrence times were obtained by manual scrutiny of data. Manual methods for detecting biological sounds have reported high rate of success, as for example $92 \%$ of true positive reported for manual detection of maned wolves (ROCHA et al., 2015). For the particular case of fish choruses, manual data analysis are also a common practice (PARSONS et al., 2016a). Nevertheless, it is worth noting that automatic methods are desirable for fish sound detection, especially for long-term acoustic monitoring. Automatic recognition of fish sounds is commonly based on supervised methods (MALFANTE et al., 2016; VIEIRA et al., 2015). As the name implies, supervised algorithms, need to be trained with a set of features obtained from a manually selected training set (JAMES et al., 2013), in this particular case fish sounds. Thus, the chorus descriptors here presented could be used as an input feature vector for implementing automatic recognition of fish chorus occurrence in the monitored regions.

\subsection{Conclusions}

The present paper statistically summarizes the temporal and spectral patterns for five choruses types detected in one month of continuous underwater data measurement. Box plot representation, mean and SD calculations, mean PSD, 24 - h mean spectrogram and cepstral analysis provide quantitatively and qualitative descriptors of the choruses. Concisely, the work provides daily values of start, peak and end time instants of choruses, as well as spectral descriptors such as the dominant frequency, pulse repetition frequency and the frequency bandwidth. These findings could be used for the assessment of trends of soundscape biotic components of the studied sites. Additionally, the reported descriptors may be used as features for species identification, due by comparison with captive fish or with literature reports.

The method used to obtain chorus temporal descriptors was based on simultaneous manual scrutiny of Spectrograms and SPL curves. Although it allowed distinguishing between overlapping choruses presented in data here analysed, a shortcoming could arise for analysing highly overlapped events. An optional approach relies on machine learning methods for automatic chorus detection. In this sense, the descriptors could be used as an input vector feature for automatic detection algorithms, which are useful for long-term passive acoustic monitoring. Traditional methods for fisheries research are labor intensive and expensive, sometimes being not practical for long-term surveys. With recent advances in data storage devices, software and related technology, passive acoustic monitoring arises as an important cost-effective tool to be applied to management of protected areas and fisheries studies. 



\title{
ANALYZING BIOLOGICAL CHORUSES FROM LONG-TERM PASSIVE ACOUSTIC MONITORING IN NATURAL AREAS
}

\begin{abstract}
Long-term passive acoustic monitoring can provide important insights on the study of biological choruses, which represent a key component of natural environments. Nowadays, the development of methods for analysis and visualization of large acoustic datasets is an active area of research. In this context, the present paper addresses how the traditional computation of spectrograms and Sound Pressure Levels (SPL) could be used for analyzing large sound datasets. Additionally, a visualization tool named here as SPL-Gram and a method for automatic detection of trends in dawn and dusk choruses are presented. The dataset used as study case represents 3 months of underwater sound collected in a marine wildlife refuge in southern Brazilian coast. Results reveal events with strong daily periodicity, originated by fish choruses in the frequency band from $0-2 \mathrm{kHz}$, and, in the higher frequencies, reflecting acoustic activity of crustaceans. The reported periodicities show a marked relation with sunrise and sunset through the studied period, thus revealing circadian cycles presented in the monitored environment. The proposed methodology is not only easy for implementation, but also proves to be valuable in the description of daily and seasonal patterns of biological choruses in large acoustic datasets.
\end{abstract}

Keywords: Soundscape ecology, biological choruses, long-term passive acoustic monitoring, Alcatrazes archipelago wild life refuge.

\subsection{Introduction}

\subsubsection{Soundscape ecology, a relevant property of ecosystems}

The compositions of sounds that emerge from an environment has been named as soundscape, which is described in the field of soundscape ecology proposed by (PIJANOWSKI et al., 2011b; PIJANOWSKI et al., 2011a). The soundscape is based on the sounds related to geophony (geological sounds), biophony (biological sounds), and anthropophony (human-produced sounds) (ERBE et al., 2015; 
FARINA; JAMES, 2016; PIJANOWSKI et al., 2011b).

The soundscape of a particular habitat is strongly linked to its dynamics and local fauna, being an important indicator of the ecosystem health and quality (JOO et al., 2007; PIJANOWSKI et al., 2011b). In this scenario, acoustic information represents a proxy for comprehension of environmental changes at daily and seasonal scales, biological diversity and species distribution (BUSCAINO et al., 2016; FARINA; JAMES, 2016). Especially, biological choruses could be a major contributor of soundscape for natural areas (ERBE et al., 2015; LOCASCIO; MANN, 2011; PIJANOWSKI et al., 2011b). Describing the daily and seasonal patterns of biological chorus can provide insight into the timing of species behaviors (GAGE; AXEL, 2014; LOCASCIO; MANN, 2011), thus enabling assessment of environmental changes due to anthropogenic or natural factors (BUSCAINO et al., 2016).

\subsubsection{The challenge of summarizing and visualizing large acoustic datasets}

Nowadays, technology allows collecting environmental sounds for periods of months or even uninterruptedly, by using autonomous or cabled acoustic systems respectively. In this context, Passive Acoustic Monitoring (PAM) systems generate a huge and complex amount of data (TOWSEY et al., 2014b; TOWSEY; PARSONS; SUEUR, 2014), from which extracting relevant information represents a complex task. In fact, several methods, as for example the acoustic indices (HARRIS; SHEARS; RADFORD, 2016; TOWSEY et al., 2014a) have been recently developed to assist in the analysis of these big datasets. These procedures can be considered useful approaches, but their use is quite complex due to a diverse and non-uniform range of applications. Though several dozen of acoustic indices have been proposed over the last decade, the ecological relevance and efficacy of these indices are still unclear (ELDRIDGE et al., 2016). In contrast, traditional metrics such as spectrograms and Sound Pressure Levels (SPL) are well-established and still valuable techniques that could be effectively employed to explore large acoustic datasets.

This work addresses the use of median 24-h spectrograms and daily 24-h SPLs represented by means of color maps images to summarize and visualize long-term acoustics recordings. The use of these metrics, in conjunction with automatic detection of trends in dusk and dawn choruses, constitutes the proposed methods, which could be a valuable tool both for either terrestrial or aquatic long-term monitoring.

\subsubsection{Dataset used as case study: 3 months of continuous recordings in a marine wildlife refuge}

The present study describes three months of continuous underwater sound records from a marine natural reserve (HOFF; FIGUEIRA; ABESSA, 2015), in the southwest Brazilian coast, the Alcatrazes Archipelago Wild Life Refuge, created in August 2016. The underwater acoustic monitoring and analysis presented in this paper are parts of a pioneer underwater study that has been conducted in this area of Brazilian waters. 


\subsection{Materials and Methods}

\subsubsection{The passive monitoring system and its deployment}

An autonomous passive monitoring system (OceanPod 3.0), was deployed at the measuring site, represented in Figure 33. The equipment allows data storage in Secure Digital (SD) memory cards, managing a maximum of four slots. Device autonomy depends on the recording configuration: sample frequency, scheduling and power of the used battery pack.

The acoustic signal data was collected from March $7^{\text {th }}$ to June $7^{\text {th }}$, 2016, totalizing 93 days of continuous recordings. The acquisition system used $24 \mathrm{kHz}$ sampling rate ( $\mathrm{fs}$ ), 16 bit resolution, and the

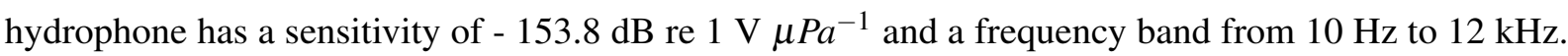
Data was continuously stored in 4 SD cards of $128 \mathrm{~GB}$ each, in wav files of 15 min durations. With the described system configuration, the volume of collected data was approximately $390 \mathrm{~GB}$.

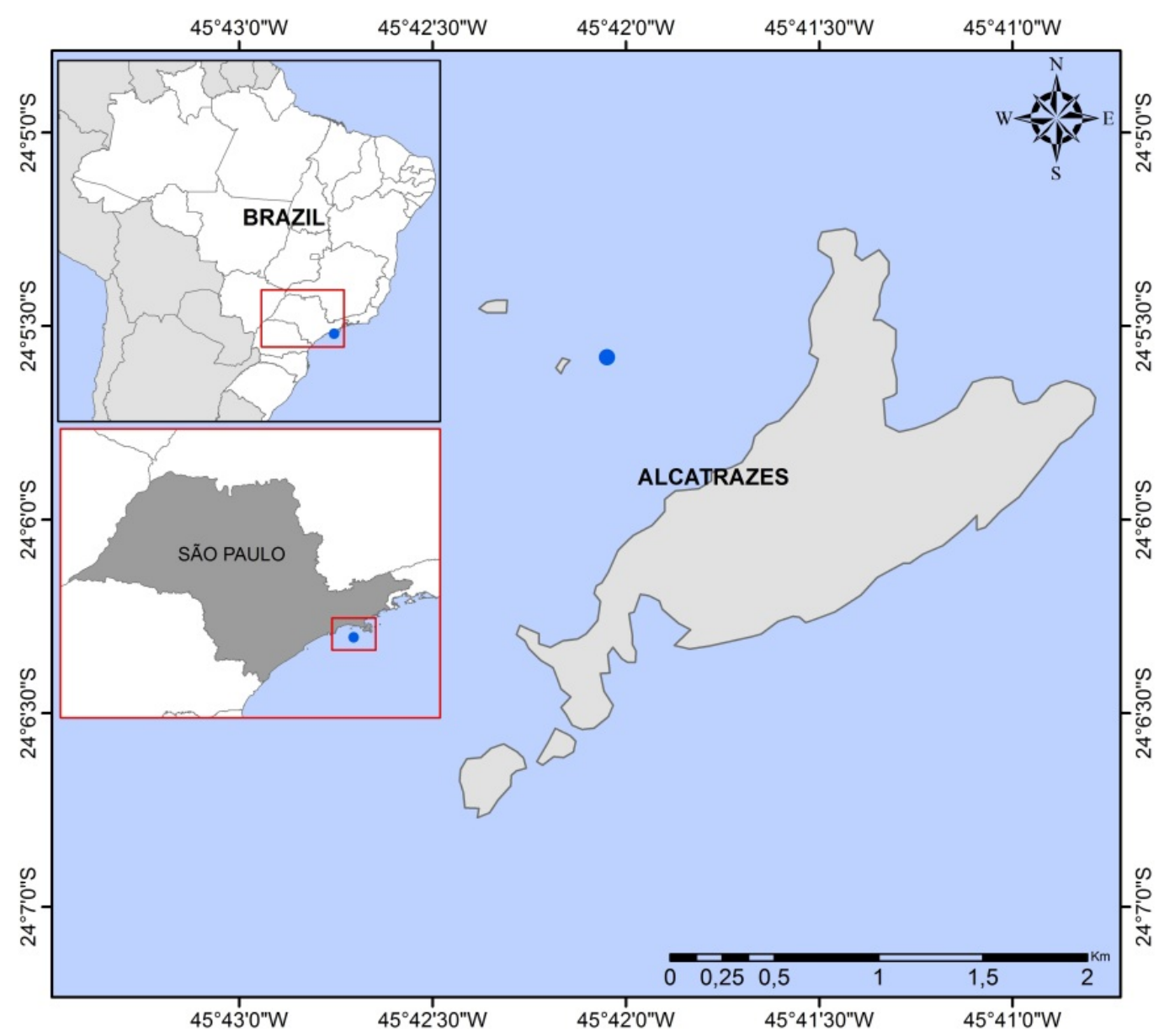

Figure 33 - Alcatrazes island localization and hidrophone position (circular marker).

\subsubsection{Data analysis}

The signal processing analysis, in this work, is based on the Power Spectral Density (PSD) (PROAKIS; MANOLAKIS, 2007) estimation of the daily acoustic data sets. In order to accomplish that, 
it was used the Welch method (WELCH, 1967) with 1-s Hamming window, 1025 frequency points, $50 \%$ of overlap, with 60-s temporal signal segments. Therefore, with these parameters, time resolution is 60 seconds and frequency resolution is $12.2 \mathrm{~Hz}$. The parameters for calculating PSD were selected aiming to facilitate comparisons with others underwater monitoring studies (MERCHANT et al., 2014; JORDÃO; FONSECA; AMORIM, 2012; COQUEREAU et al., 2016; PARSONS et al., 2016a; PARSONS et al., 2016b) and to obtain an appropriated time-frequency spectrogram resolution for the present analysis.

The processing resulted PSD matrices are named here as $\operatorname{Pxx}(n, m, k)$, been $n, m$ and $k$ minute of day, frequency and number of day indexes respectively.

\subsubsection{Selection of frequency bands for SPL calculation}

For soundscape analysis, a common practice is to divide the spectrum by frequency bands (STAATERMAN et al., 2014). For the present study, the range of frequencies between 0 - $2 \mathrm{kHz}$ was designated Low frequency Band (Low-FB), and that between 2 - $12 \mathrm{kHz}$, High Frequency Band (High-FB). It is possible to state from literature (BUSCAINO et al., 2016; STAATERMAN et al., 2014), and from our own observations (SÁNCHEZ-GENDRIZ; PADOVESE, 2016) that Low-FB comprises most of the sounds produced by fish. On the other hand, High-FB is dominated by crustacean sounds in many mid-to-low latitude coastal areas worldwide (BOHNENSTIEHL; LILLIS; EGGLESTON, 2016; STAATERMAN et al., 2014).

Also, the SPL values calculated in the selected frequency bands (Low-FB and High-FB) were used to explore the existence of an occasional relation between acoustic activity and moon phases.

\subsubsection{Averaging daily records}

Averaging metrics, calculated for daily periods, are commonly used and recommended to summarize underwater soundscapes (ROBINSON; LEPPER; HAZELWOOD, 2014; SANCHEZ-GENDRIZ; PADOVESE, 2016; TOWSEY et al., 2014b). The present study calculated the 24-h Spectrogram and 24-h SPL for each recorded day. Then, two different averaging metrics, the mean and the median, were used to average the daily Spectrograms and the SPLs of monthly periods.

\subsubsection{SPL in frequency bands and its representation as SPL-gram images}

For the SPL, a moving average filter (SMITH, 1999) was applied to smooth the curve in order to eliminate the transients sounds caused by boats and ships. A window length of $1 \mathrm{Hr}$ was selected for the filter. Figure 34 (a) exemplifies the application of that kind of filter on 24-h SPL in the Low-FB. The discontinuous line represents SPL without filtering and the continuous one represents smoothed SPL. This figure confirms that the response of the filter removes the transients in the signal and, at the same time, preserves the slow variations that could be related to fish choruses. Based on this fact, the smoothed SPL was used in this study to characterize the sound levels related to fish chorus, and for the rest of this text, the smoothed SPL will be identified by SPL simply, unless otherwise noted.

In order to compact the visualization of biotic activity, a representation named here as SPL-gram is proposed. By means of this representation, acoustic trends in the SPL over a large time period (weeks, 
months...) can be visually detected. In order to construct the SPL-gram image, each daily SPL curve, both in Low-FB and High-FB, was converted to a color-map bar respectively (see Figure 34 (b)) to be inserted vertically on a colored image map. The grouping of all color bars in this map generates a graphic that forms the SPL-gram, such as can be seen in section 6.3.4.

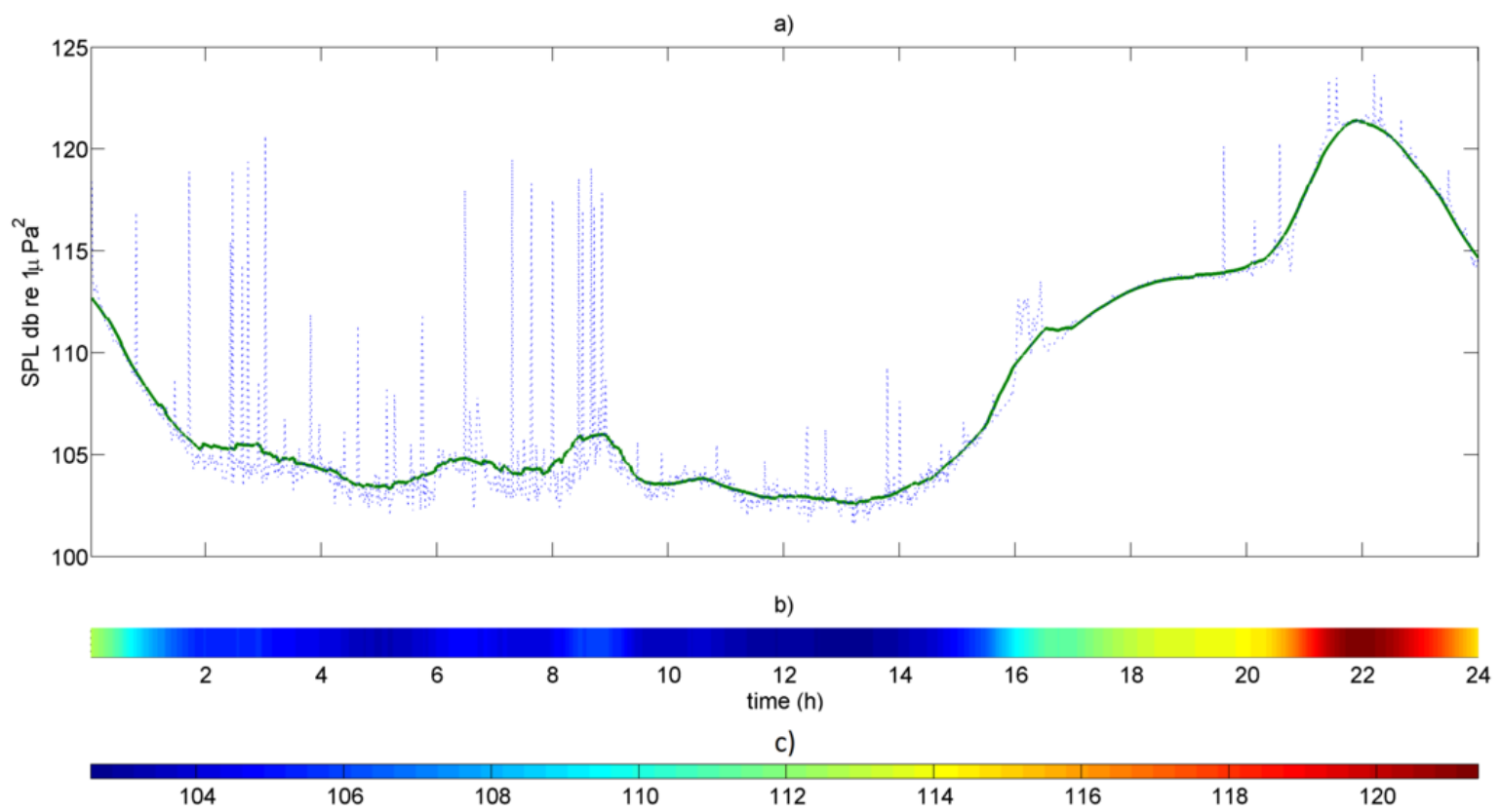

Figure 34 - Representation of SPL curve converted as color-map bar; a) Low-FB SPL calculated for May $6^{\text {th }}, 2016$; b) The color-map bar referent to Low-FB SPL in a); c) range of used colors and their respective range of SPL values for this particular example.

\subsubsection{Automatic detection of dawn and dusk chorus activities}

It is well known that biological choruses in natural areas follow daily (SANCHEZ-GENDRIZ; PADOVESE, 2016) and seasonal patterns (BUSCAINO et al., 2016; STAATERMAN et al., 2014), and, in general, are strongly correlated with sunrise and sunset (PARSONS et al., 2016a; FARINA; JAMES, 2016). Based on that fact, median 24-h SPL in Low-FB and in High-FB were used to define a search space for automatic detection of dawn and dusk chorus activities. In order to choose the search space, the highest SPL local maximum from the reference point (sunrise or sunset) was determined. Then, the difference in time, $d$, between the occurrence of the local maximum and that of the reference point was determined. Finally, the search space for each daily reference point was defined as the set of points at a distance $\mathrm{D}=2 \mathrm{~d}$ from the desired reference point. The sing of $\mathrm{d}$ defines if the search space includes the points before (-) or after (+) the reference point. Figure 35 (a) exemplifies the procedure used to determine the search space for detection of dusk choruses activity in Low-FB.

Two different methods were evaluated for detecting dawn and dusk chorus activities over Low-FB and High-FB SPL curves. Both methods worked on the same predefined search space, which was defined by two fixed points $P_{1}$ and $P_{2}$ (see Figure 35 (b)), with $P_{1}$ located at a desired time instant (sunrise or sunset) and $P_{2}$ located at time distance $\mathrm{D}$ from $P_{1}$. The proposed methods, were named here as Maximal Area Triangulation (MaxAT) and Local maximum (LoMAX). 
In order to select the chorus "timing indicator", by using the MaxAT, a recursive computation is used. In this case, it is employed a family of triangles, which vertices $P_{1}, P_{2}$, and $P_{3}$ are located on SPL curve, being $P_{3}$ a moving point that can be displaced over the SPL curve within the search space. The $P_{3}$ position forming the largest triangle area is selected as a chorus "timing indicator", $P_{\text {MaxAT }}$ (Figure 35 (b), green point).

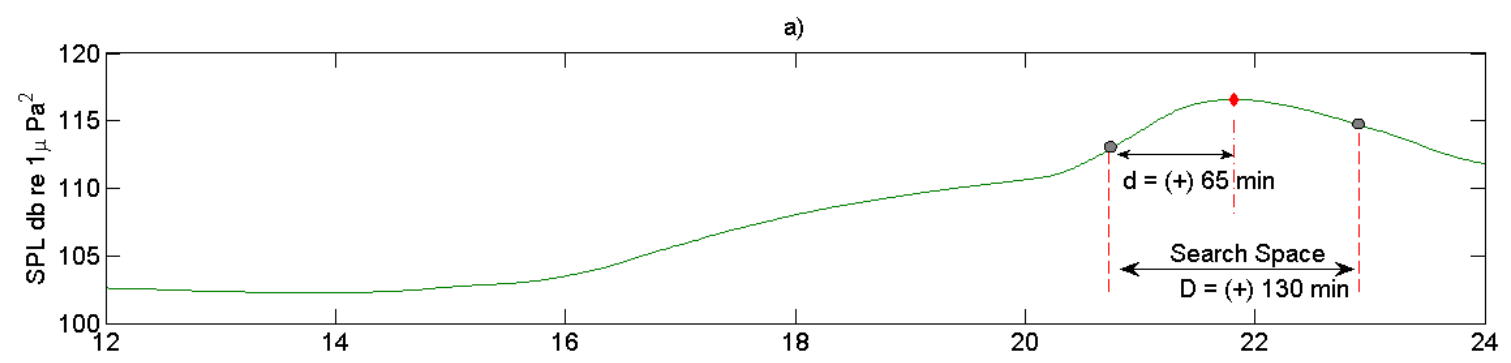

b)

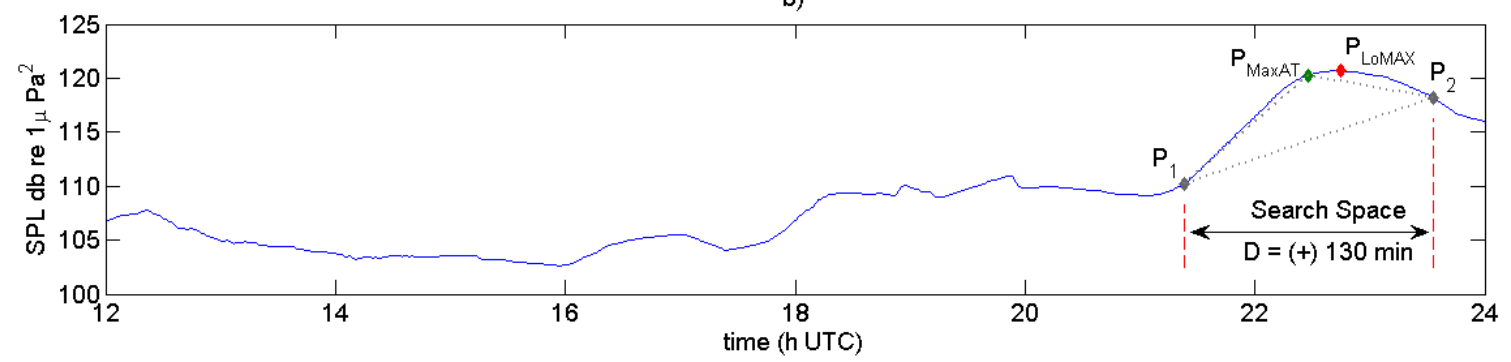

Figure 35 - Representation of the procedure used to detect dawn and dusk chorus activities, a) determination of the search space over median Low-FB SPL curve for dusk chorus activity detection, b) an example of determination of dusk timing indicator by both MaxAT $\left(P_{\text {MaxAT }}\right)$ and LoMAX $\left(P_{\text {LoMAX }}\right)$ methods.

On the other hand, in order to detect the chorus "timing indicator", by using the LoMAX method (Figure 35 (b), red point), it is calculated the largest local maximum $P_{\text {LoMAX }}$ within the search space. Thus, in the search space a point $P_{j}$ was considered a local maximum if $P_{j}-P_{j-1}>0$ and $P_{j+1}-P_{j}<0$.

From the time values calculated by both methods $\left(P_{\operatorname{Max} A T}\right.$ and $\left.P_{\text {LoMAX }}\right)$, were determined the time differences respect to sunrise and sunset. Then, the mean of the differences were computed and subtracted from the values detected by the described methods, in order to obtaining adjusted values. The plotting over sunrise and sunset of the adjusted values and the computation of their standard deviations were used to select which method reports better performance.

The detected dawn and dusk chorus timings, determined by selected method, were also plotted over the SPL-gram images, in order to assess the mutual correspondence between automatic detection of chorus activities and a visual detection, as can be seen in section 6.3.4.

\subsection{Results and discussion}

\subsubsection{SPL series in low and high frequency bands}

Figure 36 shows the Low-FB SPL and High-FB SPL curves for the studied period, the figure illustrates a significant deviation in SPL values in both frequency bands between May $19^{\text {th }}$ to May $21^{\text {th }}$. 
This peculiar event was related with a research vessel that remained stranded in the proximities of the hydrophone with the aboard machinery turned-on. The peaks of Low-FB SPL oscillate through the analyzed period: this particularity does not appearing in the high frequency band or being less evident, excepted for certain days.

A closer look at the SPL curves is represented in Figure 37, which corresponds to three days of recrding between April $10^{\text {th }}$ to April $12^{\text {th }}$. From this figure it is possible to see one daily prominent peak in the Low-FB and two daily peaks in High-FB. The factors that seem to trigger these daily periodical peaks are addressed in section 6.3.2.

Some papers have reported that fish-produced sounds can be related to moon phases (PARSONS et al., 2016a; RADFORD et al., 2008; STAATERMAN et al., 2014). For that reason, moon phases were plotted over the Low-FB SPL curve, see Figure 38. In addition, values of SPL were grouped by frequency bands, moon phase and time (day or night).

a) Low-FB SPL
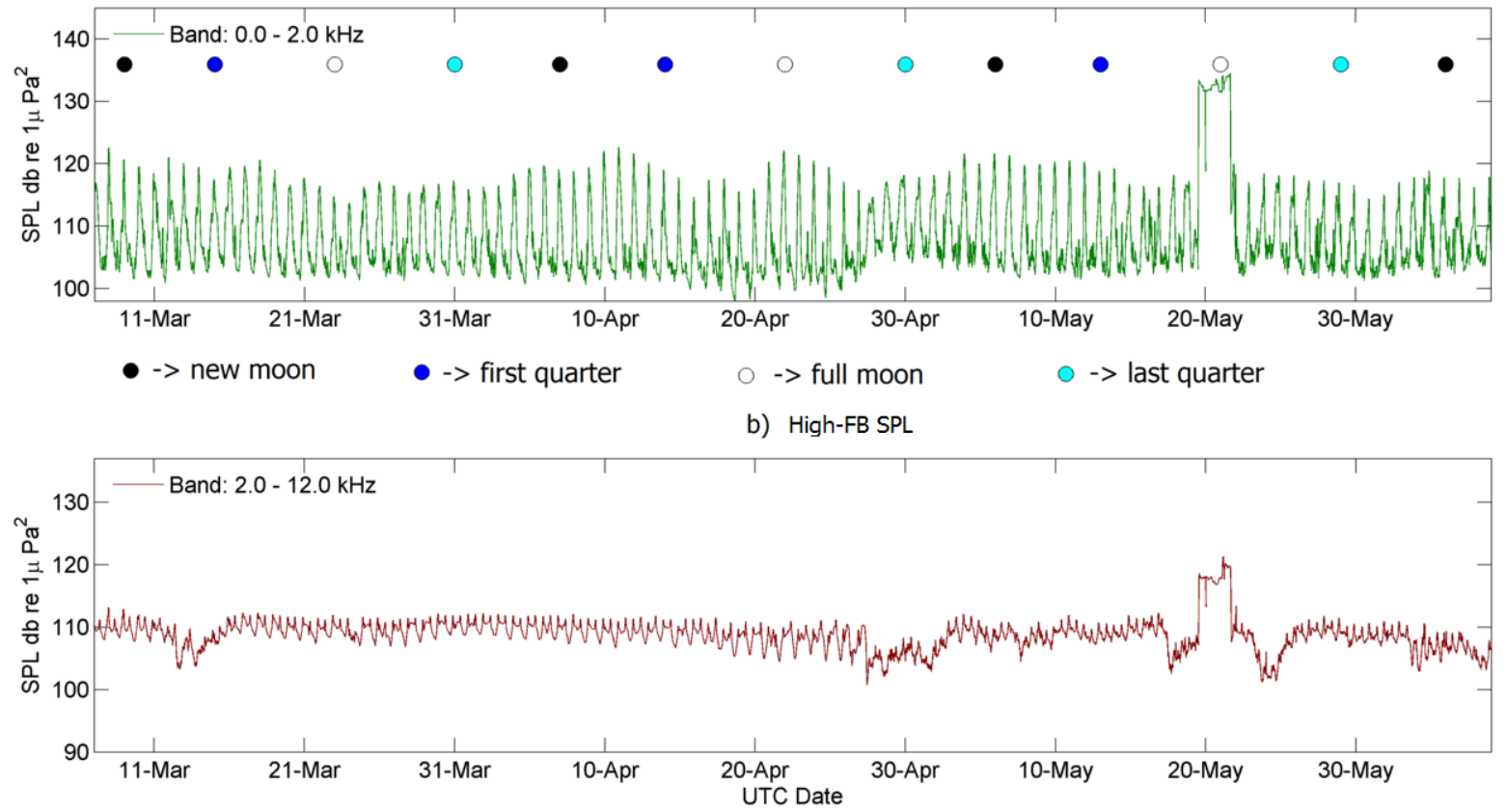

Figure 36 - SPL in selected frequency bands calculated for underwater sounds recorded at Alcatrazez Wildlife Refuge from March $7^{\text {th }}$ to June $7^{\text {th }}$, a) Low-FB SPL: $0-2 \mathrm{kHz}$; b) High-FB SPL: $2-12 \mathrm{kHz}$.

As it can be inferred, from Figure 36 and Figure 38, there were not an evident relation of Low-FB SPL with moon phases.

Similar as reported by other studies (BUSCAINO et al., 2016; MCCAULEY; CATO, 2000; STAATERMAN et al., 2013; STAATERMAN et al., 2014), night values are relatively higher than daylight values, being the difference more remarked for Low-FB, where the biological sounds are concentrated mainly. At night, visual communication is dificult underwater; which could be related to the fact that more species become more acoustically active during nigth periods. 

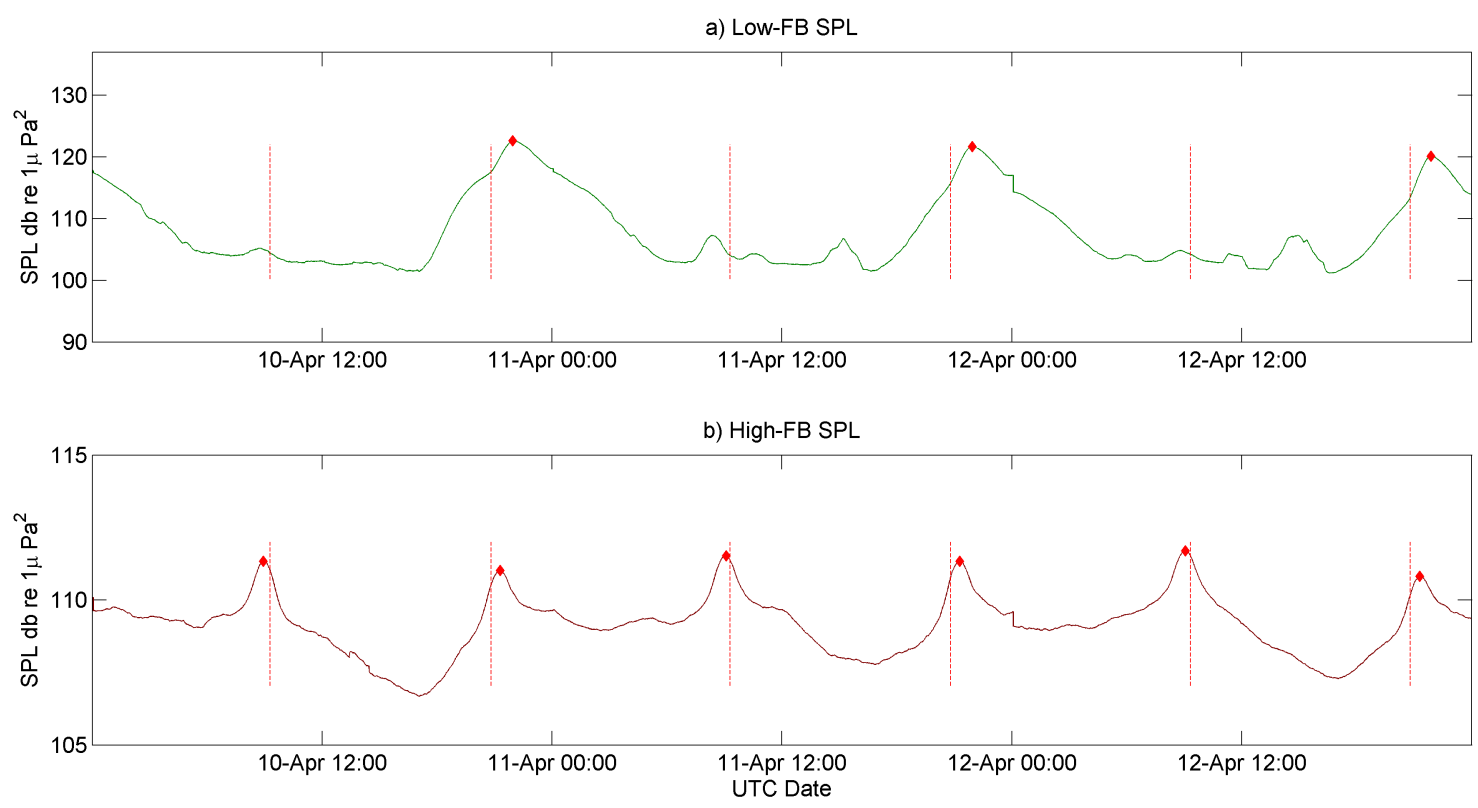

Figure 37 - SPL in selected frequency bands calculated for underwater sounds recorded at Alcatrazez Wildlife Refuge from April $10^{\text {th }}$ to April $12^{\text {th }}$, a) Low-FB SPL: 0 - $2 \mathrm{kHz}$; b) High-FB SPL: 2 - $12 \mathrm{kHz}$. Dashed red lines indicate the sunrise and sunset, the red points represents daily peaks.
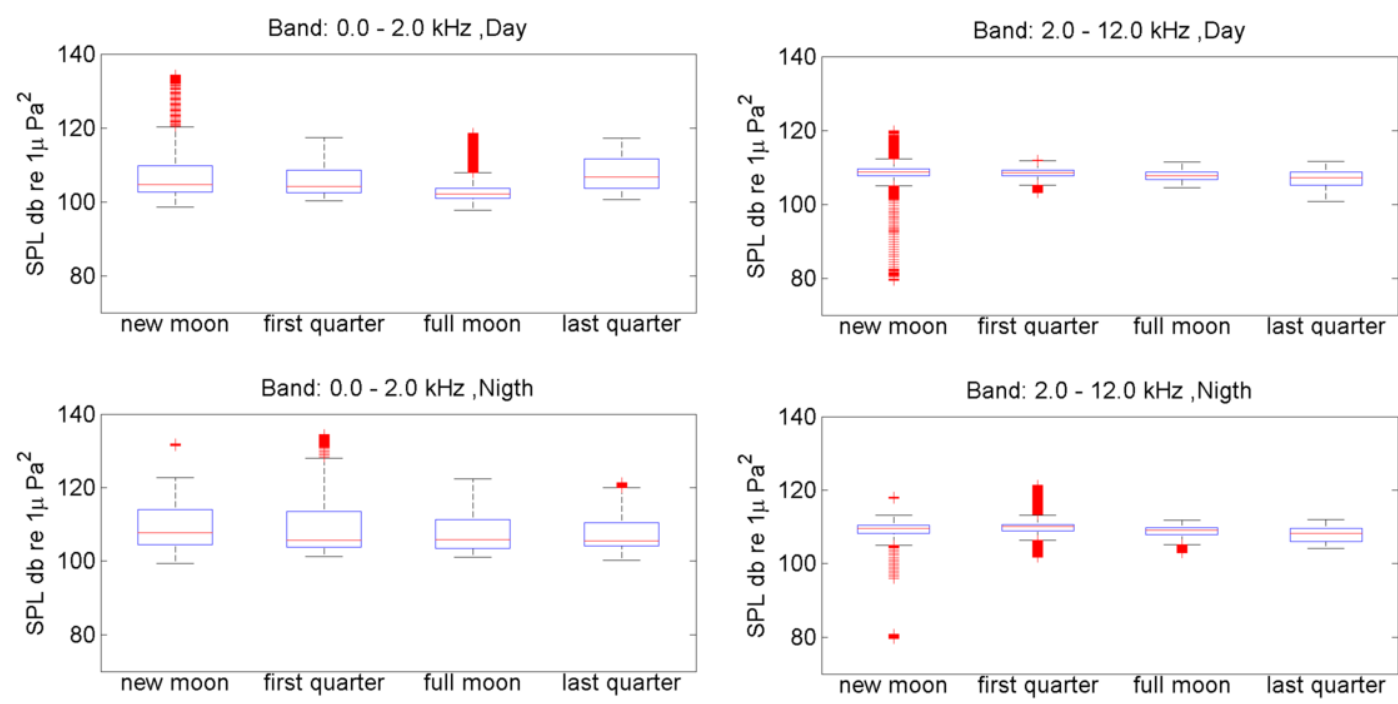

Figure 38 - SPL grouped by frequency bands and moon types.

\subsubsection{Averaging 24-h Spectrograms and 24-h SPL}

The 24 - $\mathrm{h}$ mean spectrogram could be used to summarize daily patterns of acoustic environments. Though the mean average is commonly used, it is susceptible to strong bias from outliers values (MERCHANT et al., 2012). Figure 36 shows an atypical acoustic activity during the month of May, which was originated by a stranded vessel.

Figure 39 illustrates the use of the mean spectrogram and SPL to summarize one month of 
acoustic activity. The mean average is dominated by the high acoustic energy emitted by the vessel between May $19^{\text {th }}$ to May $21^{\text {th }}$. From Figure 39, it is not possible to see any acoustic event other than the vessel noise, even when this noise lasted less than $1 / 10$ of the averaged period. For this reason the 24 $\mathrm{h}$ median average was preferred over the mean to summarize the patterns of soundscape, since outliers affect the median less.
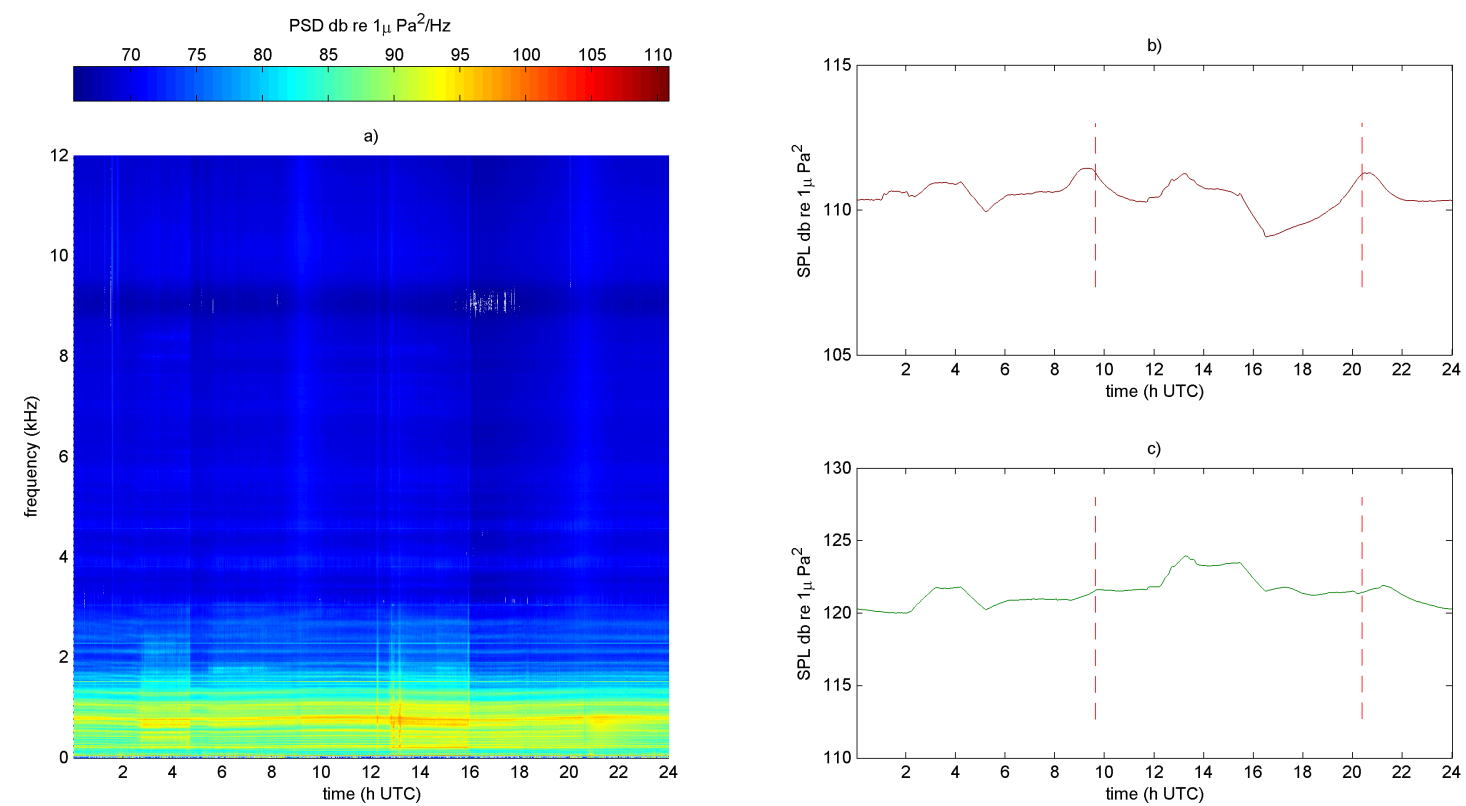

Figure 39 - Average soundscape summarization for May $8^{\text {th }}$ June $7^{\text {th }}$; a) mean 24 - h spectrogram, b) mean 24-h Low-FB SPL, c) mean 24-h High-FB SPL.

The monthly median averages are represented in Figures 40, 41 and 42. Figures 40 (a), 41 (a) and 42 (a) illustrate the spectrogram, while Figures 40 (b), 41 (b) and 42 (b) and, Figures 40 (c), 41 (c) and 42 (c) show the High-FB and Low-FB SPL respectively. Dashed red lines in parts (b) and (c) indicate the mean value of sunrise and sunset for the averaged period; the red points are the highest local maxima in the neighborhood of sunrise $\left(\right.$ Peak $\left._{s r}\right)$ and sunset $\left(\right.$ Peak $\left._{s s}\right)$.

A common characteristic for the three studied months is that, in the High-FB, median average highlights acoustic events, near sunrise and sunset. According to their broadband spectral patterns, illustrated in monthly median spectrograms, these events seem to be related to crustacean noise (BOHNENSTIEHL; LILLIS; EGGLESTON, 2016; COQUEREAU et al., 2016; STAATERMAN et al., 2014). For example, studies reported that snapping shrimps (BOHNENSTIEHL; LILLIS; EGGLESTON, 2016; STAATERMAN et al., 2014) could present these time-frequency features also with daily periodic patterns. However, the moment of the day with highest activity could be dependent of the site (BOHNENSTIEHL; LILLIS; EGGLESTON, 2016). The increase of acoustic activity in High-FB some minutes before sunrise and after sunset could be a distinctive ecological characteristic of the monitored ecosystem. In Low-FB, the main event attains its higher amplitude after sunset and last until before dawn, decreasing its duration in early hours as the daylight time decreases from March to June, as it can be seen by inspecting successively Figures 40, 41 and 42. The events in Low-FB, which occur daily near sunset, appear to be originated by fish choruses. These events have spectral and temporal patterns similar to fish sounds documented 
in another marine protected area (SANCHEZ-GENDRIZ; PADOVESE, 2016; SANCHEZ-GENDRIZ; PADOVESE, 2017), also located in the southwest Brazilian sea.
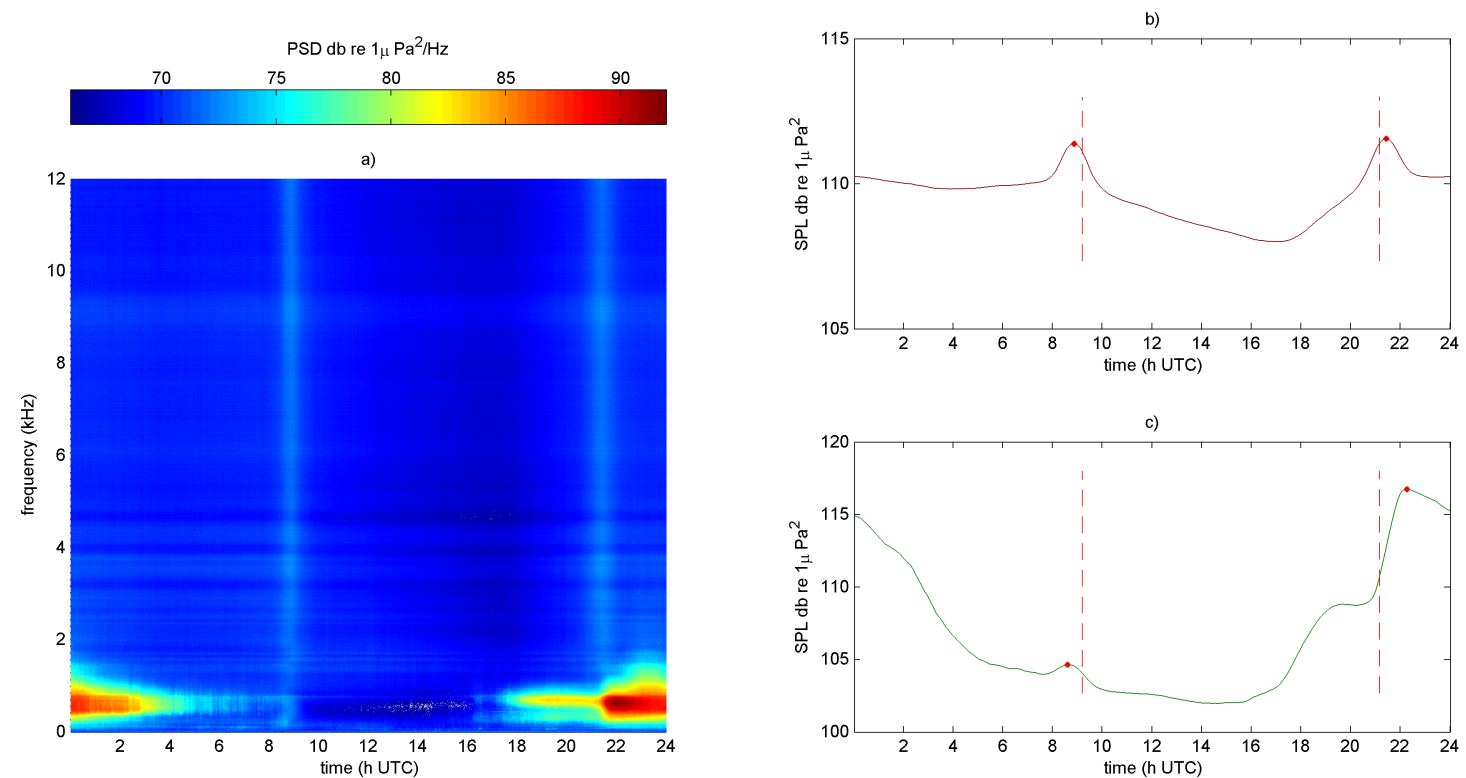

Figure 40 - Average soundscape summarization for March $7^{\text {th }}$ - April $6^{\text {th }}$; a) median 24 - h spectrogram, b) median 24-h Low-FB SPL, c) median 24-h High-FB SPL.
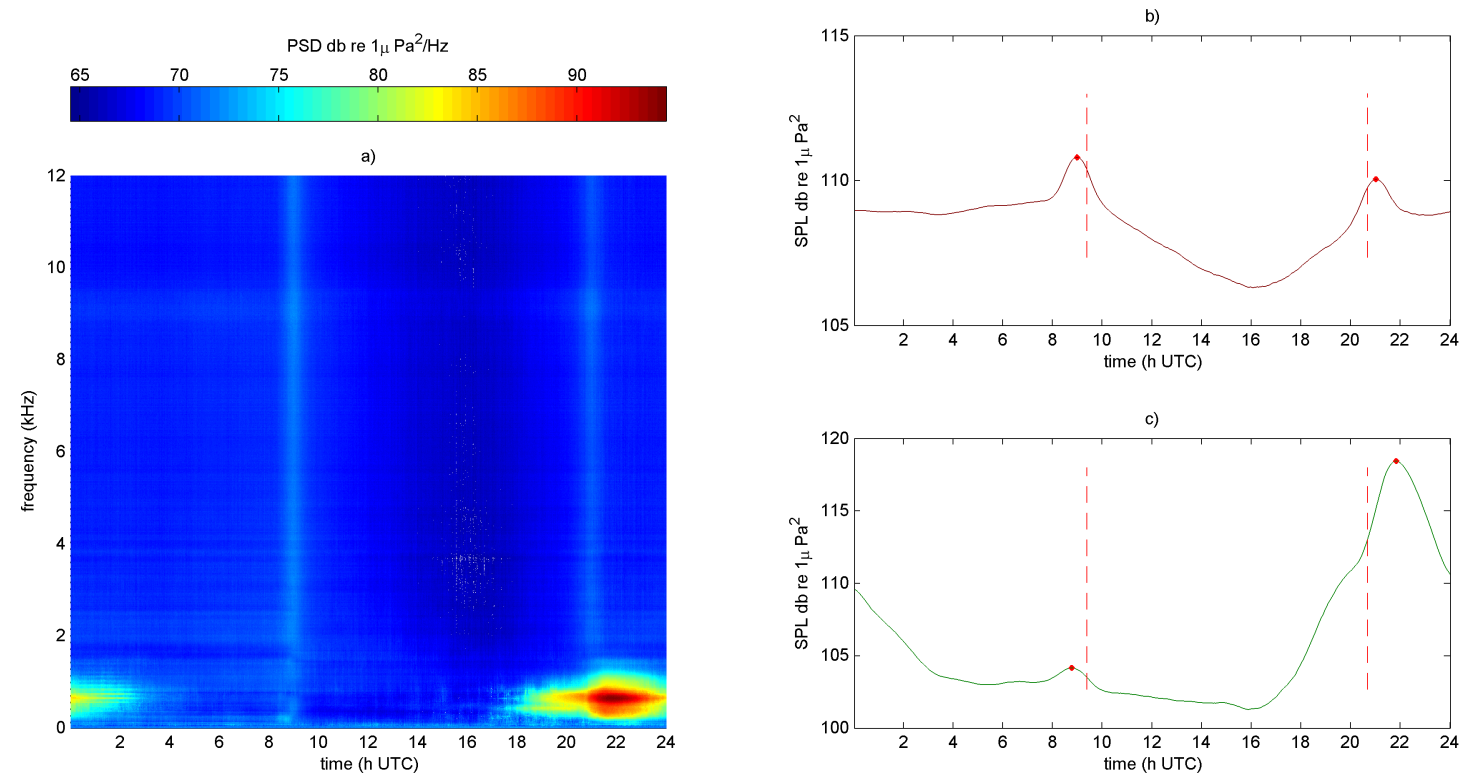

Figure 41 - Average soundscape summarization for April $7^{\text {th }}$ - May $7^{\text {th }}$; a) median 24 - h spectrogram, b) median 24-h Low-FB SPL, c) median 24-h High-FB SPL.

Temporal evolution of dawn and dusk chorus activities can be evaluated by the peaks detected in median 24-h SPL in frequency bands. Table 7 suggests that rises in acoustic activity at dawn and dusk follow the time variation of sunrise and sunset through the studied period. While sunrise is later from March to June, sunset is earlier, situation repeated for the respective peaks in the proximities of these 
reference points. This fact evinces a relation of chorus activities with sun position in daily and seasonal scales.
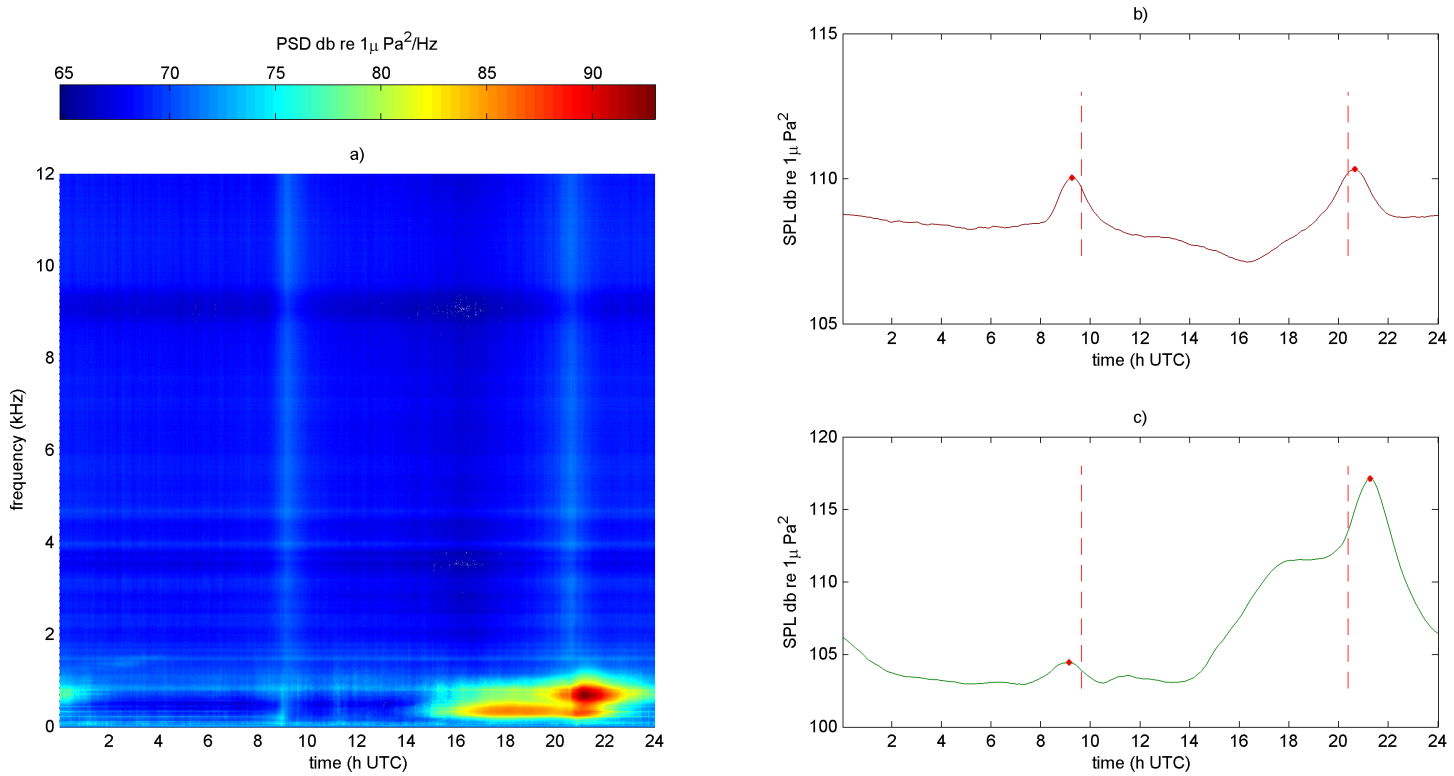

Figure 42 - Average soundscape summarization for May $8^{\text {th }}-$ June $7^{\text {th }}$; a) median 24 - h spectrogram, b) median 24-h Low-FB SPL, c) median 24-h High-FB SPL.

Table 7 - Time (h UTC) of highest peaks near sunrise $\left(P e a k_{s r}\right)$ and sunset $\left(P e a k_{s s}\right)$ in median average SPL by frequency bands. Denoted by red points in Figures 40, 41 and 42.

\begin{tabular}{|c|c|c|c|c|c|c|}
\hline \multirow{3}{*}{$\begin{array}{l}\text { Period } \\
7^{t h}-\operatorname{Apr} 6^{t h}\end{array}$} & \multirow[b]{2}{*}{ Mean sunrise } & \multirow[b]{2}{*}{ Mean sunset } & \multicolumn{2}{|c|}{$L o w-F B$} & \multicolumn{2}{|c|}{$H i g h-F B$} \\
\hline & & & $\mathrm{Peak}_{s r}$ & Peak & $\mathrm{Peak}_{s r}$ & Peak $_{s s}$ \\
\hline & $9: 11$ & 21:09 & $8: 36(-35)$ & $22: 15(+66)$ & $8: 52(-19)$ & $21: 25(+16)$ \\
\hline Apr $7^{t h}-$ May $7^{t h}$ & $9: 23$ & $20: 40$ & $8: 46(-37)$ & $21: 49(+69)$ & $8: 59(-24)$ & $21: 00(+20)$ \\
\hline May $8^{\text {th }}-\operatorname{Jun} 7^{\text {th }}$ & $9: 38$ & $20: 22$ & 9:08(-30) & $21: 15(+53)$ & $9: 15(-23)$ & $20: 38(+16)$ \\
\hline Mar $7^{\text {th }}-$ Jun $7^{\text {th }}$ & $9: 24$ & $20: 44$ & $8: 47(-37)$ & $21: 49(+65)$ & $9: 00(-24)$ & $21: 06(+22)$ \\
\hline
\end{tabular}

Table 7 also shows the time of peaks for the median average SPL by frequency bands for the entire recorded period. These values were used to define the search space for automatic detection of dawn and dusk chorus activities, as described in section 6.2.2.4.

In (TOWSEY et al., 2014b), authors selected three acoustic indexes and mapped each to primary colors, red, green and blue (RGB) respectively, forming what they named as false-color 24-h spectrogram. By averaging these false color spectrograms by monthly periods they construct monthly false-color average spectrograms, and stated that patterns of biological choruses can be summarized by this procedure. The present study illustrates that by just averaging monthly spectrograms, by means of the median, important information is also retained in temporal and spectral patterns of choruses. These results reinforce the idea previously proposed (SANCHEZ-GENDRIZ; PADOVESE, 2016) that averaging 24-h spectrogram is useful for summarizing soundscapes, and also indicates that averaging by means of the median is preferred over the mean, in order to avoid that outliers values dominate the average. 


\subsubsection{Detection of dawn and dusk chorus activities}

Figure 43 illustrates the agreement between the adjusted values of chorus detected "time indicator" (see section 6.2.2.4) and sunrise and sunset. For the High-FB, both methods have similar performance for the detection of dawn and dusk chorus activities. In High-FB, the spectrum is principally dominated by crustaceous sounds and the daily values of peaks suffer fewer perturbations from other sounds. In contrast, in Low-FB there is more variability in sounds, which implies more constraints for the methods. In this part of the spectrum, the MaxAT shows better performance to detect dawn and dusk chorus activities. LoMAX method selects as the chorus "timing indicator" the highest local maximum whitin the search space. Eventually, the highest local maximum may not be related to a real increase in chorus acoustic activity, but to another events, as for example the passage of a vessel.

As a consequence of results presented in Figure 43 and Table 8, the MaxAT method was selected over LoMax for the detection of dawn and dusk chorus activities. For the four possible detection cases illustrated in Figure 43, MaxAT method shows more variability for values detected near sunrise for Low-FB. Even though, in this case the detection of acoustic activity (probably related to part of broadband energy from crustaceous sounds) still shows a relation with sunrise, but probably the occurrence of sound events without a real relation with sun position could explain the higher variability.

The method of MaxAT could be a useful tool applied to automatic detection of temporal patterns of key acoustic components of soundscape (dawn and dusk chorus), resulting helpful for analyzing large acoustic datasets.
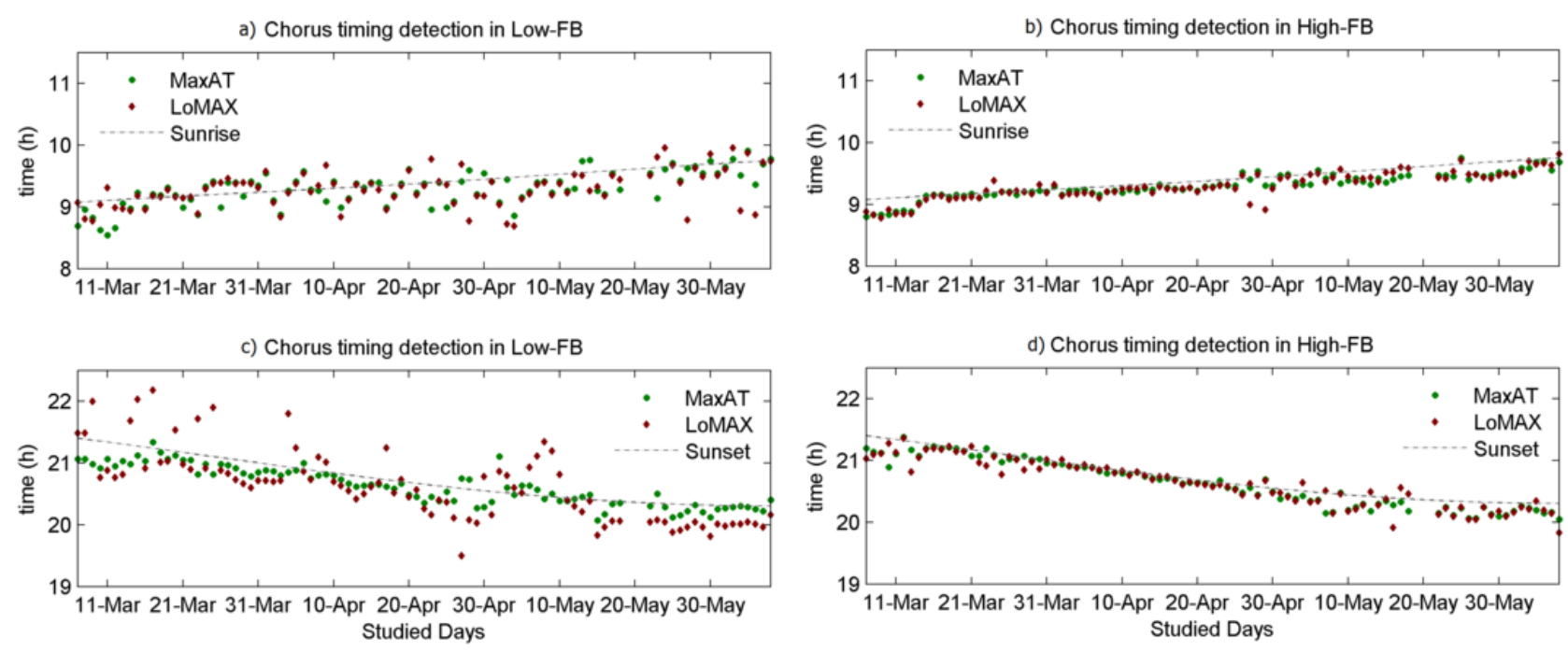

Figure 43 - Adjusted values of detected dawn and dusk chorus "timing" plotted over sunrise and sunset; a) dawn choruses detected in Low-FB, b) dawn choruses detected in High-FB, c) dusk choruses detected in Low-FB, b) dusk choruses detected in High -FB.

Table 8 - Standard deviation in minutes for detected values of chorus timing.

\begin{tabular}{ccccc}
\cline { 2 - 5 } & \multicolumn{2}{c}{ Low-FB } & \multicolumn{2}{c}{ High-FB } \\
\hline Methods & Sunrise & Sunset & Sunrise & Sunset \\
MaxAT & 11.6 & 9.4 & 4.0 & 4.6 \\
LoMAX & 15.6 & 23.0 & 5.9 & 7.2 \\
\hline
\end{tabular}




\subsubsection{SPL-gram image summarization}

From the Low-FB SPL and High-FB SPL time series represented in Figure 36, we see daily periodical peaks, one daily peak remarked in Low-FB and two in High-FB. Also, Figure 36 presents the unusual acoustic activity of vessel noise lasting for more than 2 days in total. The detection of dawn and dusk chorus activities implemented by MaxAT method and the monthly median average showed that trends in daily activity are strongly related to sunrise and sunset all over the studied period. In addition, the spectral information illustrated by median spectrograms allowed determining that, in Low-FB, the fonts seem to be related to fish shoals and, in High-FB, to crustacean sounds. An important part of this information is retained in SPL-gram image (Figure 44).
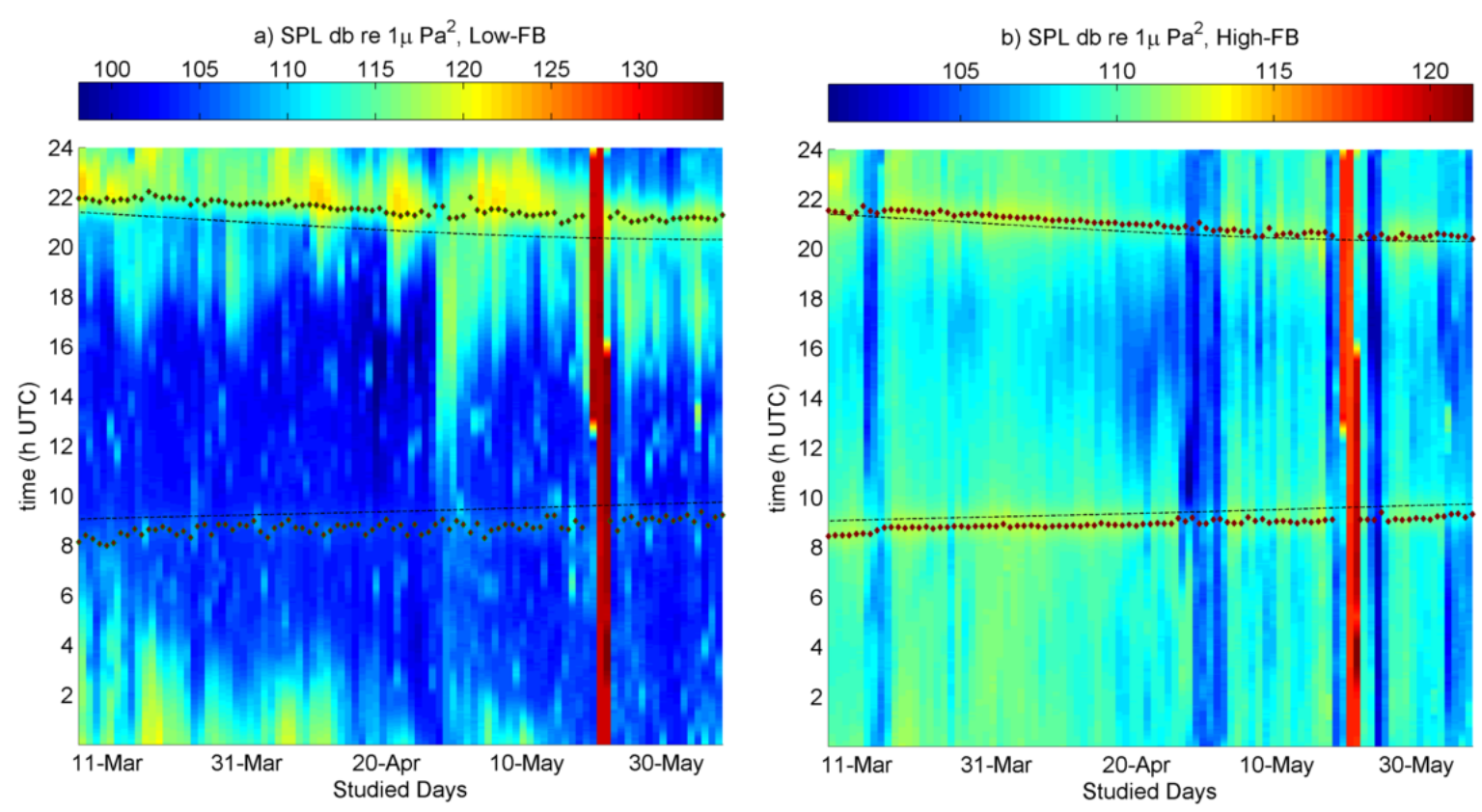

Figure 44 - SPL-gram images in the selected frequency bands. Traced lines represent sunrise and sunset and marker points indicate the dawn and dusk chorus activities detected by MaxAT method, a) Low-FB SPL-gram and b) High-FB SPL-gram.

For example, we can see the vessel noise, the dawn and dusk chorus activities and its relation to sun position through the season, and also how chorus duration shortens in early hours from March to June in Low-FB. In addition, Figure 44 reveals, by simple visual inspection, a correlation in the rise of SPL in the neighborhood of sunrise and sunset and the dawn and dusk chorus activities detected by MaxAT method.

The relation of daily periodical response of living creatures to sunlight is an omnipresent phenomenon in biological studies from years (ROENNEBERG; FOSTER, 1997). Adapting to the cyclical changes of the environment is vital for the survival of living organisms, which use the called biological or circadian clock for this purpose (BROWN, 2016; ROENNEBERG; FOSTER, 1997). The period of circadian clock, can be adjusted to the environment by several external cues. Sun light quality at dawn and dusk is recognized as an essential synchronizer of the circadian system in many organisms (BROWN, 2016; ROENNEBERG; FOSTER, 1997; ZHDANOVA; REEBS, 2005), triggering behavioral 
responses that are often associated to sound production. Consequently, the importance and usefulness of the methodos presented here.

The SPL-gram demonstrates its capacity to summarize and visualize large acoustic datasets in the form of a compact representation, obtained by means of a simple procedure. This visualization tool resulted successful in illustrating biological circadian rhythms detected in the monitored protected area. New acoustic data can be easily appended to previous SPL-gram, as described in section 6.2.2.3, daily curves of SPL in the selected frequency bands will be converted to a color-map bar, which will be added to the existing graph.

\subsection{Conclusions}

The present work addressed how traditional metrics of SPL, Spectrograms and its average can be used to develop innovative methods that can contribute to summarize and visualize large acoustic datasets. It is proposed a new graphic for soundscape representation, named here as SPL-gram, which is based on converting 24-h SPLs in selected frequency bands to color-map bars. Additionally, it is presented an algorithm for automatic detection of dawn and dusk chorus activities.

Monthly median average allowed summarizing the main spectral and temporal patterns of the monitored soundscape. Median average highlights daily periodical acoustic events synchronized with sunrise and sunset (the dawn and dusk choruses). In the Low-FB, these choruses appear to be originated by fish aggregations, similarly to those reported from another marine protected area close to the monitored one. In addition, in High-FB, the choruses seem to be related to crustacean noise. The timing of daily dawn and dusk choruses, in both frequency bands, were automatic detected by a method developed in this work, and visualized in respective SPL-Gram images. Especially, SPL-Gram revealed to be an effective visualization tool, being a compact and a simple extensible approach to summarize implicit information in large acoustic datasets.

The proposed methods highlighted circadian rhythms presented in the monitored environment, thus proving to be a valuable non-invasive tools that can reflect important ecological process for monitoring marine environments. Although the proposed methodos has used a unique long term underwater acoustic dataset as a case-study, it can be extended for monitoring other aquatic or terrestrial ecosystems, selecting suitable frequency bands for the particular cases.

Finally, it is worth nothing, that the monitored protected area is expected to be opened to public visits. Thus the described soundscape structure and the presented methodos represent a valuable baseline to evaluate the possible impacts from human activities in that pristine area. 


\title{
FIRST RECORDS OF HUMPBACK WHALE SOUNDS FROM SAO PAULO LONG-TERM PASSIVE ACOUSTIC MONITORING
}

\begin{abstract}
This study describes the detection of humpback whale sounds (HWS) for 13 days, from 102 days of underwater acoustic recordings at Alcatrazes Archipelago. The detection was performed inspecting 24-h spectrograms, followed by listening confirmation. The results constitute the first report of HWS obtained from long-term monitoring in Sao Paulo, Brazil.
\end{abstract}

Keywords: Bioacoustics, humpback whale, passive acoustic monitoring, spectrograms

Humpback whales (Megaptera novaeangliae) are migratory species that can be found in all oceans around the globe (HELWEG et al., 1998). In the summer, Humpback whales (HW) aggregate in high-latitude areas that are used for feeding (feeding areas), while in autumn they navigate to tropical waters, used for breeding (breeding areas) (HELWEG et al., 1998; RASMUSSEN et al., 2007). In the South Atlantic, when migrating from the Antarctic feeding area to the tropical breading area (mainly located in northeastern coast of Brazil), or vice versa, HW cross the subtropical waters of São Paulo state (ANDRIOLO et al., 2014; MOURA et al., 2013; SANTOS et al., 2010).

Visual detection, a common method used to monitor the presence or passage of HW involves the presence of human observers, and is quite ineffective when migration phenomenon takes place during the night or when the target remains out of the observer visual field.

On the other hand, passive acoustic monitoring (PAM) have proved to be a successful tool to monitor cetaceans (ZIMMER, 2011). Particularly PAM is commonly used to detect the presence of HW, since they are recognized to be one of the most sound producing whale species (DUNLOP et al., 2013).

Though there are reports of HW visual detection in Sao Paulo State shore waters, no long-term acoustic monitoring of HW was known for this migration passage area. The present work analyses an underwater acoustics dataset, collected at Alcatrazes Wildlife Refuge, located in the northern coast of Sao Paulo state (see Figure 28). The monitored period extends from June $17^{\text {th }}$ to October $7^{\text {th }}$, 2016; totalizing 102 days of continuous sound recordings. 
The system used for recording the underwater sounds, was the OceanPod 3.0. The acquisition settings were: $24 \mathrm{kHz}$ of sampling rate, 16 bit resolution and a system sensitivity of $-146.8 \mathrm{~dB}$ re $1 \mathrm{~V}$ $\mu \mathrm{Pa}^{-1}$. Data was continuously saved in 4 Secure Digital (SD) memory cards of $128 \mathrm{~GB}$ each, in wav files of 15 min duration, resulting in a volume of collected data of $420 \mathrm{~GB}$. In this case, the monitoring time was limited by the system battery pack power durability, and not by the available SD free space.

In order to analyze the whole collected dataset, 24-h spectrograms were constructed for each monitored day. These 24-h spectrograms were obtained by visualization of daily Pxx matrices. The procedure used to calculate daily Pxx matrices was explained previously in section 2.4. The Pxx matrices were computed, by means of the Welch method with 1-s Hamming window, 1025 frequency points, $50 \%$ of overlap, and with 60 -s temporal signal segments.

By inspecting the 24-h spectrograms, it was possible to recognize the days when HW have passed through the region in the vicinity of monitored points. Indeed, to validate that, audio files randomly selected within the time intervals with HW sounds were listened. The list of HW detection days is presented in Table 9, as well as the time intervals of HW sounds occurrence. As shown in Table 9, HW sounds were detected in 13 of the 102 days that comprehend the monitored period.

Table 9 - Days with HW sounds detected by spectrogram and listening inspection.

\begin{tabular}{ll}
\hline Days & Time of day with HW sounds \\
\hline July $1^{\text {st }}$ & $23 \mathrm{~h}-24 \mathrm{~h}$ \\
July $2^{\text {nd }}$ & $00 \mathrm{~h}-09 \mathrm{~h}, 11 \mathrm{~h}-12 \mathrm{~h}$ \\
July $3^{\text {rd }}$ & $00 \mathrm{~h}-12 \mathrm{~h}, 15 \mathrm{~h}-19 \mathrm{~h}$ \\
August $2^{\text {nd }}$ & $17 \mathrm{~h}-20 \mathrm{~h}$ \\
August $19^{\text {nd }}$ & $12 \mathrm{~h}-23 \mathrm{~h}$ \\
September $2^{\text {nd }}$ & $22 \mathrm{~h}-24 \mathrm{~h}$ \\
September $3^{\text {rd }}$ & $00 \mathrm{~h}-14 \mathrm{~h}$ \\
September $4^{\text {th }}$ & $00 \mathrm{~h}-06 \mathrm{~h}$ \\
September $7^{\text {th }}$ & $07 \mathrm{~h}-12 \mathrm{~h}$ \\
September $8^{\text {th }}$ & $00 \mathrm{~h}-03 \mathrm{~h}$ \\
September $10^{\text {th }}$ & $10 \mathrm{~h}-16 \mathrm{~h}, 20 \mathrm{~h}-23 \mathrm{~h}$ \\
September $12^{\text {th }}$ & $10 \mathrm{~h}-18 \mathrm{~h}$ \\
September $14^{\text {th }}$ & $12 \mathrm{~h}-24 \mathrm{~h}$ \\
\hline
\end{tabular}

Taking as an example, Figure 45 illustrates the 24-h spectrogram for July 2 nd , 2016. From this figure, HW sounds were detected between $00 \mathrm{~h}$ to $09 \mathrm{~h}$ approximately, and between $11 \mathrm{~h}$ and $12 \mathrm{~h}$. The mainly part of the acoustic energy emitted by HW in this case is below $1 \mathrm{KHz}$. Although part of the energy spreads also above this frequency range, this is less perceptible from Figure 45. A closer look in HW sound characteristics can be obtained from shorter spectrograms. Accordingly, Figure 46 represents 30 seconds of HW sounds detected in the audio file recorded at 7:28 in July $2^{\text {nd }}$.

Although not being the aim of the present study, it is worth nothing that other predominant sounds can be detected by 24-h spectrograms. For instance, in Figure 45, apart from HW sound, the lasting acoustic events appearing between $15 \mathrm{~h}$ and $22 \mathrm{~h}$ are originated by fish choruses, and are similar to other fish choruses previously reported from Laje de Santos Marine State Park (SANCHEZ-GENDRIZ; PADOVESE, 2016) another protected area nearby. 


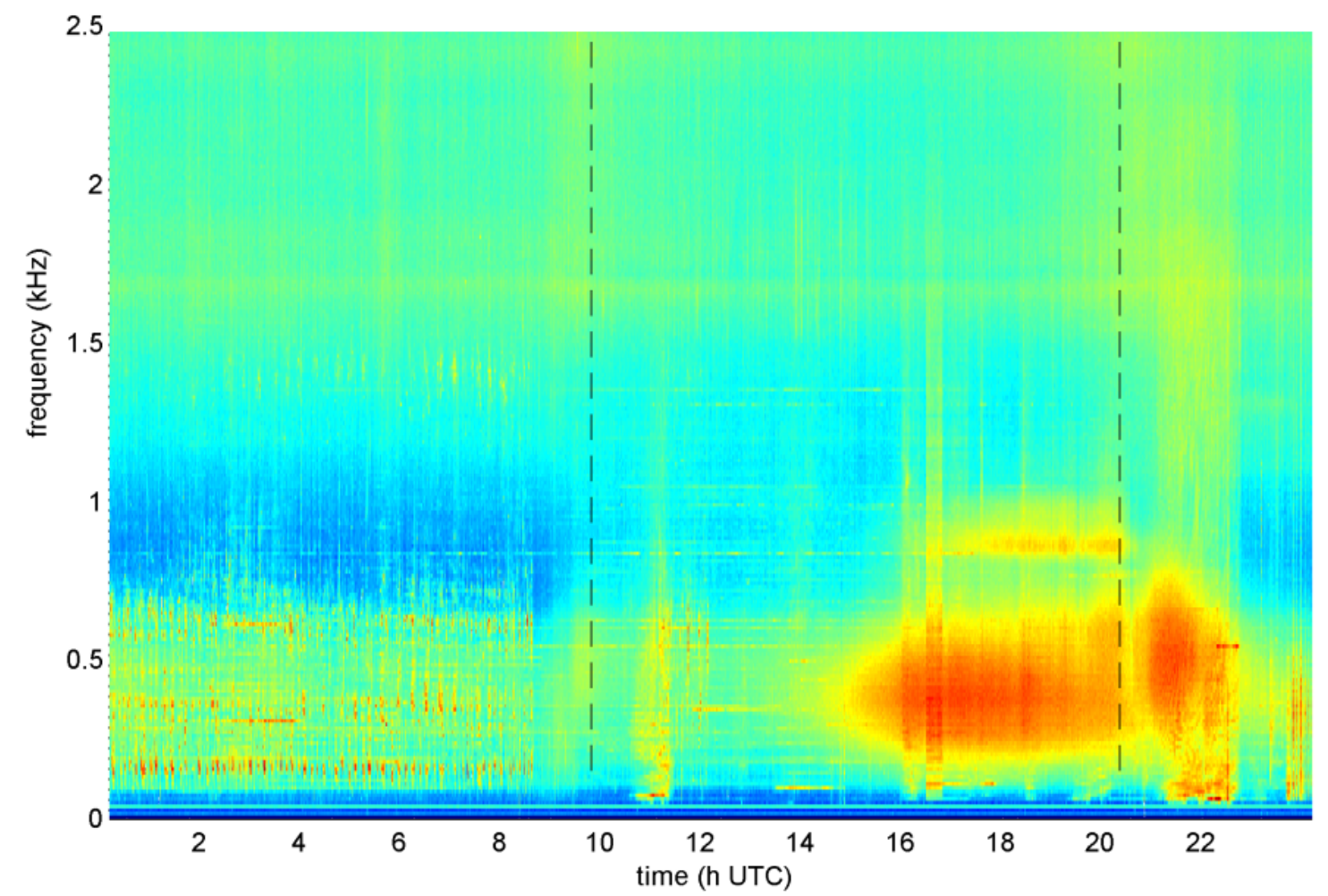

Figure 45 - 24-h spectrogram from July $2^{\text {nd }}$, 2016; the sunrise and sunset time occurrence are indicated by traced lines. Tow prominent biological sounds types can be highlighted below $1 \mathrm{kHz}$ : between $00 \mathrm{~h}-09 \mathrm{~h}$ and $11 \mathrm{~h}-12 \mathrm{~h}$ HW sounds, and between $15 \mathrm{~h}-22 \mathrm{~h}$ fish choruses.

The results here presented constitute the first reports of HW sounds detected from a long-term autonomous acoustic monitoring in Sao Paulo state coast. The computation of daily 24-h spectrograms proved to be a useful tool to assist in the detection of HW sounds. The inspection of 24-h spectrograms, followed by listening selected audio files, within specific time intervals highlighted by spectrogram images constitutes the proposed methodology. This procedure really reduces the effort of detecting HW sounds in

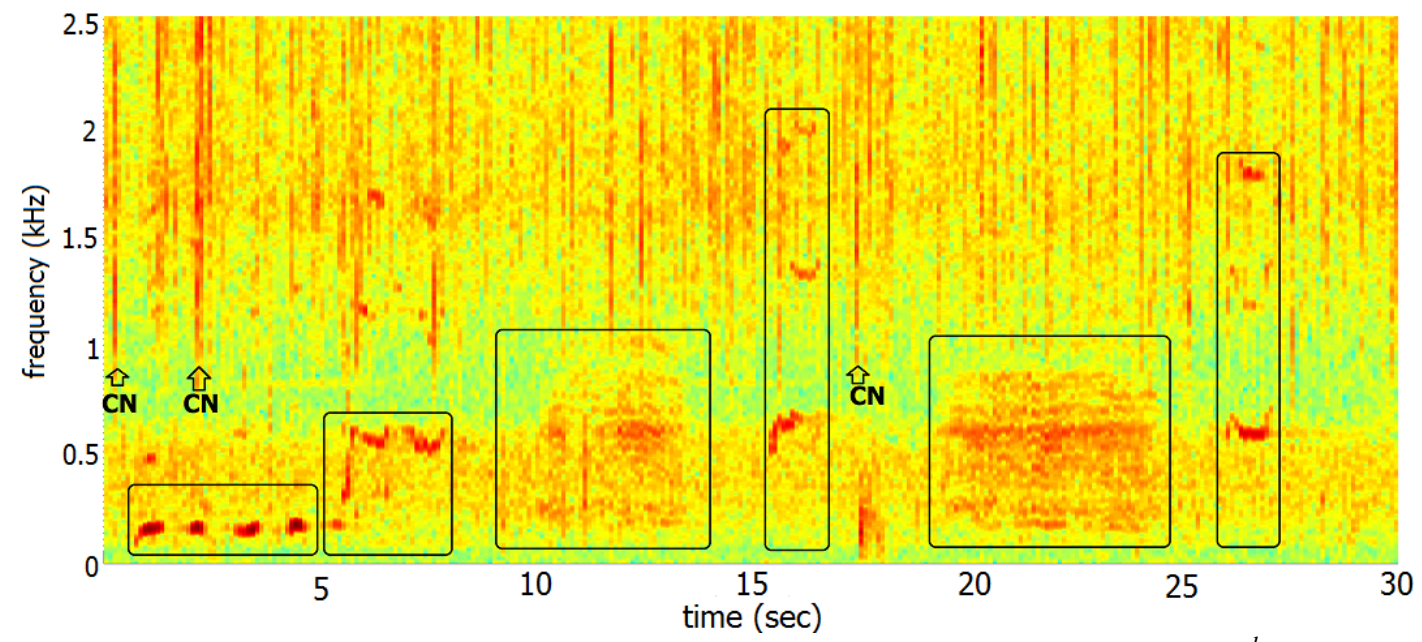

Figure 46 - Spectrogram of 30 seconds of underwater sounds recorded Alcatrazes on July $2^{\text {nd }}$. The demarcated rectangular areas contain HW sounds, Crustaceus biological Noise $(\mathrm{CN})$ examples are also annotated. 
long-term monitoring programs. Additionally, the presented methodology could be implemented in others marine reserves around Brazil for monitoring HW and soniferous species in general. 


\section{OVERALL CONCLUSIONS}

One can surely assert that measurements carried out through the development of the present research, represent now, the largest underwater acoustic data obtained in Brazilian seas. The monitored points included areas of great economic and environmental importance for the São Paulo State, that are:

- Ilha das Palmas, a point located at the entrance of the port of Santos channel, the biggest and busiest port in Latin America.

- Xixova-Japuí State Park, a protected park inside an area severely affected by environmental impacts, particularly unplanned urban settlement, industrialization and related port activities.

- Laje de Santos Marine State Park.

- Alcatrazes Wildlife Refuge.

The last two points constitute important areas for the preservation of marine life in São Paulo State.

In general terms, the current research represents the first-ever description of the monitored soundscapes. Indeed, the overall results establish a baseline for studing the underwater acoustic habitat of São Paulo coast. The qualitative and quantitative soundscape descriptions here presented can be used for comparisons with other regions in Brazil or around the world. Additionally, the work signifies a reference to investigate possible changes due to climatic variations and human activities in the monitored marine habitats; and reveals particularities of the studied environments.

- Explained by its proximity to the port of Santos, the Ilha das Palmas showed elevated SPL magnitude, which reachs values that can negatively impact some species like fish and marine mammals.

- Biological chorus, revealing daily periodical patterns strongly related to sunrise and sunset, dominated the soundscapes of the protected areas. The similarities of these biological sounds with those described in the specialized literature suggest that the sound sources are fish shoals and crustacean noise. 
- The species that produce the choruses were not identified in the present study, but this identification could constitute the aim of subsequent research projects.

- Nevertheless, the present research signifies the first attempt to catalog fish choruses in the Brazilian southwest coast, providing spectral features and temporal patterns of these key acoustic events.

In addition, the work evinced that traditional metrics of Power Spectral Density, SPL and Spectrograms can be used to develop innovative methods that can contribute to summarize and visualize large acoustic datasets. Power Spectral Density matrices were used as fundamental analysis blocks for implementing the calculations of remaing metrics. Once in frequency domain, the computation of SPL and Spectrograms, even in seleted frequency bands, is straightforward.

- 24-h spectrograms allowed determining the temporal and spectral characteristics of monitored soundscape at a daily scale. As a particular case, the 24-h spectrogram was effectively used for the detection of Humpback Whales sounds in 102 days of acoustic monitoring in São Paulo waters. Monthly average spectrogram permitted to summarize soundscape trends of the studied natural areas.

- Based on 24-h SPL curves, two new analysis tools were developed during this research: The Maximal Area Triangulation method (MaxAT) and a visualization tool named as SPL-Gram. The MaxAt method allow the automatic detection of dawn and dusk chorus activities. As case study, MaxAt highlighted circadians rhythms presented in collected data from Alcatrazes Wildlife Refuge. SPL-Gram revealed to be an effective visualization tool, being simple and easily reproducible approach, that can be used to summarize implicit information in large acoustic datasets.

- These results encourage the use 24h-Spectrograms and SPL curves, sice they are well-established and still valuable techniques that proved to be effective to explore large acoustic datasets.

Finally, the present research indicates to environmental Brazilian agencies, and to the related scientific community, that passive acoustic monitoring is a noninvasive and cost-effective tool that can be used for management of marine protected areas, as well as for areas of economical relevance. 
Amado Filho, G. M.; HORTA, P. a.; BRASILEIRO, P. S.; BARROS-BARRETO, M. B.; FUJII, M. T. Subtidal benthic marine algae of the Marine State Park of Laje de Santos (São Paulo, Brazil). Brazilian Journal of Oceanography, v. 54, n. 4, p. 225-234, dec 2006. ISSN 1679-8759. Disponível em: <http://www.scielo. br/scielo.php?script=sci $\left\{\_\right\}$arttext $\{\&\}$ pid=S1679-87592006000300006 $\{\&\} \operatorname{lng}=\mathrm{en}\{\&\} \mathrm{nrm}>$. Cited 3 times on pages 46,57 , and 58 .

ANDRIOLO, A.; ZERBINI, A. N.; MOREIRA, S.; PIZZORNO, J. L.; DANILEWICZ, D.; MAIA, Y. G.; MAMEDE, N.; CASTRO, F. R. de; CLAPHAM, P. What do humpback whales Megaptera novaeangliae (Cetartiodactyla: Balaenopteridae) pairs do after tagging? Zoologia (Curitiba), v. 31, n. 2, p. 105-113, apr 2014. ISSN 1984-4670. Disponível em: <http://www.scopus.com/inward/record.url?eid=2-s2.0-84901039976 \&\&\}partnerID=tZOtx3y1http: //www.scielo.br/scielo.php?script=sci $\left\{\_\right\} \operatorname{arttext}\{\&\}$ pid=S1984-46702014000200001 $\{\&\} \operatorname{lng}=e n\{\&\}>$. Cited on page 83.

ARAUJO, G. S.; MOREIRA, L. B.; MORAIS, R. D.; DAVANSO, M. B.; GARCIA, T. F.; CRUZ, a. C. F.; ABESSA, D. M. S. Ecotoxicological assessment of sediments from an urban marine protected area (Xixová-Japuí State Park, SP, Brazil). Marine Pollution Bulletin, Elsevier Ltd, v. 75, n. 1-2, p. 62-68, 2013. ISSN 0025326X. Disponível em: <http://dx.doi.org/10.1016/j.marpolbul.2013.08.005>. Cited 3 times on pages 46,57 , and 58 .

AU, W. W. L.; BANKS, K. The acoustics of the snapping shrimp. J. Acoust. Soc. Am, p. 41-47, 1998. Cited on page 54.

BITTENCOURT, L.; CARVALHO, R. R.; LAILSON-BRITO, J.; AZEVEDO, a. F. Underwater noise pollution in a coastal tropical environment. Marine Pollution Bulletin, Elsevier Ltd, v. 83, n. 1, p. 331336, 2014. ISSN 18793363. Disponível em: <http://dx.doi.org/10.1016/j.marpolbul.2014.04.026>. Cited on page 46.

BOHNENSTIEHL, D. R.; LILLIS, A.; EGGLESTON, D. B. The curious acoustic behavior of estuarine snapping shrimp: temporal patterns of snapping shrimp sound in sub-tidal oyster reef habitat. PloS one, Public Library of Science, v. 11, n. 1, p. e0143691, 2016. Cited 2 times on pages 72 and 77.

BROWN, T. M. Using light to tell the time of day: sensory coding in the mammalian circadian visual network. The Journal of Experimental Biology, v. 219, n. 12, p. 1779-1792, jun 2016. ISSN 0022-0949. Disponível em: <http://jeb.biologists.org/lookup/doi/10.1242/jeb.132167>. Cited on page 81.

BUSCAINO, G.; CERAULO, M.; PIERETTI, N.; CORRIAS, V.; FARINA, A.; FILICIOTTO, F.; MACCARRONE, V.; GRAMMAUTA, R.; CARUSO, F.; GIUSEPPE, A. et al. Temporal patterns in the soundscape of the shallow waters of a mediterranean marine protected area. Scientific Reports, Nature Publishing Group, v. 6, 2016. Cited 5 times on pages 58, 70, 72, 73, and 75.

CALDAS-MORGAN, M.; ALVAREZ-ROSARIO, A.; PADOVESE, L. R. An Autonomous Underwater Recorder Based on a Single Board Computer. PLOS ONE, v. 10, n. 6, p. e0130297, jun 2015. ISSN 1932-6203. Disponível em: <http://dx.plos.org/10.1371/journal.pone.0130297>. Cited on page 47.

CATO, D. H. Marine biological choruses observed in tropical waters near australia. The Journal of the Acoustical Society of America, ASA, v. 64, n. 3, p. 736-743, 1978. Cited on page 52. 
CODARIN, A.; WYSOCKI, L. E.; LADICH, F.; PICCIULIN, M. Effects of ambient and boat noise on hearing and communication in three fish species living in a marine protected area (Miramare, Italy). Marine Pollution Bulletin, v. 58, n. 12, p. 1880-1887, dec 2009. ISSN 0025326X. Disponível em: $<$ http://linkinghub.elsevier.com/retrieve/pii/S0025326X09003075>. Cited on page 38.

COQUEREAU, L.; GRALL, J.; CHAUVAUD, L.; GERVAISE, C.; CLAVIER, J.; JOLIVET, A.; Di Iorio, L. Sound production and associated behaviours of benthic invertebrates from a coastal habitat in the north-east Atlantic. Marine Biology, Springer Berlin Heidelberg, v. 163, n. 5, p. 127, may 2016. ISSN 0025-3162. Disponível em: <http://link.springer.com/10.1007/s00227-016-2902-2>. Cited 3 times on pages 48,72 , and 77 .

CORDEIRO, A. S.; LUQUE, J. L. Community ecology of the metazoan parasites of Atlantic Moonfish, Selene setapinnis (Osteichthyes: Carangidae) from the coastal zone of the state of Rio de Janeiro, Brazil. Brazilian Journal of Biology, v. 64, n. 3a, p. 399-406, aug 2004. ISSN 1519-6984. Disponível em: $<$ http://www.scielo.br/scielo.php?script=sci $\left\{\backslash_{-}\right\} \operatorname{arttext}\{\&\}$ pid=S1519-69842004000300004 $\{\&\} 1 \mathrm{ng}=$ en $\{\&\} \mathrm{nrm}>$. Cited on page 51 .

DECOURSEY, W. Statistics and Probability for Engineering Applications. [s.n.], 2003. ISSN 0971-8044. ISBN 9780750676182. Disponível em: < http://www.sciencedirect.com/science/article/pii/ B9780750676182500172>. Cited 2 times on pages 32 and 62.

DUNLOP, R. a.; NOAD, M. J.; CATO, D. H.; KNIEST, E.; MILLER, P. J. O.; SMITH, J. N.; STOKES, M. D. Multivariate analysis of behavioural response experiments in humpback whales (Megaptera novaeangliae). Journal of Experimental Biology, v. 216, n. 5, p. 759-770, 2013. ISSN 0022-0949. Disponível em: <http://jeb.biologists.org/cgi/doi/10.1242/jeb.071498>. Cited on page 83.

ELDRIDGE, A.; CASEY, M.; MOSCOSO, P.; PECK, M. A new method for ecoacoustics? Toward the extraction and evaluation of ecologically-meaningful soundscape components using sparse coding methods. PeerJ, v. 4, p. e2108, jun 2016. ISSN 2167-8359. Disponível em: <https://peerj.com/preprints/ 1407.pdfhttps://peerj.com/articles/2108>. Cited 2 times on pages 25 and 70.

ERBE, C. Underwater Acoustics: Noise and the Effects on Marine Mammals. A Pocket Handbook. [S.1.: s.n.], 2011. Cited on page 30.

ERBE, C.; VERMA, A.; MCCAULEY, R.; GAVRILOV, A.; PARNUM, I. The marine soundscape of the perth canyon. Progress in Oceanography, Elsevier, v. 137, p. 38-51, 2015. Cited 3 times on pages 58, 69 , and 70 .

FARINA, A.; JAMES, P. The acoustic communities: Definition, description and ecological role. Biosystems, Elsevier Ireland Ltd, v. 147, p. 11-20, sep 2016. ISSN 03032647. Disponível em: <http://dx.doi.org/10.1016/j.biosystems.2016.05.011http://linkinghub.elsevier.com/ retrieve/pii/S0303264716300740>. Cited 3 times on pages 69, 70, and 73 .

GAGE, S. H.; AXEL, A. C. Visualization of temporal change in soundscape power of a Michigan lake habitat over a 4-year period. Ecological Informatics, Elsevier B.V., v. 21, p. 100-109, may 2014. ISSN 15749541. Disponível em: <http://dx.doi.org/10.1016/j.ecoinf.2013.11.004http://linkinghub.elsevier.com/ retrieve/pii/S1574954113001179>. Cited 2 times on pages 25 and 70.

GARRETT, J.; BLONDEL, P.; GODLEY, B.; PIKESLEY, S.; WITT, M.; JOHANNING, L. Long-term underwater sound measurements in the shipping noise indicator bands $63 \mathrm{~Hz}$ and $125 \mathrm{~Hz}$ from the port of Falmouth Bay, UK. Marine Pollution Bulletin, v. 110, n. 1, p. 438-448, sep 2016. ISSN 0025326X. Disponível em: <http://linkinghub.elsevier.com/retrieve/pii/S0025326X16304258>. Cited on page 42.

GOBBATO, G. M. Evaluation of metals and hydrocarbons gradiente on the sediments from Santos and São Vicente estuary system to Marine State Park of Laje de Santos. Tese (MSc.) - 
University of São Paulo, 2012. Disponível em: <http://www.teses.usp.br/teses/disponiveis/85/85134/ tde-15042013-103922/publico/2012GobbatoAvaliacao.pdf>. Cited on page 46.

GONÇALVES, L. R.; ANDRIOLO, A. Ocorrência, distribuição e comportamento de baleias-de-bryde (balaenoptera edeni anderson, 1879)(cetacea, mysticeti) em áreas costais e oceânicas do sudeste do brasil. Revista Brasileira de Zoociências, v. 8, n. 2, 2009. Cited 2 times on pages 36 and 57.

GONÇALVES, L. R.; AUGUSTOWSKI, M.; ANDRIOLO, A. Occurrence, distribution and behaviour of bryde's whales (cetacea: Mysticeti) off south-east brazil. Journal of the Marine Biological Association of the United Kingdom, Cambridge Univ Press, v. 96, n. 04, p. 943-954, 2016. Cited 2 times on pages 36 and 57.

GÖTZ, T.; HASTIE, G.; HATCH, L. T.; RAUSTEIN, O.; SOUTHALL, B. L.; TASKER, M.; THOMSEN, F.; CAMPBELL, J.; FREDHEIM, B. Overview of the impacts of anthropogenic underwater sound in the marine environment. OSPAR Biodiversity Series, v. 441, 2009. Cited 5 times on pages 15, 36, 39, 42, and 45.

HARRIS, S. A.; SHEARS, N. T.; RADFORD, C. A. Ecoacoustic indices as proxies for biodiversity on temperate reefs. Methods in Ecology and Evolution, v. 7, n. 6, p. 713-724, jun 2016. ISSN 2041210X. Disponível em: <http://doi.wiley.com/10.1111/2041-210X.12527>. Cited 2 times on pages 31 and 70.

HATCH, L.; CLARK, C.; MERRICK, R.; Van Parijs, S.; PONIRAKIS, D.; SCHWEHR, K.; THOMPSON, M.; WILEY, D. Characterizing the relative contributions of large vessels to total ocean noise fields: a case study using the Gerry E. Studds Stellwagen Bank National Marine Sanctuary. Environmental management, v. 42, n. 5, p. 735-52, nov 2008. ISSN 0364-152X. Disponível em: <http://www.ncbi.nlm. nih.gov/pubmed/18626686>. Cited on page 38 .

HELWEG, D. a.; CATO, D. H.; JENKINS, P. F.; GARRIGUE, C.; ROBERT, D. Geographic Variation in South Pacific Humpback Whale Songs. Behaviour, v. 135, n. 1, p. 1-27, 1998. Cited on page 83.

HILDEBRAND, J. a. Anthropogenic and natural sources of ambient noise in the ocean. Marine Ecology Progress Series, v. 395, p. 5-20, 2009. ISSN 01718630. Cited on page 42.

HOFF, N. T.; FIGUEIRA, R. C.; ABESSA, D. M. Levels of metals, arsenic and phosphorus in sediments from two sectors of a brazilian marine protected area (tupinambás ecological station). Marine pollution bulletin, Elsevier, v. 91, n. 2, p. 403-409, 2015. Cited on page 70.

JAMES, G.; WITTEN, D.; HASTIE, T.; TIBSHIRANI, R. An Introduction to Statistical Learning. New York, NY: Springer New York, 2013. v. 103. 431 p. (Springer Texts in Statistics, v. 103). ISSN 01621459. ISBN 978-1-4614-7137-0. Disponível em: <http://link.springer.com/10.1007/978-1-4614-7138-7>. Cited on page 67.

JOO, W.; NAPOLETANO, B.; QI, J.; GAGE, S.; BISWAS, S. Soundscape characteristics of an environment a new ecological indicator of ecosystem health. In: JI, W. (Ed.). Wetland and Water Resource Modeling and Assessment. Crc press. New York, USA: [s.n.], 2007. cap. 17, p. 201-211. Disponível em: <http://www.crcnetbase.com/doi/abs/10.1201/9781420064155.ch17>. Cited on page 70.

JORDÃO, J. M.; FONSECA, P. J.; AMORIM, M. C. P. Chorusing Behaviour in the Lusitanian Toadfish: Should I Match My Neighbours' Calling Rate? Ethology, v. 118, n. 9, p. 885-895, sep 2012. ISSN 01791613. Disponível em: <http://doi.wiley.com/10.1111/j.1439-0310.2012.02078.x>. Cited 4 times on pages $48,65,66$, and 72 .

JORGE, R. R.; HARARI, J.; FUJII, M. T. Macroalgal composition and its association with local hydrodynamics in the Laje de Santos Marine State Park, Southwestern Atlantic, São Paulo, Brazil. Brazilian Journal of Oceanography, v. 60, n. 3, p. 405-419, 2012. ISSN 16798759. Cited 2 times on pages 46 and 57. 
LECHNER, W.; WYSOCKI, L.; LADICH, F. Ontogenetic development of auditory sensitivity and sound production in the squeaker catfish Synodontis schoutedeni. BMC Biology, v. 8, n. 1, p. 10, 2010. ISSN 1741-7007. Disponível em: <http://www.biomedcentral.com/1741-7007/8/10>. Cited 2 times on pages 66 and 67.

LOCASCIO, J. V.; BURTON, M. L. A passive acoustic survey of fish sound production at Riley's Hump within Tortugas South Ecological Reserve; implications regarding spawning and habitat use. Fishery Bulletin, v. 114, n. 1, p. 103-116, jan 2016. ISSN 00900656. Disponível em: <http://fishbull.noaa.gov/ 1141/locascio.pdf>. Cited 2 times on pages 53 and 59.

LOCASCIO, J. V.; MANN, D. A. Effects of hurricane charley on fish chorusing. Biology letters, The Royal Society, v. 1, n. 3, p. 362-365, 2005. Cited 4 times on pages 16, 51, 52, and 59.

. Diel periodicity of fish sound production in charlotte harbor, florida. Transactions of the American Fisheries Society, Taylor \& Francis Group, v. 137, n. 2, p. 606-615, 2008. Cited 4 times on pages 51, 52,59 , and 66.

. Diel and seasonal timing of sound production by black drum (Pogonias cromis). Fishery Bulletin, v. 109, n. 3, p. 327-338, 2011. ISSN 00900656. Cited 4 times on pages 65, 66, 67, and 70.

LUCZKOVICH, J. J.; MANN, D. a.; ROUNTREE, R. a. Passive Acoustics as a Tool in Fisheries Science. Transactions of the American Fisheries Society, v. 137, n. 2, p. 533-541, 2008. ISSN 0002-8487. Cited on page 66.

LUCZKOVICH, J. J.; PULLINGER, R. C.; JOHNSON, S. E.; SPRAGUE, M. W. Identifying Sciaenid Critical Spawning Habitats by the Use of Passive Acoustics. Transactions of the American Fisheries Society, v. 137, n. 2, p. 576-605, feb 2008. ISSN 0002-8487. Disponível em: <http://www.tandfonline. com/doi/abs/10.1577/T05-290.1>. Cited 3 times on pages 51, 52, and 66.

LUIZ, O. J.; CARVALHO-FILHO, A.; FERREIRA, C. E. L.; FLOETER, S. R.; GASPARINI, J. L.; SAZIMA, I. The reef fish assemblage of the Laje de Santos Marine State Park, Southwestern Atlantic: Annotated checklist with comments on abundance, distribution, trophic structure, symbiotic associations, and conservation. Zootaxa, n. 1807, p. 1-25, 2008. ISSN 11755326. Cited 2 times on pages 46 and 57.

MALFANTE, M.; Dalla Mura, M.; MARS, J. I.; GERVAISE, C. Automatic fish sounds classification. The Journal of the Acoustical Society of America, v. 139, n. 4, p. 2115-2116, apr 2016. ISSN 0001-4966. Disponível em: <http://asa.scitation.org/doi/10.1121/1.4950295>. Cited on page 67.

MANN, D.; GROTHUES, T. Short-term upwelling events modulate fish sound production at a midAtlantic Ocean observatory. Marine Ecology Progress Series, v. 375, p. 65-71, jan 2009. ISSN 01718630. Disponível em: <http://www.int-res.com/abstracts/meps/v375/p65-71/>. Cited 3 times on pages 15,51 , and 52.

MARQUES, P. A. M.; MAGALHÃES, D. M.; PEREIRA, S. F.; JORGE, P. E. From the Past to the Future: Natural Sound Recordings and the Preservation of the Bioacoustics Legacy in Portugal. PLoS ONE, v. 9, n. 12, p. e114303, dec 2014. ISSN 1932-6203. Disponível em: <http://dx.plos.org/10.1371/journal.pone. $0114303>$. Cited on page 25.

MCCAULEY, R. D. Fish choruses from the Kimberley, seasonal and lunar links as determined by long term sea noise monitoring. Proceedings of the Acoustical Society of Australia;, n. November, p. 21-23 November, 2012. Cited 5 times on pages 52, 60, 64, 66, and 67.

MCCAULEY, R. D.; CATO, D. H. Patterns of fish calling in a nearshore environment in the Great Barrier Reef. Philosophical Transactions of the Royal Society B: Biological Sciences, v. 355, n. 1401, p. 1289-1293, sep 2000. ISSN 0962-8436. Disponível em: <http://rstb.royalsocietypublishing.org/cgi/doi/ 10.1098/rstb.2000.0686>. Cited 4 times on pages 64, 66, 67, and 75. 
MCKENNA, M. F.; ROSS, D.; WIGGINS, S. M.; HILDEBRAND, J. a. Underwater radiated noise from modern commercial ships. The Journal of the Acoustical Society of America, v. 131, n. 1, p. 92, 2012. ISSN 00014966 . Cited 3 times on pages 36, 38, and 42.

MCWILLIAM, J. N.; HAWKINS, A. D. A comparison of inshore marine soundscapes. Journal of Experimental Marine Biology and Ecology, Elsevier, v. 446, p. 166-176, 2013. Cited on page 58.

MERCHANT, N. D.; BLONDEL, P.; DAKIN, D. T.; DOROCICZ, J. Averaging underwater noise levels for environmental assessment of shipping. The Journal of the Acoustical Society of America, v. 132, n. 4, p. EL343-9, oct 2012. ISSN 1520-8524. Disponível em: <http://www.ncbi.nlm.nih.gov/pubmed/23039575>. Cited on page 76.

MERCHANT, N. D.; FRISTRUP, K. M.; JOHNSON, M. P.; TYACK, P. L.; WITT, M. J.; BLONDEL, P.; PARKS, S. E. Measuring acoustic habitats. Methods in Ecology and Evolution, v. 6, n. 3, p. 257-265, mar 2015. ISSN 2041210X. Disponível em: <http://doi.wiley.com/10.1111/2041-210X.12330>. Cited 3 times on pages 31,45 , and 58 .

MERCHANT, N. D.; PIROTTA, E.; BARTON, T. R.; THOMPSON, P. M. Monitoring ship noise to assess the impact of coastal developments on marine mammals. Marine Pollution Bulletin, Elsevier Ltd, v. 78, n. 1-2, p. 85-95, 2014. ISSN 0025326X. Disponível em: <http://dx.doi.org/10.1016/j.marpolbul.2013.10. 058>. Cited 2 times on pages 48 and 72 .

MERCHANT, N. D.; WITT, M. J.; BLONDEL, P.; GODLEY, B. J.; SMITH, G. H. Assessing sound exposure from shipping in coastal waters using a single hydrophone and Automatic Identification System (AIS) data. Marine pollution bulletin, Elsevier Ltd, v. 64, n. 7, p. 1320-9, jul 2012. ISSN 1879-3363. Disponível em: <http://www.ncbi.nlm.nih.gov/pubmed/22658576>. Cited 6 times on pages 30, 31, 36, 38,39 , and 42 .

MONTIE, E. W.; VEGA, S.; POWELL, M. Seasonal and Spatial Patterns of Fish Sound Production in the May River, South Carolina. Transactions of the American Fisheries Society, v. 144, n. 4, p. 705-716, jul 2015. ISSN 0002-8487. Disponível em: <http://www.tandfonline.com/doi/full/10.1080/00028487. 2015.1037014>. Cited 2 times on pages 66 and 67.

MOONEY, T.; KAPLAN, M.; IZZI, A.; LAMONI, L.; SAYIGH, L. Temporal trends in cusk eel sound production at a proposed US wind farm site. Aquatic Biology, v. 24, n. 3, p. 201-210, feb 2016. ISSN 1864-7782. Disponível em: <http://www.int-res.com/abstracts/ab/v24/n3/p201-210/>. Cited on page 67.

MOURA, J.; RODRIGUES, D.; ROGES, E.; SOUZA, R.; OTT, P.; TAVARES, M.; LEMOS, L.; TAVARES, D.; SICILIANO, S. Humpback whales washed ashore in southeastern Brazil from 1981 to 2011: stranding patterns and microbial pathogens survey. Biologia, v. 68, n. 5, p. 992-999, jan 2013. ISSN 1336-9563. Disponível em: <http://link.springer.com/10.2478/s11756-013-0237-8http://www.degruyter.com/view/ j/biolog.2013.68.issue-5/s11756-013-0237-8/s11756-013-0237-8.xml>. Cited on page 83.

OPPENHEIM, A.; SCHAFER, R. Dsp history - From frequency to quefrency: a history of the cepstrum. IEEE Signal Processing Magazine, v. 21, n. 5, p. 95-106, sep 2004. ISSN 1053-5888. Disponível em: $<$ http://ieeexplore.ieee.org/lpdocs/epic03/wrapper.htm?arnumber=1328092>. Cited on page 61.

PARSONS, M. J. G.; MCCAULEY, R. D.; MACKIE, M. C. Characterisation of mulloway Argyrosomus japonicus advertisement sounds. Acoustics Australia, v. 41, n. 3, p. 196-201, 2013. ISSN 08146039. Cited 4 times on pages 51, 52, 53, and 60 .

PARSONS, M. J. G.; SALGADO-KENT, C. P.; MARLEY, S. A.; GAVRILOV, A. N.; MCCAULEY, R. D. Characterizing diversity and variation in fish choruses in Darwin Harbour. ICES Journal of Marine Science: Journal du Conseil, v. 73, n. 8, p. 2058-2074, sep 2016. ISSN 1054-3139. Disponível em: $<$ http://icesjms.oxfordjournals.org/lookup/doi/10.1093/icesjms/fsw037>. Cited 10 times on pages 16, 48, $60,61,64,66,67,72,73$, and 75 . 
PARSONS, M. J. G.; Salgado Kent, C. P.; RECALDE-SALAS, A.; MCCAULEY, R. D. Fish choruses off Port Hedland, Western Australia. Bioacoustics, Taylor \& Francis, v. 4622, n. September, p. 1-18, sep 2016. ISSN 0952-4622. Disponível em: <https://www.tandfonline.com/doi/full/10.1080/09524622.2016. 1227940>. Cited 6 times on pages 48, 53, 60, 66, 67, and 72 .

PIERETTI, N.; DUARTE, M.; SOUSA-LIMA, R.; RODRIGUES, M.; YOUNG, R.; FARINA, A. Determining temporal sampling schemes for passive acoustic studies in different tropical ecosystems. Tropical Conservation Science, SAGE Publications Sage CA: Los Angeles, CA, v. 8, n. 1, p. 215-234, 2015. Cited on page 25 .

PIJANOWSKI, B. C.; FARINA, A.; GAGE, S. H.; DUMYAHN, S. L.; KRAUSE, B. L. What is soundscape ecology? An introduction and overview of an emerging new science. Landscape Ecology, v. 26, n. 9, p. 1213-1232, nov 2011. ISSN 0921-2973. Disponível em: <http://link.springer.com/10.1007/ s10980-011-9600-8>. Cited 2 times on pages 25 and 69.

PIJANOWSKI, B. C.; VILLANUEVA-RIVERA, L. J.; DUMYAHN, S. L.; FARINA, A.; KRAUSE, B. L.; NAPOLETANO, B. M.; GAGE, S. H.; PIERETTI, N. Soundscape Ecology: The Science of Sound in the Landscape. BioScience, v. 61, n. 3, p. 203-216, mar 2011. ISSN 00063568. Disponível em: <http://bioscience.oxfordjournals.org/cgi/doi/10.1525/bio.2011.61.3.6https://academic. oup.com/bioscience/article-lookup/doi/10.1525/bio.2011.61.3.6>. Cited 4 times on pages 25, 58, 69, and 70.

PROAKIS, J. G.; MANOLAKIS, D. K. Digital signal processing: principles, algorithms, and applications. 4th. ed. [S.1.: s.n.], 2007. Cited 4 times on pages 31, 32, 48, and 71.

RADFORD, C. a.; JEFFS, A. G.; TINDLE, C. T.; MONTGOMERY, J. C. Temporal patterns in ambient noise of biological origin from a shallow water temperate reef. Oecologia, v. 156, n. 4, p. 921-9, jul 2008. ISSN 0029-8549. Disponível em: <http://www.ncbi.nlm.nih.gov/pubmed/18461369>. Cited 2 times on pages 52 and 75 .

RASMUSSEN, K.; PALACIOS, D. M.; CALAMBOKIDIS, J.; SABORÍO, M. T.; Dalla Rosa, L.; SECCHI, E. R.; STEIGER, G. H.; ALLEN, J. M.; STONE, G. S. Southern Hemisphere humpback whales wintering off Central America: insights from water temperature into the longest mammalian migration. Biology Letters, v. 3, n. 3, p. 302-305, jun 2007. ISSN 1744-9561. Disponível em: <http://rsbl.royalsocietypublishing. org/content/3/3/302.shorthttp://rsbl.royalsocietypublishing.org/cgi/doi/10.1098/rsbl.2007.0067>. Cited on page 83 .

ROBINSON, S.; LEPPER, P.; HAZELWOOD, R. Good Practice Guide for Underwater Noise Measurement. [S.1.], 2014. 97 pp p. Cited 3 times on pages 31, 41, and 72.

ROCHA-CAMPOS, C.; MARINI-FILHO, O. J.; ENGEL, M. Brazil: Progress report on cetacean research, march 2006 to february 2007, with statistical data for the calendar year 2006 or season 2006/2007. International Whaling Commission, Cambridge, UK, 2007. Cited 3 times on pages 36, 46, and 57.

ROCHA, L. H.; FERREIRA, L. S.; PAULA, B. C.; RODRIGUES, F. H.; SOUSA-LIMA, R. S. An evaluation of manual and automated methods for detecting sounds of maned wolves ( Chrysocyon brachyurus Illiger 1815). Bioacoustics, v. 24, n. 2, p. 185-198, may 2015. ISSN 0952-4622. Disponível em: <http://www.tandfonline.com/doi/full/10.1080/09524622.2015.1019361>. Cited on page 67.

ROENNEBERG, T.; FOSTER, R. G. Twilight Times: Light and the Circadian System. Photochemistry and Photobiology, v. 66, n. 5, p. 549-561, nov 1997. ISSN 0031-8655. Disponível em: <http://doi.wiley. com/10.1111/j.1751-1097.1997.tb03188.x>. Cited on page 81.

ROUNTREE, R. A.; GILMORE, R. G.; GOUDEY, C. A.; HAWKINS, A. D.; LUCZKOVICH, J. J.; MANN, D. A. Listening to fish: applications of passive acoustics to fisheries science. Fisheries, Taylor \& Francis, v. 31, n. 9, p. 433-446, 2006. Cited 6 times on pages 45, 51, 52, 53, 65, and 66. 
SANCHEZ-GENDRIZ, I.; PADOVESE, L. R. Harbor sound level estimation for assessment of underwater ship noise. In: 2014 Oceans - St. John's. IEEE, 2014. p. 1-5. ISBN 978-1-4799-4918-2. Disponível em: <http://ieeexplore.ieee.org/lpdocs/epic03/wrapper.htm?arnumber=7003113http://ieeexplore.ieee.org/ document/7003113/>. Cited 2 times on pages 26 and 46.

. Underwater sound pressure levels in the Port of Santos: Representative sample of forty-five days. In: 2015 IEEE/OES Acoustics in Underwater Geosciences Symposium (RIO Acoustics). Rio de Janeiro: IEEE, 2015. p. 1-4. ISBN 978-1-4673-7019-6. Disponível em: <http://ieeexplore.ieee.org/lpdocs/epic03/ wrapper.htm?arnumber $=7473600>$. Cited 2 times on pages 26 and 46.

Underwater soundscape of marine protected areas in the south Brazilian coast. Marine Pollution Bulletin, v. 105, n. 1, p. 65-72, apr 2016. ISSN 0025326X. Disponível em: <http://linkinghub.elsevier. com/retrieve/pii/S0025326X16301114>. Cited 9 times on pages 27, 47, 58, 66, 72, 73, 78, 79, and 84 .

Temporal and spectral patterns of fish choruses in two protected areas in southern atlantic. Ecological Informatics, p. -, 2017. ISSN 1574-9541. Disponível em: <//www.sciencedirect.com/science/article/ pii/S1574954117300274>. Cited 2 times on pages 27 and 78.

SANTOS, M. C. d. O.; SICILIANO, S.; VICENTE, A. F. d. C.; ALVARENGA, F. S.; ZAMPIROLLI, É.; SOUZA, S. P. D.; MARANHO, A. Cetacean records along São Paulo state coast, Southeastern Brazil. Brazilian Journal of Oceanography, v. 58, n. 2, p. 123-142, jun 2010. ISSN 1679-8759. Disponível em: $<$ http://www.scielo.br/scielo.php?pid=S1679-87592010000200004\{\&\}script=sci $\left\{\_\right\} \operatorname{arttext~}\{\&\}$ tlng= enhttp://www.scielo.br/scielo.php?script=sci $\left\{\_\right\} \operatorname{arttext}\{\&\}$ pid=S1679-87592010000200004\{\&\}lng=>. Cited on page 83.

SLABBEKOORN, H.; BOUTON, N.; OPZEELAND, I. van; COERS, A.; CATE, C. ten; POPPER, A. N. A noisy spring: the impact of globally rising underwater sound levels on fish. Trends in ecology \& evolution, Elsevier Ltd, v. 25, n. 7, p. 419-27, jul 2010. ISSN 0169-5347. Disponível em: <http: //www.ncbi.nlm.nih.gov/pubmed/20483503>. Cited 2 times on pages 51 and 65.

SMITH, S. W. The Scientist and Engineer's Guide to Digital Signal Processing. [s.n.], 1999. 650 p. ISSN 10512004. ISBN 0966017676. Disponível em: <www.DSPguide.com>. Cited 2 times on pages 59 and 72 .

SOARES, L. S. H.; VAZZOLER, A. E. A. d. M. Diel changes in food and feeding activity of sciaenid fishes from the South-western Atlantic, Brazil. Revista Brasileira de Biologia, v. 61, n. 2, p. 197-216, may 2001. ISSN 0034-7108. Disponível em: <http://www.scielo.br/scielo.php?script=sci $\left\{\_\right\} \operatorname{arttext}\{\&\}$ pid= S0034-71082001000200004 $\{\&\} \operatorname{lng}=\mathrm{en}\{\&\} \mathrm{nrm}>$. Cited on page 51 .

SOUTHALL, B. L.; BOWLES, A. E.; ELLISON, W. T.; FINNERAN, J. J.; GENTRY, R. L.; GREENE, C. R.; KASTAK, D.; KETTEN, D. R.; MILLER, J. H.; NACHTIGALL, P. E.; RICHARDSON, W. J.; THOMAS, J. a.; TYACK, P. L. Marine Mammal Noise Exposure Criteria: Initial Scientific Recommendations. Aquatic Mammals, v. 33, n. 4, p. 411-414, dec 2007. ISSN 01675427. Disponível em: <http://orton.catie.ac.cr/cgi-bin/wxis.exe/?IsisScript=SIBE01.xis $\{\&\}$ method=post $\{\&\}$ formato= $2\{\&\}$ cantidad $=1\{\&\}$ expresion $=\mathrm{mfn}=010033 \mathrm{http}: / / \mathrm{www}$.aquaticmammalsjournal.org/index.php? option=com $\left\{\backslash \_\right.$content $\{\&\}$ view=article $\{\&\}$ id=188:marine-mammal-noise-exposure-critehttp: $/ /$ www.aquaticmammalsjournal.org/index.php?option $=\operatorname{com}\left\{\backslash_{\_}\right\} \operatorname{content}\{\&\}$ view $=\operatorname{article}\{\&\}$ id=188: marine-mammal-noise-exposure-criteria-initial-scientific-recommendations $\{\&\}$ cati $>$. Cited 2 times on pages 31 and 38 .

SPRAGUE, M. W.; LUCZKOVICH, J. J.; PULLINGER, R. C.; JOHNSON, S. E.; JENKINS, T.; Daniel, Hal J., I. Using spectral analysis to identify drumming sounds of some North Carolina fishes in the family Sciaenidae. Journal of the Elisha Mitchell Scientific Society, v. 116, n. 2, p. 124-145, 2000. Cited on page 66. 
STAATERMAN, E.; PARIS, C.; DEFERRARI, H.; MANN, D.; RICE, A.; D’ALESSANDRO, E. Celestial patterns in marine soundscapes. Marine Ecology Progress Series, v. 508, p. 17-32, aug 2014. ISSN 0171-8630. Disponível em: <http://www.int-res.com/abstracts/meps/v508/p17-32/>. Cited 5 times on pages $25,72,73,75$, and 77 .

STAATERMAN, E.; RICE, A. N.; MANN, D. A.; PARIS, C. B. Soundscapes from a Tropical Eastern Pacific reef and a Caribbean Sea reef. Coral Reefs, v. 32, n. 2, p. 553-557, jun 2013. ISSN 0722-4028. Disponível em: <http://link.springer.com/10.1007/s00338-012-1007-8>. Cited 3 times on pages 45, 54, and 75.

SUEUR, J.; FARINA, A. Ecoacoustics: the Ecological Investigation and Interpretation of Environmental Sound. Biosemiotics, v. 8, n. 3, p. 493-502, dec 2015. ISSN 1875-1342. Disponível em: <http://link. springer.com/10.1007/s12304-015-9248- $x>$. Cited on page 25.

TASKER, M. L.; AMUNDIN, M.; ANDRE, M.; HAWKINS, A.; LANG, W.; MERCK, T.; THOMSEN, F.; WERNER, S.; ZAKHARIA, M.; REPORT, J. MARINE STRATEGY FRAMEWORK DIRECTIVE Task Group 11 Report Underwater noise and other forms of energy. [S.1.: s.n.], 2010. ISBN 9789279156540. Cited on page 45.

THOMSEN, F. Assessment of the environmental impact of underwater noise. OSPAR Commission. Biodiversity Series, v. 436, 2009. Cited on page 36.

TNO. Standard for measurement and monitoring of underwater noise, Part I: physical quantities and their units. [S.1.], 2011. Disponível em: <https://www.noordzeeloket.nl/images/ StandardformeasurementandmonitoringofunderwaternoisePartI $\left\{\_\right\} 648$.> Cited 3 times on pages 30, 31, and 32 .

TORRES, R. J.; ABESSA, D. M. S.; SANTOS, F. C.; MARANHO, L. A.; DAVANSO, M. B.; NASCIMENTO, M. R. L. do; MOZETO, A. A. Effects of dredging operations on sediment quality: contaminant mobilization in dredged sediments from the Port of Santos, SP, Brazil. Journal of Soils and Sediments, v. 9, n. 5, p. 420-432, oct 2009. ISSN 1439-0108. Disponível em: <http: //link.springer.com/10.1007/s11368-009-0121-x>. Cited on page 36.

TOWSEY, M.; PARSONS, S.; SUEUR, J. Ecology and acoustics at a large scale. Ecological Informatics, v. 21, p. 1-3, may 2014. ISSN 15749541. Disponível em: <http://linkinghub.elsevier.com/retrieve/pii/ S1574954114000181>. Cited 2 times on pages 25 and 70.

TOWSEY, M.; WIMMER, J.; WILLIAMSON, I.; ROE, P. The use of acoustic indices to determine avian species richness in audio-recordings of the environment. Ecological Informatics, Elsevier B.V., v. 21, n. 100, p. 110-119, may 2014. ISSN 15749541. Disponível em: <http://dx.doi.org/10.1016/j.ecoinf. 2013.11.007http://linkinghub.elsevier.com/retrieve/pii/S1574954113001209>. Cited 2 times on pages 25 and 70 .

TOWSEY, M.; ZHANG, L.; COTTMAN-FIELDS, M.; WIMMER, J.; ZHANG, J.; ROE, P. Visualization of Long-duration Acoustic Recordings of the Environment. Procedia Computer Science, v. 29, p. 703-712, 2014. ISSN 18770509. Disponível em: <http://linkinghub.elsevier.com/retrieve/pii/ S1877050914002403>. Cited 4 times on pages 25, 70, 72, and 79.

VASCONCELOS, R. O.; AMORIM, M. C. P.; LADICH, F. Effects of ship noise on the detectability of communication signals in the Lusitanian toadfish. Journal of Experimental Biology, v. 210, n. 12, p. 2104-2112, jun 2007. ISSN 0022-0949. Disponível em: <http://jeb.biologists.org/cgi/doi/10.1242/jeb. 004317>. Cited on page 38 .

Velleman, P. F.; HOAGLin, D. C. Applications, Basics, and Computing of Exploratory Data Analysis. [S.1.: s.n.], 1981. Cited on page 32. 
VERFUSS, U.; ANDERSSON, M.; FOLEGOT, T.; LAANEARU, J.; MATUSCHEK, R.; PAJALA, J.; SIGRAY, P.; TEGOWSKI, J.; TOUGAARD, J. BIAS Standards for noise measurements. Background information, Guidelines and Quality Assurance. [S.1.], 2014. Disponível em: $<$ http://ec.europa.eu/environment/life/project/Projects/index.cfm?fuseaction=home.showFile $\{\&\} \mathrm{rep}=$ file $\{\&\}$ fil $=$ BIAS $\left\{\_\right\}$standards $>$. Cited on page 62 .

VIEIRA, M.; FONSECA, P. J.; AMORIM, M. C. P.; TEIXEIRA, C. J. Call recognition and individual identification of fish vocalizations based on automatic speech recognition: An example with the Lusitanian toadfish. The Journal of the Acoustical Society of America, v. 138, n. 6, p. 3941-3950, dec 2015. ISSN 0001-4966. Disponível em: <http://scitation.aip.org/content/asa/journal/jasa/138/6/10.1121/1.4936858>. Cited on page 67.

WARE, K. Opsar assessment of the impacts of shipping on the marine environment. Monitoring and Assessment Series: OSPAR Commission, 2009. Cited 2 times on pages 36 and 45.

WELCH, P. The use of fast Fourier transform for the estimation of power spectra: A method based on time averaging over short, modified periodograms. IEEE Transactions on Audio and Electroacoustics, v. 15, n. 2, p. 70-73, jun 1967. ISSN 0018-9278. Disponível em: <http://ieeexplore.ieee.org/lpdocs/epic03/ wrapper.htm?arnumber=1161901>. Cited 2 times on pages 31 and 72 .

ZHDANOVA, I. V.; REEBS, S. G. Circadian Rhythms in Fish. In: . [s.n.], 2005. p. 197-238. Disponível em: <http://linkinghub.elsevier.com/retrieve/pii/S1546509805240062>. Cited on page 81.

ZIMMER, W. M. X. Passive Acoustic Monitoring of cetaceans. [S.1.: s.n.], 2011. 366 p. ISBN 9780521193429. Cited on page 83. 